HELOISE BALHESTEROS

\title{
CARACTERIZAÇÃO DO PAPEL DE DOIS FATORES SIGMA DE FUNÇÃO EXTRACITOPLASMÁTICA DA FAMÍLIA FecI \\ EM Caulobacter crescentus
}

Tese apresentada ao Programa de PósGraduação em Microbiologia do Instituto de Ciências Biomédicas da Universidade de São Paulo, para obtenção de Título de Doutora em Ciências. 


\author{
HELOISE BALHESTEROS
}

\title{
CARACTERIZAÇÃO DO PAPEL DE DOIS FATORES SIGMA DE FUNÇÃO EXTRACITOPLASMÁTICA DA FAMÍLIA FecI \\ EM Caulobacter crescentus
}

\begin{abstract}
Tese apresentada ao Programa de PósGraduação em Microbiologia do Instituto de Ciências Biomédicas da Universidade de São Paulo, para obtenção de Título de Doutora em Ciências.
\end{abstract}

Área de concentração: Microbiologia

Orientadora: Profa. Dra. Marilis do Valle Marques

Versão original 
DADOS DE CATALOGAÇÃO NA PUBLICAÇÃO (CIP)

Serviço de Biblioteca e Informação Biomédica do

Instituto de Ciências Biomédicas da Universidade de São Paulo

reprodução não autorizada pelo autor

Balhesteros, Heloise.

Caracterização do papel de dois fatores sigma de função extracitoplasmática da família Fecl em Caulobacter crescentus / Heloise Balhesteros. -- São Paulo, 2014.

Orientador: Profa. Dra. Marilis do Valle Marques.

Tese (Doutorado) - Universidade de São Paulo. Instituto de Ciências Biomédicas. Departamento de Microbiologia. Área de concentração: Microbiologia. Linha de pesquisa: Regulação gênica de microorganismo.

Versão do título para o inglês: Characterization of the role of two Fecl-like extracytoplasmic function sigma factors in Caulobacter crescentus.

1. Microbiologia 2. Biologia molecular 3. Regulação gênica 4. Fatores sigma de carência de ferro 5. Caulobacter crescentus I. Marques,Profa. Dra. Marilis do Valle II. Universidade de São Paulo. Instituto de Ciências Biomédicas. Programa de Pós-Graduação em Microbiologia III. Título. 


\section{UNIVERSIDADE DE SÃO PAULO \\ INSTITUTO DE CIÊNCIAS BIOMÉDICAS}

Candidato(a): Heloise Balhesteros.

Título da Tese: $\quad$ Caracterização do papel de dois fatores sigma de função extracitoplasmática da família Fecl em Caulobacter crescentus.

Orientador(a): $\quad$ Profa. Dra. Marilis do Valle Marques.

A Comissão Julgadora dos trabalhos de Defesa da Tese de Doutorado, em sessão pública realizada a .................., considerou

( ) Aprovado(a)

( ) Reprovado(a)

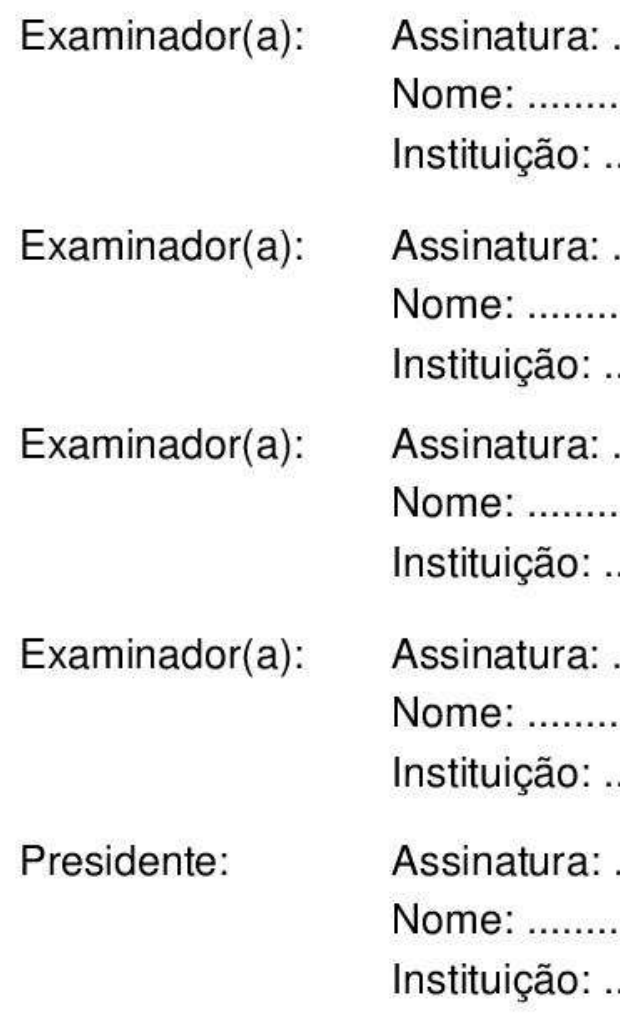




\section{CERTIFICADO DE ISENÇÃO}

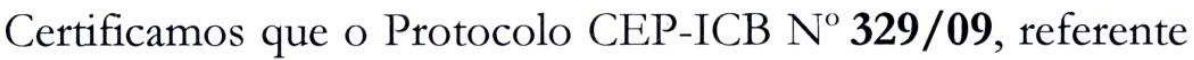
ao projeto intitulado: "Caracterização de fatores sigma de função extracitoplasmática envolvidos na resposta a carência de ferro em Caulobacter crescentus" sob a responsabilidade de Heloise Balhesteros, foi analisado na presente data pela CEEA - COMISSÃo DE ÉTICA EM EXPERIMENTAÇÃO ANIMAL e pela CEPSH - COMISSÃO DE ÉTICA EM PESQUISA COM SERES HUMANOS, tendo sido deliberado que o referido projeto não envolve manipulação animal ou humana que justifique uma aprovação quanto aos princípios éticos exigidos por ambas as Comissões.

São Paulo, 18 de agosto de 2009.

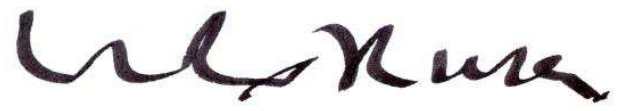

PROF. DR. WOTHAN TAVARES DE LIMA Coordenador da CEEA - ICB/USP

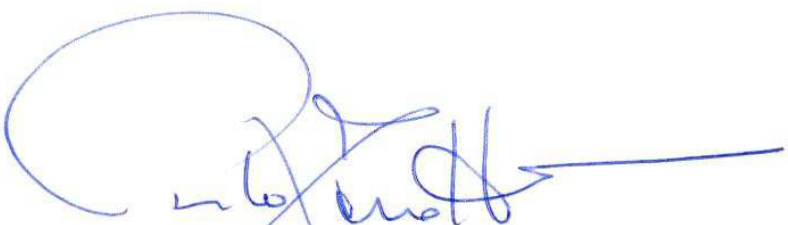

PROF. Dr, PAOLO M.A ZaNOTTO Vice-Coordenador da CEPsh - ICB/USP 


\section{AGRADECIMENTOS}

À Profa. Dra. Marilis do Valle Marques pela orientação, pela dedicação a seus alunos e pelas discussões enriquecedoras.

Aos professores Dr. Phillip Klebba e Dra. Salete Newton pela inestimável orientação durante meu período Sanduíche em seu laboratório. Aos colegas Aritri, Lorne, Mathew, Noah e Yan, por me acolherem de braços abertos e pelo aprendizado que me proporcionaram.

Aos colegas de laboratório Alexandre, Angel, Carolina, Ivan, Juliana, Ricardo e Rodolfo, e aos ex-colegas André, Daniela, Elza, Émerson, Gabriela, João, José, Letícia, Lígia, Maristela, Mirian, Rafael, Vânia, Valéria Italiani, Valéria Karla, Ynés e Zuleta, por tudo que me ensinaram e pelo bom convívio, seja ao longo de vários anos, seja por um pequeno período, mas sempre tendo me influenciado positivamente.

Aos componentes da banca de Qualificação pelas sugestões.

Aos professores, funcionários e colegas do Departamento de Microbiologia.

Aos professores Dra. Regina Lúcia Baldini, Dr. Rodrigo da Silva Galhardo e Dra. Suely Lopes Gomes, por permitirem a utilização das dependências de seus laboratórios e equipamentos em várias ocasiões.

Ao Dr. Michael T. Laub, pelo fornecimento das lâminas de microarranjos de cDNA para Caulobacter crescentus, e às professoras Dra. Carla Rosenberg e Dra. Andréa Fogaça e respectivos membros do laboratório, pela ajuda na execução destes experimentos. Ao Dr. Rogério Ferreira Lourenço pelo auxílio na análise dos resultados.

À FAPESP pelo auxílio financeiro.

Às secretárias Elizabete, Gisele e Naíde pela ajuda sempre que foram solicitadas.

À minha mãe, Rosa Maria, pelo apoio, compreensão, amor e pelos valores transmitidos a mim.

Ao meu noivo Sergio, pela cumplicidade, compreensão, afeto, empatia e por tornar meus dias mais felizes a seu lado. 
"Yeah, Mr. White! Yeah, science!" Jesse Pinkman 


\section{RESUMO}

\section{BALHESTEROS, H. Caracterização do papel de dois fatores sigma de função}

extracitoplasmática da família FecI em Caulobacter crescentus. 2014. 110 f. Tese (Doutorado em Microbiologia) - Instituto de Ciências Biomédicas, Universidade de São Paulo, São Paulo, 2014.

O ferro é um micronutriente essencial para a maioria dos organismos, participando da estrutura de diversas proteínas importantes para o metabolismo energético. As bactérias desenvolveram vários mecanismos específicos para sua captação, dentre eles a secreção de quelantes orgânicos de ferro (sideróforos) e a regulação gênica de acordo com a disponibilidade de ferro no ambiente. Parte dessa regulação gênica é realizada por fatores sigma específicos, denominados fatores sigma de carência de ferro, que se ligam ao cerne da RNA polimerase para transcrever genes de transporte ou biossíntese de sideróforos e cujo modelo é FecI de Escherichia coli. Geralmente, estes fatores sigma estão sujeitos a regulação pós-traducional por fatores antissigma (FecR em E. coli) e transcricional por Fur, um repressor de genes envolvidos na captação de ferro e que utiliza $\mathrm{Fe}^{2+}$ como co-repressor e sinalizador da disponibilidade deste metal. A $\alpha$-proteobactéria de vida livre Caulobacter crescentus possui em seu genoma quatro genes codificando fatores sigma da família FecI. Contrariamente ao modelo observado em outras bactérias, não há sítios de ligação de Fur nas regiões regulatórias destes genes. Este trabalho buscou verificar se há envolvimento destes fatores sigma na regulação da captação de ferro nesta bactéria. A correlação entre a disponibilidade de ferro e a expressão destes genes foi investigada por ensaios de atividade de $\beta$-galactosidase, que revelaram a ausência de indução significativa destes genes em carência de ferro ou na linhagem mutante para fur, indicando que eles não são diretamente regulados pela disponibilidade de ferro ou por Fur. Foram estudados de modo mais aprofundado dois sistemas do tipo FecI de C. crescentus, cada um consistindo de genes ortólogos a fecI, fecR e $f e c A$ (este último codificando um receptor de membrana externa sinalizador da presença de sideróforo). Linhagens mutantes para os genes fecA2, fecR2, fecI4 e fecR4 mostraram curvas de crescimento similares à da linhagem parental, tanto em carência de ferro como em presença de diferentes fontes de ferro. Análises por microarranjos de DNA revelaram que apenas o gene $f e c A 2$ é induzido no mutante $\Delta f e c R 2$ em comparação à linhagem parental, sugerindo que este é o único gene alvo do fator sigma FecI2, que se supõe estar constitutivamente ativado na linhagem $\Delta f e c R 2$. Já a linhagem $\Delta f e c R 4$ mostrou indução em mais de 50 genes, incluindo genes codificando enzimas envolvidas no metabolismo e biossíntese de aminoácidos e utilização de fontes alternativas de carbono. Microarranjos fenotípicos com o mutante $\Delta f e c I 4$ indicaram que este gene pode ser importante para o crescimento em $\gamma$-ciclodextrina ou ácido caproico como fonte de carbono. Os resultados sugerem que os dois fatores sigma estudados controlam diferentes conjuntos de genes, sendo o fator sigma FecI2 bem específico, enquanto FecI4 parece regular uma resposta mais geral relacionada a compostos carbônicos, e não relacionada à homeostase de ferro.

Palavras-chave: Microbiologia. Biologia molecular. Regulação gênica. Fatores sigma de carência de ferro. Caulobacter crescentus. 


\begin{abstract}
BALHESTEROS, H. Characterization of the role of two FecI-like extracytoplasmic function sigma factors in Caulobacter crescentus. 2014. $110 \mathrm{f}$. Ph. D. thesis (Microbiology) - Instituto de Ciências Biomédicas, Universidade de São Paulo, São Paulo, 2014.

Iron is an essential micronutrient for most organisms, participating on the structure of many proteins that are important for energetic metabolism. Mechanisms employed by bacteria for iron uptake include secretion of iron chelators (siderophores) and gene regulation according to iron availability in the environment. Part of this gene regulation is accomplished by iron starvation sigma factors, represented by FecI from Escherichia coli, which bind to RNA polymerase core to transcribe genes for siderophore transport or biosynthesis. These sigma factors usually display post-translational regulation by anti-sigma factors (FecR in E. coli) and transcriptional regulation by Fur, a repressor of genes involved in iron uptake, which utilizes $\mathrm{Fe}^{2+}$ as a co-repressor signaling for iron availability. The genome of the freeliving, $\alpha$-proteobacterium Caulobacter crescentus possesses four genes encoding putative iron starvation sigma factors. Contrary to the observed in other bacteria, there are no Fur-binding sites in the regulatory regions of these genes. This work aimed to verify whether these sigma factors are involved in iron uptake regulation in this bacterium. Correlation between iron availability and gene expression was assessed by $\beta$-galactosidase activity assays, which revealed the absence of significant induction of these genes under iron starvation or in the $\Delta$ fur mutant strain, suggesting that they are not directly regulated by iron availability or Fur. Two of the FecI-like systems in $C$. crescentus were studied more thoroughly, each one consisting of orthologs of $f e c I, f e c R$ and $f e c A$ (the latter encoding an outer membrane receptor which signals for the presence of siderophore). Mutant strains for genes fecA2, fecR2, fecI and $f e c R 4$ showed growth curves similar to the parental strain, either under iron starvation or in the presence of different iron sources. cDNA microarray analyses revealed that $f e c A 2$ is the only gene induced in the $\Delta f e c R 2$ strain compared to the wild-type, suggesting that this is the only target gene for FecI2, which was assumed to be constitutively activated in $\Delta f e c R 2$. The $\Delta f e c R 4$ strain, however, showed induction in more than 50 genes, including genes encoding enzymes involved in amino acid metabolism and biosynthesis and alternative carbon sources utilization. Phenotypic microarrays with $\Delta f e c I 4$ showed that this gene is important for growth in $\gamma$-cyclodextrin or caproic acid as the sole carbon source. The results suggest that the two sigma factors analyzed control different sets of genes, being the FecI2 sigma factor-mediated response very specific, whereas FecI4 seems to regulate a more general response, related to carbon compounds rather than iron homeostasis.
\end{abstract}

Keywords: Microbiology. Molecular biology. Gene regulation. Iron starvation sigma factors. Caulobacter crescentus. 


\section{LISTA DE ILUSTRAÇÕES}

Figura 1 - Representação esquemática do ciclo celular de Caulobacter crescentus ........ 16

Figura 2 - Sistemas de captação de ferro em bactérias Gram-negativas

Figura 3 - Representação esquemática do sistema de captação de ferro mediada por sideróforos em bactérias Gram-negativas 23

Figura 4 - Organização estrutural de sistemas regulatórios dependentes de TonB 27

Figura 5 - Organização gênica e aspectos evolutivos dos sistemas de sinalização de superfície regulados por ferro em Pseudomonas aeruginosa e Caulobacter crescentus

Figura 6 - Representação esquemática das regiões do genoma de Caulobacter crescentus NA1000 analisadas neste trabalho

Figura 7 - Expressão derivada dos promotores à frente de genes codificando fatores sigma do tipo FecI em $C$. crescentus 46

Figura 8 - Análise da expressão dos promotores PtonB sob excesso ou carência de ferro

Figura 9 - Análise de expressão dos promotores na presença do sideróforo ferricromo

Figura 10 - Expressão de promotores PtonB em linhagens mutantes para o anti-sigma correspondente.

Figura 11 - Verificação da ocorrência de autorregulação dos fatores sigma FecI2 e FecI4

Figura 12 - Curvas de crescimento de $\Delta f e c R 2$ e $\Delta f e c R 4$ em meio PYE 55

Figura 13 - Curvas de crescimento de $\Delta f e c R 2$ e $\Delta f e c R 4$ em meio mínimo M2 ............... 57

Figura 14 - Ensaio de sensibilidade a peróxido de hidrogênio....................................... 58

Figura 15 - Curvas de crescimento dos mutantes $\Delta f e c A 2$ e $\Delta f e c I 4$ em meio PYE ......... 59

Figura 16 - Curvas de crescimento de $\Delta f e c A 2$ e $\Delta f e c I 4$ em meio mínimo M2 ................. 60

Figura 17 - Curvas de crescimento de NA1000 na presença de quelantes de ferro ou ferricromo.

Figura 18 - Teste de utilização de sideróforos utilizando 2,2'-dipiridil como quelante de ferro.

Figura 19 - Comparação entre testes de utilização de sideróforos com diferentes quelantes de ferro

Figura 20 - Utilização de sideróforos por $C$. crescentus NA1000 66 


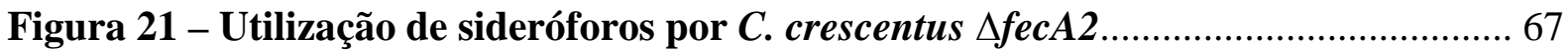

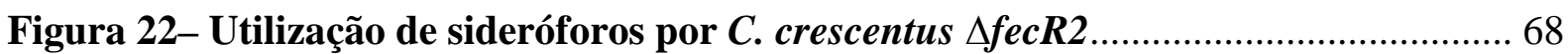

Figura 23 - Utilização de sideróforos por $C$. crescentus $\Delta$ fecI4 .................................... 69

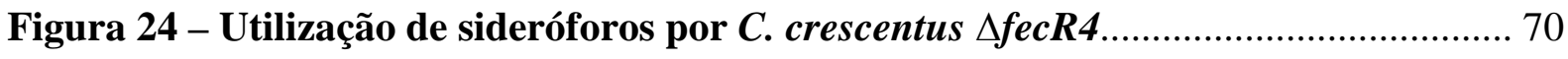

Figura 25 - Design do experimento de microarranjo de cDNA …............................... 73

Figura 26 - Provável sequência promotora reconhecida pelo fator sigma FecI4 .......... 85

Figura 27 - Representação esquemática do perfil de crescimento observado em

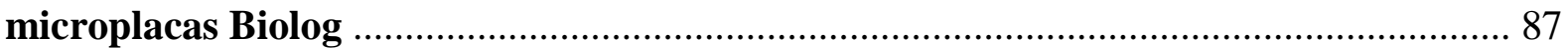

Figura 28 - Análise do crescimento de NA1000 e $\Delta f e c I 4$ em microarranjos fenotípicos 96

Figura 29 - Estrutura de compostos carbônicos possivelmente envolvidos na via

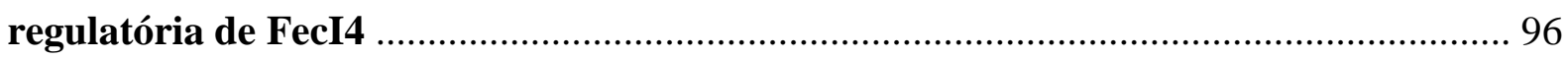

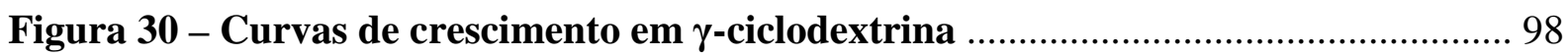




\section{LISTA DE TABELAS}

Tabela 1. Linhagens bacterianas utilizadas neste trabalho ......................................... 32

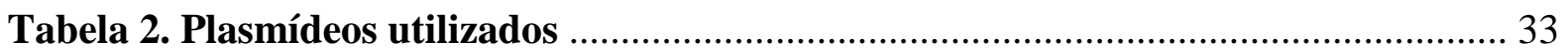

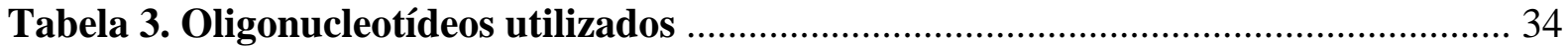

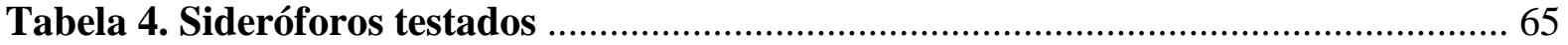

Tabela 5. Diâmetros de halos de crescimento $(\mathrm{em} \mathrm{cm})$ para cada linhagem de $C$. crescentus em testes de utilização de sideróforos

Tabela 6. Genes induzidos na linhagem $\Delta f e c R 4$ observados na análise de microarranjos

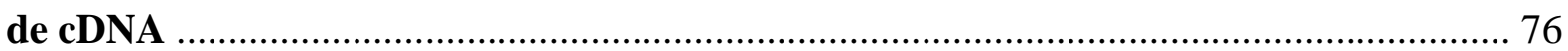

Tabela 7. Expressão relativa de genes por RT-PCR quantitativo …............................ 82

Tabela 8. Perfil de crescimento de $C$. crescentus em microplacas Biolog PM1 .............. 88

Tabela 9. Perfil de crescimento de $C$. crescentus em microplacas Biolog PM2A ........... 92 
ABC: ATP-binding cassette

Ap: ampicilina

ApoEnt: apo-enterobactina

ATP: adenosina trifosfato

BP: 2,2'-dipiridil

cDNA: DNA complementar

Da: dalton(s)

dATP: desoxiadenosina trifosfato

DDP: 2,2'-dipiridil

DNA: ácido desoxirribonucléico

DNAse: desoxirribonuclease

dNTPs: desoxirribonucleotídeos fosfatados

$\mathrm{DO}_{600}$ : densidade óptica a 600 nanômetros

ECF: função extracitoplasmática

Ent: enterobactina

FAD: flavina adenina dinucleotídeo

Fc: ferricromo

$\mathrm{gCD}: \gamma$-ciclodextrina

kb: quilobase(s)

$\mathrm{Km}$ : canamicina

LB: Luria-Bertani

M: molar

MEME: Multiple Em for Motif Elicitation

mRNA: RNA mensageiro

mut.: mutante

NAD: nicotinamida adenina dinucleotídeo (oxidado)

NADH: nicotinamida adenina dinucleotídeo (reduzido)

NADP: nicotinamida adenina dinucleotídeo fosfato

NB: nutrient broth (caldo nutriente)

ND: não determinado

nt: nucleotídeo(s)

ORF: open reading frame (quadro aberto de leitura) 
pb: pares de bases

PCR: reação em cadeia da polimerase

qRT-PCR: reação em cadeia da polimerase em tempo real quantitativa RNA: ácido ribonucléico

rpm: rotações por minuto

RSAT: Regulatory Sequence Analysis Tools

sRNA: pequeno RNA

Tc: tetraciclina

TSS: transcription start site (sítio de início da transcrição)

$\mathrm{U}$ : unidade(s)

$\gamma$-CD: $\gamma$-ciclodextrina 


\section{SUMÁRIO}

1 INTRODUÇÃO E REVISÃO DE LITERATURA ….............................................. 15

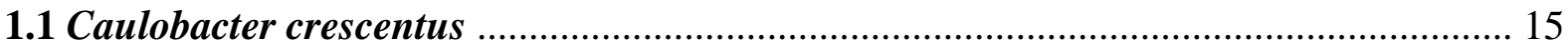

1.2 Captação do ferro e sua importância em bactérias ................................................ 20

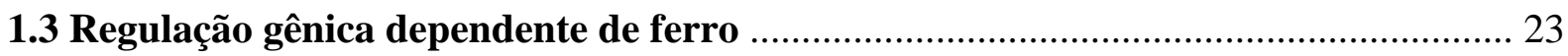

1.4 Homeostase de ferro em Caulobacter crescentus e genes relacionados .................... 28

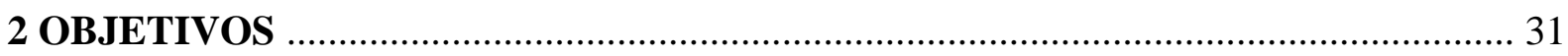

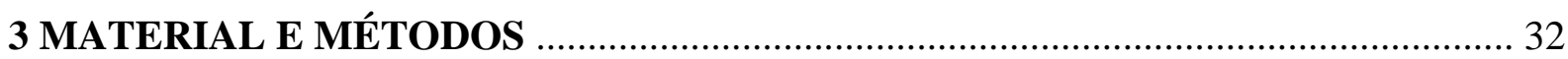

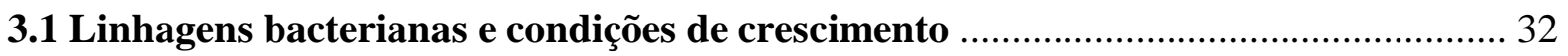

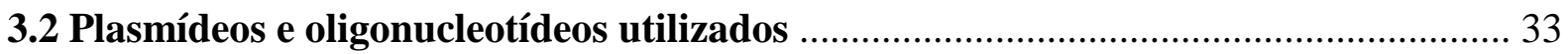

3.3 Construção de fusões transcricionais e ensaio de atividade de $\beta$-galactosidase ........ 36

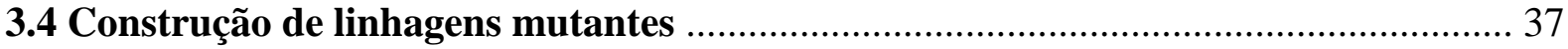

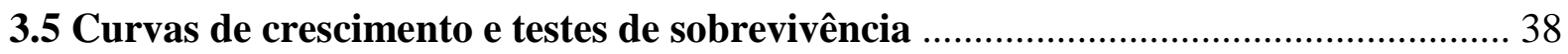

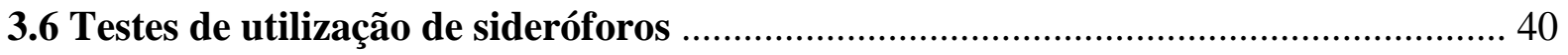

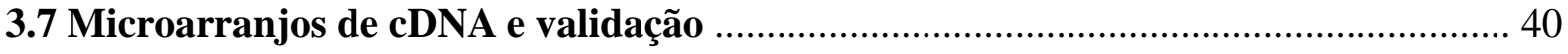

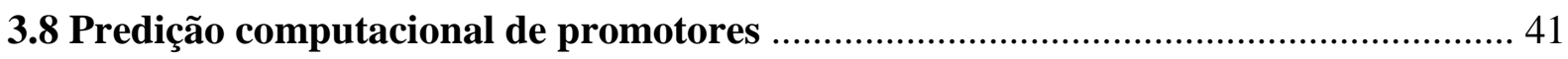

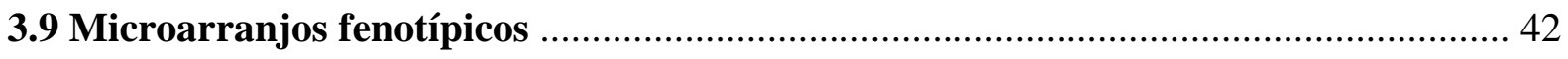

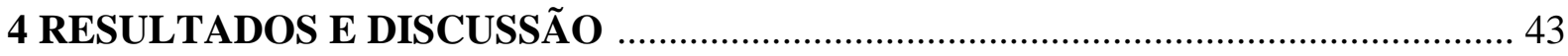

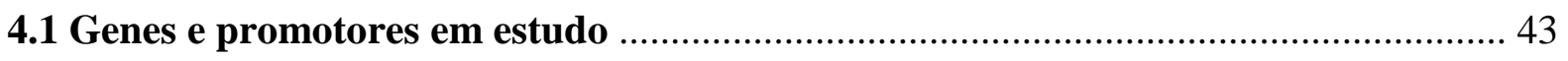

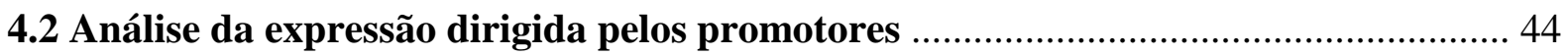

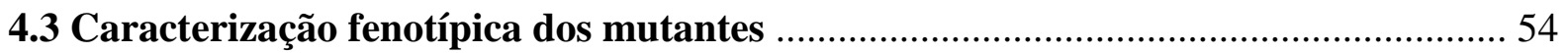

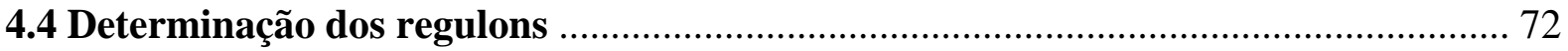

4.5 Estudo das fontes de carbono utilizadas por $C$. crescentus ...................................... 86

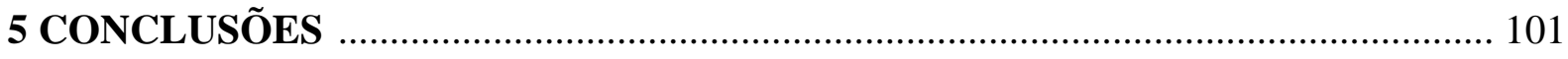

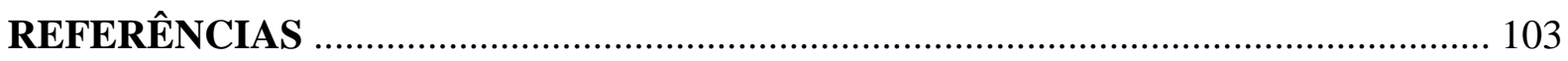




\section{INTRODUÇÃO E REVISÃO DE LITERATURA}

\subsection{Caulobacter crescentus}

O conceito de diferenciação celular não é normalmente associado a organismos procarióticos, mas sim a organismos pluricelulares. Contudo, este tipo de desenvolvimento também é observado em algumas espécies bacterianas, constituindo um processo altamente organizado em nível molecular. O entendimento deste conceito de desenvolvimento bacteriano vem sendo aperfeiçoado através de análises citológicas e genômicas utilizando diversos organismos modelo, como Bacillus subtilis, Caulobacter crescentus, Myxococcus xanthus e Streptomyces sp., tendo como objeto de estudo processos como esporulação, comportamento multicelular e ciclo celular bacteriano (FIGGE; GOBER, 2003).

Em todos os organismos, o ciclo celular progride através de quatro processos: replicação do DNA, segregação dos cromossomos, divisão celular e crescimento celular. Caulobacter crescentus é considerada a espécie bacteriana modelo para o estudo do ciclo celular em procariotos e sua regulação. Estes estudos têm permitido o entendimento cada vez mais detalhado dos mecanismos moleculares para a geração e manutenção da assimetria espacial da célula bacteriana durante seu ciclo celular (DAVIS; WALDOR, 2013; LALOUX; JACOBS-WAGNER, 2014).

C. crescentus é uma bactéria oligotrófica, aquática e de vida livre pertencente ao grupo das $\alpha$-proteobactérias. Seu ciclo celular com diferenciação é caracterizado pela produção de duas células filhas distintas a cada divisão: uma célula-talo e uma célula flagelada. A célulatalo é caracterizada por uma extensão do envelope celular, o talo, que possui em sua extremidade um polissacarídeo adesivo, permitindo a fixação da célula a superfícies. Já a célula flagelada não possui talo e é móvel, possuindo um único flagelo, além de pili e aparato quimiotático, ao contrário da célula-talo. As diferenças entre os tipos celulares não são apenas morfológicas: a célula-talo é capaz de reiniciar a replicação do cromossomo e a divisão celular assim que é formada; o mesmo não pode ser dito da célula flagelada. Nesta, a replicação do cromossomo se encontra silenciada, correspondendo à fase G1 do ciclo celular

(Fig. 1). É necessário que a célula flagelada se diferencie em uma célula-talo para que a replicação possa ocorrer. Para isso, há perda do flagelo, retração dos pili, degradação do aparato quimiotático e síntese de um talo no mesmo polo onde se encontrava o flagelo (SKERKER; LAUB, 2004; TSOKOS; LAUB, 2012; VIOLLIER; SHAPIRO, 2004). 

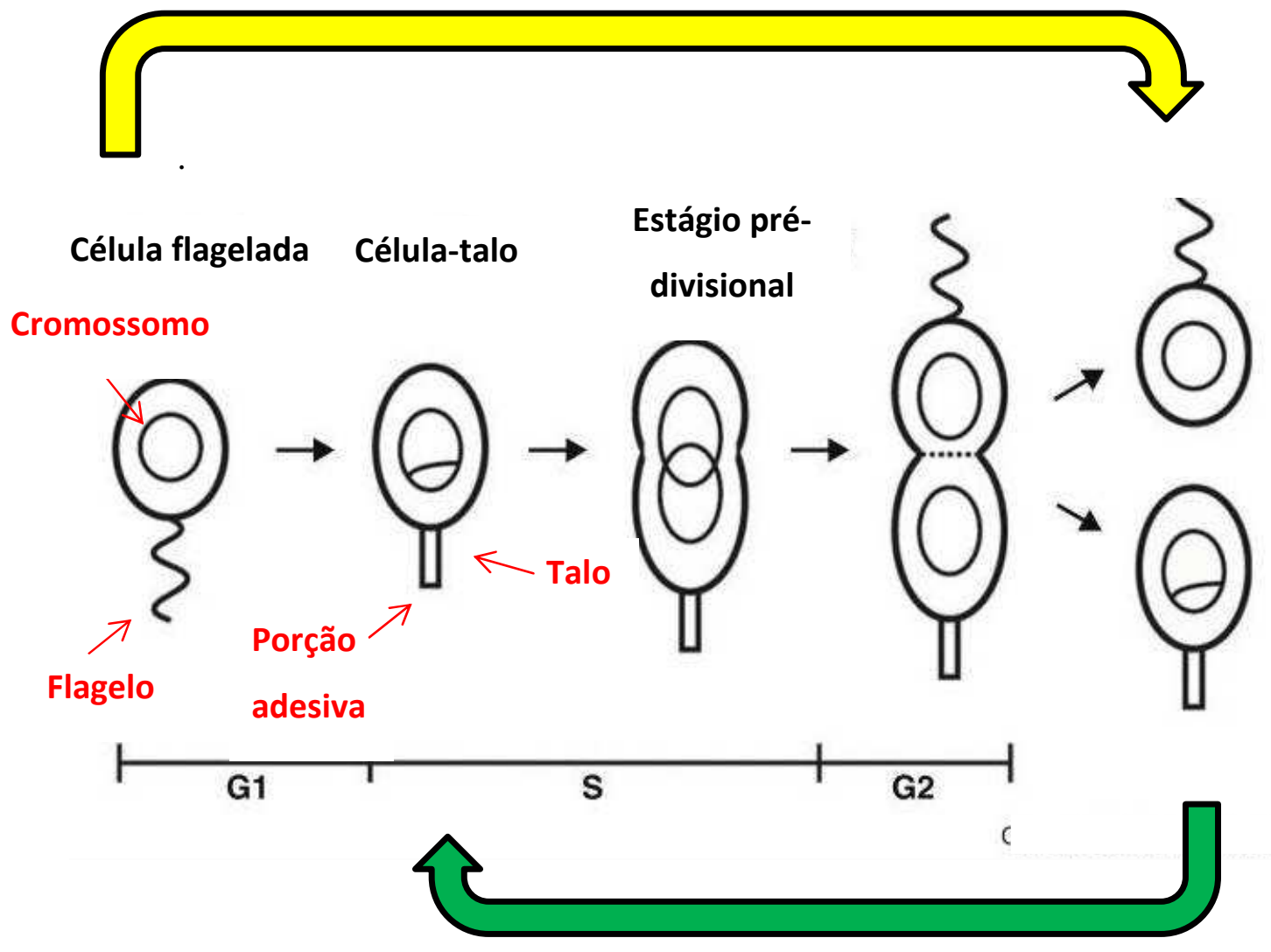

Figura 1 - Representação esquemática do ciclo celular de Caulobacter crescentus. Estágios morfológicos aparecem indicados acima do diagrama, e estágios de divisão celular (G1, S e G2), abaixo dele. A fase G1 corresponde à célula flagelada e precede a fase de replicação do DNA (fase $S$ ). Durante a fase $S$, a célula móvel perde o flagelo e um talo é formado no mesmo polo. Inicia-se então a fase G2, levando à citocinese e formação de duas células filhas distintas. Indicadas em vermelho, estão algumas estruturas morfológicas das células de $C$. crescentus. O cromossomo é representado como um círculo dentro das células, e círculos interligados representam cromossomos em processo de replicação. A seta amarela indica o retorno da célula flagelada ao ciclo; a seta verde indica o mesmo para a célula-talo.

FONTE: Modificado de Tsokos e Laub (2012).

Com a diferenciação da célula flagelada em célula-talo, tem início a replicação do material genético e o aumento de tamanho da célula (fase S) (Fig. 1). No estágio prédivisional, há a formação de um flagelo no polo oposto ao talo, que culminará na formação de uma nova célula móvel nesta extremidade. Cada célula filha recebe uma cópia do cromossomo, forma-se o septo e as células finalmente se dividem (fase G2) (SKERKER; LAUB, 2004; TSOKOS; LAUB, 2012; VIOLLIER; SHAPIRO, 2004). A heterogeneidade observada na célula pré-divisional decorre de um processo complexo, dependente do acúmulo de diferentes fatores determinantes do desenvolvimento de cada tipo celular (JUDD et al., 2003; KIEKEBUSCH; THANBICHLER, 2014). 
Apesar de $C$. crescentus ser um modelo muito estudado de diferenciação celular em bactérias, esta não é a única espécie a apresentar esta característica. Bacillus subtilis apresenta divisão assimétrica quando sujeita a certas condições de carência nutricional, culminando na produção de um esporo (SHAPIRO; MCADAMS; LOSICK, 2002). A assimetria em outras bactérias é mais facilmente observada quando envolve o posicionamento de estruturas de superfície, como flagelos, pili e talos, e estruturas sensoras, como quimiorreceptores. Bactérias como Escherichia coli, Pseudomonas aeruginosa, Shigella flexneri e Listeria monocytogenes também possuem polos assimétricos, apesar da aparente morfologia simétrica (SHAPIRO; MCADAMS; LOSICK, 2002). Um exemplo de assimetria funcional é apresentado por Bradyrhizobium, pois um de seus polos (o polo antigo, em oposição ao polo novo resultante da divisão celular) é preferencialmente utilizado para adesão às raízes de plantas hospedeiras (LOH et al., 1993). Os patógenos intracelulares de mamíferos S. flexneri e L. monocytogenes têm filamentos de actina do hospedeiro agregados em um dos polos, formando uma estrutura motora unidirecional para penetração em células vizinhas (GOLDBERG et al., 1993; SMITH; PORTNOY; THERIOT, 1995).

Uma questão que surge ao se tomar conhecimento do ciclo celular de C. crescentus é sua relevância in vivo. Acredita-se que a diferenciação celular desta bactéria seja importante para a adaptação às condições ambientais. Os ambientes aquáticos e úmidos em que $C$. crescentus vive apresentam dinamismo e instabilidade, sendo necessária a rápida adaptação a condições adversas. Isto se dá através da transdução de sinais ambientais até o interior da célula, onde ocorre a expressão diferenciada de genes para gerar uma resposta celular adequada à situação em questão. Em $C$. crescentus, a transdução de sinais ocorre não apenas nestas condições, mas também no próprio programa de desenvolvimento celular (JENAL, 2000; TSOKOS; LAUB, 2012). Muitos sistemas de organização interna de C. crescentus apresentam localização específica dentro da célula, indicando que há uma conexão direta entre o desenvolvimento e a morfogênese polar. Argumenta-se que o dimorfismo celular de $C$. crescentus seja uma vantagem adaptativa, na medida em que há a exploração de nichos mais favoráveis pela forma flagelada e a colonização deste pela forma séssil replicativa (HALLEZ et al., 2004), caracterizando, portanto, uma relação entre a percepção das condições ambientais, diferenciação celular e adaptação ao ambiente.

C. crescentus habita ambientes aquáticos com concentrações na faixa de micromolar de macronutrientes como carbono, nitrogênio e fósforo (ENGLAND et al., 2010). Como $C$. crescentus habita ambientes pobres em nutrientes, esta espécie sofre constantemente com carência nutricional. Para lidar com isso, várias adaptações promovem sua sobrevivência 
neste tipo de habitat: o talo com a porção adesiva, que facilita a adesão a superfícies contendo fontes nutricionais; o ciclo celular dimórfico, que permite a separação das funções de crescimento celular e de procura por nutrientes; e uma ampla gama de sensores ambientais e sistemas regulatórios (BOUTTE; CROSSON, 2013). A irreversibilidade da diferenciação da célula móvel em célula-talo indica que fatores ambientais como a disponibilidade de nutrientes para reprodução celular têm influência no momento do abandono da motilidade para início de um estilo de vida séssil .

Os mecanismos para a progressão do ciclo celular em C. crescentus são complexos e variados, muitos deles se utilizando de sistemas de dois componentes (JENAL, 2000; TSOKOS; LAUB, 2012). Basicamente, estes sistemas consistem de um par específico de proteínas: um sensor, frequentemente localizado na membrana citoplasmática, que monitora algum parâmetro ambiental; e um regulador de resposta citoplasmático, que gera uma resposta adaptativa através da expressão seletiva de genes. A comunicação entre as duas proteínas se dá através da transferência de fosfato. Com atividade de autoquinase, os sensores ligam um grupo fosfato do ATP a um de seus resíduos de histidina quando há o estímulo ambiental apropriado. Ocorre, então, a transferência do fosfato do sensor para um resíduo de aspartato do regulador de resposta, que irá dirigir a transcrição de genes específicos para a condição ambiental em questão (JUNG et al., 2012).

Uma família de proteínas regulatórias controla a progressão do ciclo celular de $C$. crescentus. Vários eventos importantes para o ciclo celular, como o silenciamento da origem de replicação, metilação do DNA, inibição da divisão celular e biossíntese do flagelo, são controlados pelo regulador de resposta CtrA (KIEKEBUSCH; THANBICHLER, 2014). CtrA encontra-se ativo em células móveis, explicando a impossibilidade deste tipo celular de iniciar a replicação do DNA e, consequentemente, o ciclo celular. A atividade de CtrA não só é específica de um dos tipos celulares, como também está sujeita a um controle temporal e espacial mediado por diversas outras proteínas, que irão atuar através de regulação da transcrição, fosforilação e degradação proteica (KIRKPATRICK; VIOLLIER, 2012). Além de CtrA, existe outro regulador global, GcrA, que regula a expressão de fatores necessários para a replicação do DNA e transformação de células flageladas em células-talo (HOLTZENDORFF et al., 2004). CtrA e GcrA formam um circuito genético oscilatório, com CtrA exercendo controle negativo sobre a expressão de GcrA; GcrA, por sua vez, ativa CtrA (HOLTZENDORFF et al., 2004).

CtrA e GcrA são apenas dois dos múltiplos fatores que atuam no controle da progressão do ciclo celular de C. crescentus. Muitas das proteínas regulatórias do ciclo fazem 
parte de sistemas de dois componentes; exemplos incluem DivJ/DivK, CckA, FlbE/FlbD, PleC/PleD, entre outras (JENAL, 2000; KIRKPATRICK; VIOLLIER, 2012; PURCELL; BOUTTE; CROSSON, 2008; TSOKOS; LAUB, 2012). A complexidade da regulação dos eventos de progressão do ciclo fica mais evidente quando se constata que: i) estas proteínas têm localização espacial definida, que se altera durante as fases do ciclo; ii) a ativação (ou inativação) destas ocorre de forma ordenada espacial e temporalmente; iii) existe o controle do posicionamento do cromossomo, com a origem de replicação voltada para o pólo flagelado e o término de replicação voltado para o pólo oposto, havendo correlação linear entre a posição dos loci no interior da célula e sua distância da origem (GOLEY; INIESTA; SHAPIRO, 2007; VIOLLIER et al., 2004). Acredita-se que este posicionamento característico do cromossomo contribua para o controle espacial e temporal da expressão gênica durante o ciclo celular de $C$. crescentus (VIOLLIER; SHAPIRO, 2004).

A complexidade do ciclo de vida de $C$. crescentus, aliada à sua adaptação ao meio ambiente, torna esta bactéria um modelo excelente para o estudo de genes de resposta a estresses ambientais e de como sua regulação é realizada em conjunto com o programa de desenvolvimento. Alguns estudos já mostraram que existe integração entre sinais ambientais e alterações em aspectos do desenvolvimento celular desta espécie bacteriana. Sabe-se que o comprimento do talo é diretamente proporcional ao número de divisões e, consequentemente, à idade da célula; ao mesmo tempo, o comprimento do talo é inversamente proporcional à concentração de fosfato no meio (SCHMIDT; STANIER, 1966). PhoB, um regulador de resposta de um sistema de dois componentes, controla o comprimento do talo em resposta a sinais enviados pelo sistema de tomada de fosfato Pts (GONIN et al., 2000), mostrando que um sinal ambiental pode alterar certos aspectos do desenvolvimento celular.

Pelo exemplo acima, nota-se que o controle do desenvolvimento celular não é um processo fixo, mas maleável, com certos fatores dependentes das condições ambientais em que a célula se encontra. Sendo assim, uma regulação fina do ciclo é necessária para que todos os estímulos sejam integrados e o ciclo ocorra da maneira mais adequada e no momento propício. Apesar dos extensos estudos, ainda não se sabe quais estímulos desencadeiam a diferenciação da célula móvel para célula-talo; no entanto, cada vez mais há indícios de que sinais ambientais são importantes para este processo.

C. crescentus foi a primeira $\alpha$-proteobactéria de vida livre a ter o genoma sequenciado (NIERMAN et al., 2001), sendo constantemente reanalisado (ELY; SCOTT, 2014; SCHRADER et al., 2014), o que permite o seu estudo através de uma variedade de técnicas genéticas, bioquímicas e de biologia celular. Alguns componentes genéticos de C. crescentus, 
como o regulador CtrA e parte de seu regulon, já foram observados em outras bactérias do mesmo grupo, indicando uma conservação evolutiva (CURTIS; BRUN, 2014; HALLEZ et al., 2004; SKERKER; LAUB, 2004). Embora nestas espécies não se observe divisão assimétrica conspícua como ocorre em C. crescentus, sugeriu-se que os homólogos destes genes estariam atuando em um mecanismo de controle da polaridade celular, utilizado para adaptação a diferentes nichos ecológicos durante a evolução das $\alpha$-proteobactérias (HALLEZ et al., 2004). Sendo assim, o estudo de C. crescentus também pode fornecer informações sobre mecanismos comuns a este grupo de bactérias, ao qual pertencem os simbiontes de plantas Sinorhizobium meliloti e Mesorhizobium loti, o patógeno de plantas Agrobacterium tumefaciens e os patógenos de mamíferos Rickettsia prowazekii e Brucella abortus. A importância ambiental e médica de representantes deste grupo torna o estudo de C. crescentus interessante como base para a biologia das $\alpha$-proteobactérias e para a identificação de novos alvos para drogas antibacterianas contra espécies patogênicas (SKERKER; LAUB, 2004).

\subsection{Captação do ferro e sua importância em bactérias}

O ferro é um micronutriente essencial para a maioria dos organismos, participando em muitos processos importantes, como respiração, ciclo do ácido cítrico, transporte de oxigênio, regulação gênica, biossíntese de DNA, fotossíntese, fixação de nitrogênio, metanogênese e produção de $\mathrm{H}_{2}$ (ANDREWS; ROBINSON; RODRIGUEZ-QUINONES, 2003). Sua funcionalidade biológica é quase inteiramente dependente de sua incorporação em proteínas, tanto na forma de átomos isolados quanto em formas mais complexas, como grupos heme ou complexos de ferro-enxofre. No entanto, em condições aeróbias, a forma predominante de ferro é a forma oxidada $\mathrm{Fe}^{3+}$, que é extremamente insolúvel em ambientes aquosos (SAHA et al., 2013). Mesmo se a célula dispuser da forma reduzida $\mathrm{Fe}^{2+}$, o excesso desta pode ser extremamente tóxico em condições aeróbias. A forma reduzida $\mathrm{Fe}^{2+}$ reage com o peróxido de hidrogênio intracelular, originando o radical hidroxil $\left(\mathrm{OH}^{-}\right)$, com potencialidade de oxidar instantaneamente qualquer composto orgânico de uma célula, podendo danificar macromoléculas e componentes celulares (TOUATI, 2000). Ainda, no caso de organismos parasitas, adquirir ferro torna-se mais difícil pelo fato de o hospedeiro utilizar proteínas ligantes de ferro com alta afinidade pelo metal, como transferrina e lactoferrina (SCHAIBLE; KAUFMANN, 2004). Portanto, na presença de oxigênio, o ferro se encontra pouco disponível e é potencialmente tóxico. Assim, para alcançar uma homeostase de ferro eficiente, os 
organismos precisam controlar a captação de ferro de modo a suprir as necessidades deste metal, evitando, em contrapartida, a toxicidade induzida por ele.

Existem várias estratégias utilizadas pelas bactérias para o gerenciamento da captação e utilização do ferro. Dentre elas, podem ser citados: transporte de $\mathrm{Fe}^{2+}$ em condições anaeróbias; sistemas de transporte com alta afinidade por diferentes formas de ferro (Fig. 2); armazenamento de ferro em depósitos intracelulares, para utilização deste em condições de escassez de ferro no meio ambiente; sistemas de resistência a estresse oxidativo induzido por ferro; controle da expressão de proteínas contendo ferro de acordo com sua disponibilidade no ambiente; aquisição de ferro por espécies patógenas através de heme ou proteínas do hospedeiro (hemopexina, hemoglobina, transferrina, lactoferrina etc.); secreção de quelantes de ferro, denominados sideróforos, para solubilizar e internalizar compostos férricos existentes no meio ambiente; entre outras (BRAUN; KILLMANN, 1999).

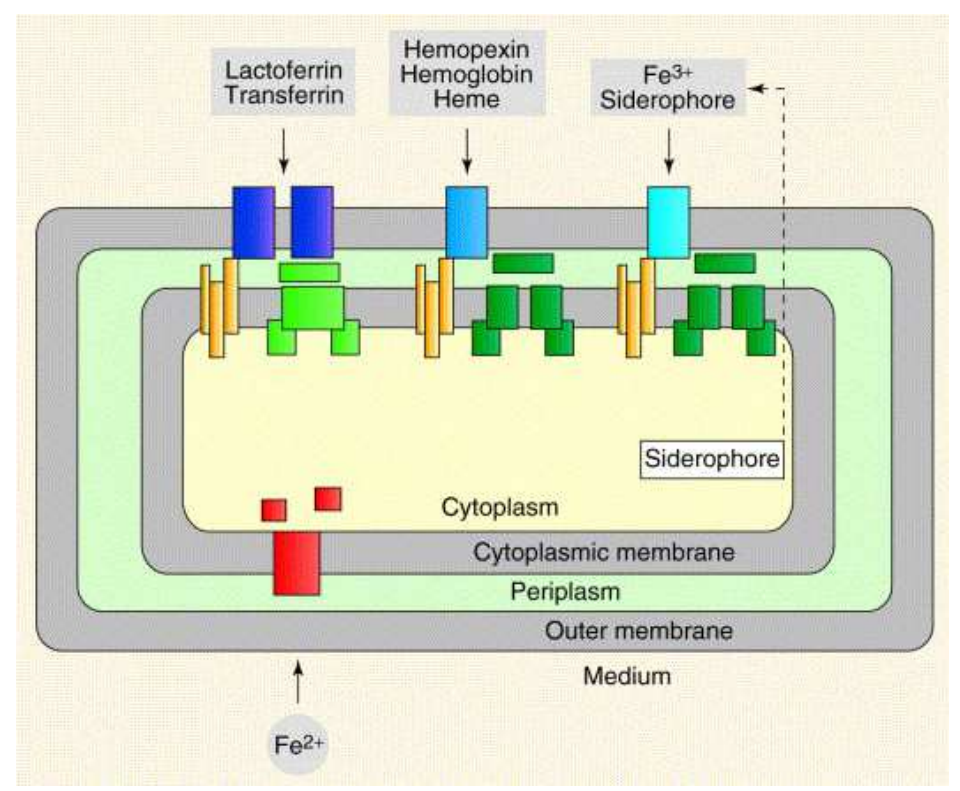

Figura 2 - Sistemas de captação de ferro em bactérias Gram-negativas. Em bactérias patógenas, o ferro pode ser captado na forma de $\mathrm{Fe}^{3+}$ através de proteínas ligantes de ferro do hospedeiro, como transferrina e lactoferrina, ou na forma de heme, diretamente ou após sua retirada da hemoglobina e hemopexina. $\mathrm{Fe}^{3+}$ também pode ser obtido através de sideróforos, que são quelantes orgânicos de ferro produzidos por bactérias e fungos. O transporte ativo de ferro através da membrana utiliza a energia oriunda do gradiente de prótons da membrana citoplasmática, sendo transmitida à membrana externa através do sistema TonB-ExbB-ExbD (em amarelo; ver texto). Proteínas de transporte ancoradas na membrana externa encontram-se representadas em azul; as periplasmáticas e as de membrana citoplasmática estão representadas em verde. $\mathrm{O}$ transporte através da membrana citoplasmática ocorre à custa de ATP. $\mathrm{O}$ íon $\mathrm{Fe}^{2+}$ presumivelmente passa pela membrana externa por difusão, e seu transporte até o citoplasma é feito ativamente por proteínas como feoAB (em vermelho).

FONTE: Retirado de Braun e Killmann (1999). 
A captação de ferro mediada por sideróforos é a forma mais comum de aquisição do metal entre as bactérias. Os sideróforos são moléculas orgânicas de baixo peso molecular (< $1000 \mathrm{Da})$, com alta afinidade e especificidade por $\mathrm{Fe}^{3+}$, sendo categorizados em hidroxamatos, $\alpha$-hidroxicarboxilatos e catecóis conforme sua estrutura (WINKELMANN, 2002). São produzidos e secretados por bactérias, fungos e plantas monocotiledôneas em resposta à carência de ferro (ANDREWS; ROBINSON; RODRIGUEZ-QUINONES, 2003), e são importantes para a sobrevivência de bactérias do solo e de ambientes aquáticos (GUERINOT, 1994) e essenciais para a virulência de muitos patógenos de animais (RATLEDGE; DOVER, 2000).

O transporte passivo de sideróforos ligados a ferro não é possível devido ao tamanho destas moléculas, grandes demais para passarem por porinas, e às suas baixas concentrações sob a maioria das condições ambientais, impedindo o transporte por difusão (BRAUN; KILLMANN, 1999). Em bactérias Gram-negativas, a captação de sideróforos contendo ferro ocorre através de receptores de membrana externa, em um processo dependente de energia (KOSTER, 2001). A energia é transmitida aos receptores através do sistema TonB-ExbBExbD, localizado na membrana citoplasmática, sendo que TonB interage fisicamente com o receptor de membrana externa (Fig. 3). Acredita-se que ExbB e ExbD utilizam o potencial eletroquímico da membrana para produzir uma forma "energizada" de TonB, que proporciona uma mudança conformacional no receptor de membrana externa quando o sideróforo se liga a este. Isto leva à translocação do sideróforo contendo ferro para o periplasma. Proteínas de ligação periplasmáticas levam os sideróforos contendo ferro até transportadores do tipo $\mathrm{ABC}$

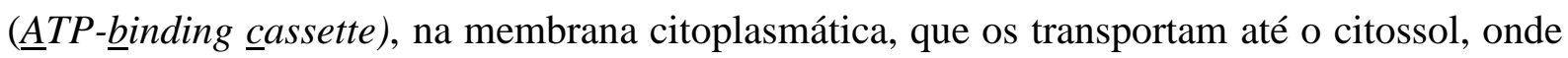
ocorre a redução do ferro, diminuindo a afinidade do sideróforo pelo íon e dissociando o complexo (ANDREWS; ROBINSON; RODRIGUEZ-QUINONES, 2003). Bactérias Grampositivas também utilizam transportadores do tipo ABC para o transporte de sideróforos, porém não utilizam o sistema TonB-ExbB-ExbD e os receptores são análogos às proteínas de ligação periplasmáticas de Gram-negativas, encontrando-se ancorados diretamente na membrana citoplasmática (KOSTER, 2001). Os sideróforos podem ser captados por diferentes espécies de bactérias, mesmo por aquelas que não os secretam (SCHALK; GUILLON, 2013). 


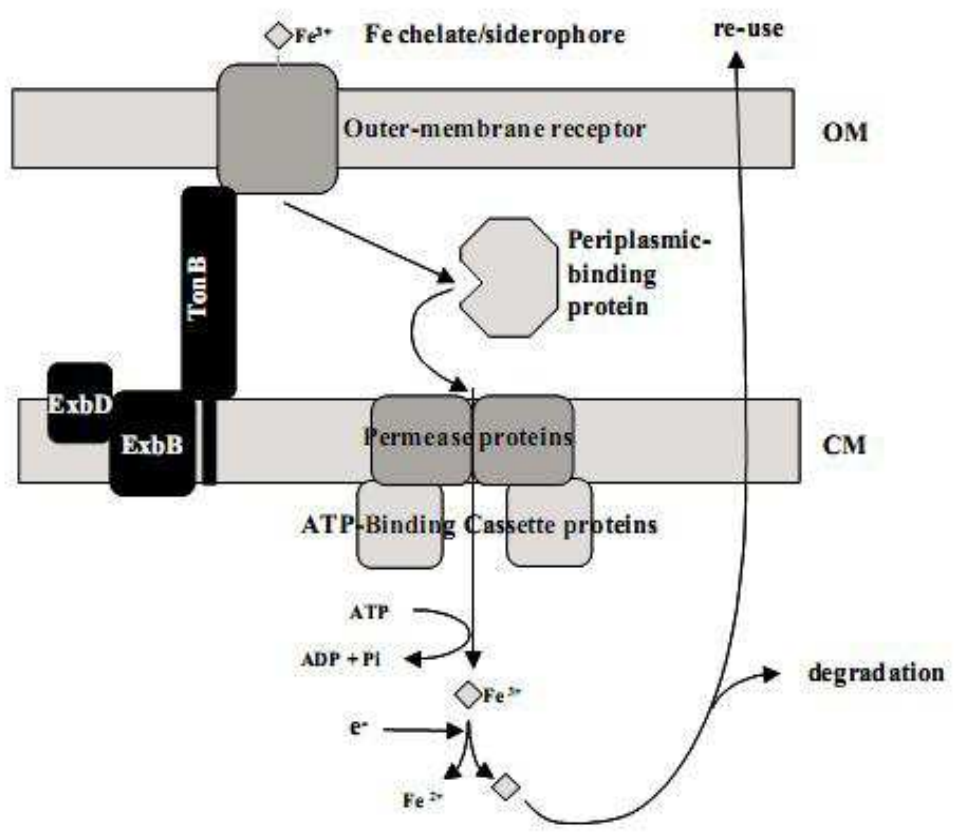

Figura 3 - Representação esquemática do sistema de captação de ferro mediada por sideróforos em bactérias Gram-negativas. O complexo TonB-ExbB-ExbD (em preto) fornece a energia necessária para o transporte do sideróforo contendo ferro através do receptor de membrana externa. A proteína de ligação periplasmática leva o sideróforo até o complexo transportador do tipo $\mathrm{ABC}$, na membrana citoplasmática. O sideróforo é internalizado através da hidrólise do ATP e o ferro é separado do sideróforo através de uma reação de redução. O sideróforo é degradado ou reutilizado. $\mathrm{OM}$, membrana externa; $\mathrm{CM}$, membrana citoplasmática.

FONTE: Retirado de Andrews, Robinson e Rodriguez-Quinones (2003).

\subsection{Regulação gênica dependente de ferro}

Tipicamente, as bactérias regulam o metabolismo de ferro em resposta à disponibilidade do metal no ambiente. Em Escherichia coli e muitas outras bactérias, esta regulação é mediada por Fur (ferric-uptake regulator protein), que controla a expressão de mais de 90 genes dependentes de ferro naquela bactéria (HANTKE, 2001; HANTKE; BRAUN, 2000). A ação de Fur é primariamente de repressor da transcrição de genes relacionados à captação de ferro, sendo necessário $\mathrm{Fe}^{2+}$ como co-repressor e sinalizador da disponibilidade de ferro (ANDREWS; ROBINSON; RODRIGUEZ-QUINONES, 2003). O complexo $\mathrm{Fe}^{2+}$-Fur geralmente se liga entre os sítios -35 e -10 dos promotores dos genes reprimidos por Fur, em uma seqüência palindrômica conhecida como "Fur box". Na ausência de $\mathrm{Fe}^{2+}$, Fur não se liga ao DNA e não mais reprime a transcrição destes genes, de modo que a expressão destes depende da presença de $\mathrm{Fe}^{2+}$ disponível para associação com Fur, estabelecendo um controle entre a disponibilidade do metal e a expressão dos genes 
necessários para sua captação (ANDREWS; ROBINSON; RODRIGUEZ-QUINONES, 2003). Em bactérias Gram-positivas, a proteína DtxR assume uma função semelhante à de Fur (HANTKE, 2001).

No entanto, há genes não relacionados ao metabolismo de ferro cuja expressão também é reprimida por $\mathrm{Fe}^{2+}$-Fur, sendo alguns destes genes relacionados a processos como respiração, ciclo do ácido cítrico, glicólise, síntese de DNA, metabolismo de purinas e quimiotaxia (PARK; GUNSALUS, 1995; STOJILJKOVIC; BAUMLER; HANTKE, 1994; TOUATI, 1988; VASSINOVA; KOZYREV, 2000). Portanto, Fur pode ser considerado um regulador global da expressão gênica, como observado para E. coli, P. aeruginosa e B. subtilis (ANDREWS; ROBINSON; RODRIGUEZ-QUINONES, 2003).

Há algumas evidências de que Fur não atua somente como repressor, mas também como ativador transcricional de certos genes (DA SILVA NETO et al., 2009; MASSE; GOTTESMAN, 2002; PARK; GUNSALUS, 1995; TSENG, 1997). No entanto, na maioria dos casos esta ativação é indireta, sendo ocasionada pela ação repressora de Fur sobre o gene ryhB, que codifica um pequeno RNA regulatório, que por sua vez tem ação repressora sobre a expressão de determinados genes (MASSE; GOTTESMAN, 2002). Estes genes, em grande parte dos casos, codificam proteínas contendo ferro em sua estrutura ou proteínas de armazenamento de ferro. Assim, a ação conjunta de Fur e RyhB promove um mecanismo de inibição da síntese de sistemas de transporte de ferro na presença de concentrações altas deste metal, mas com a concomitante ativação da síntese de sistemas de armazenamento de ferro e de proteínas contendo ferro em sua estrutura, para aproveitamento das concentrações favoráveis do metal (PORCHERON et al., 2013).

Outro grau de regulação da expressão gênica mediada por ferro é exercido por fatores sigma. Fatores sigma são subunidades da holoenzima RNA polimerase necessárias para a iniciação da transcrição dos genes em um dado promotor, e a maioria das bactérias possui múltiplos fatores sigma, que permitem o reconhecimento de diferentes conjuntos de promotores (DECKER; HINTON, 2013). Geralmente, existe um fator sigma principal responsável pelo reconhecimento da maioria dos promotores, e vários fatores sigma alternativos, que se acumulam em resposta a estresses específicos, direcionando a RNA polimerase para outros conjuntos de promotores, de modo que os genes agora expressos auxiliem a célula a enfrentar o estresse em questão (DECKER; HINTON, 2013; MAGNUSSON; FAREWELL; NYSTROM, 2005). Dentre os fatores sigma alternativos, existem aqueles designados como tendo função extracitoplasmática (ECF), encontrados em diversas espécies bacterianas, sendo responsáveis principalmente pela expressão de genes em 
resposta a danos ao envelope celular causados por sinais ambientais, como choque de calor, estresse osmótico e estresse oxidativo (LONETTO et al., 1994; MISSIAKAS; RAINA, 1998). Múltiplos membros da família ECF podem estar presentes na mesma espécie. A regulação destes fatores sigma, muitas vezes, é efetuada de modo pós-traducional por outras proteínas, seus respectivos fatores antissigma, que modulam a atividade dos fatores sigma de modo póstraducional (BROWNING; BUSBY, 2004). Muitos fatores antissigma se encontram ancorados na membrana citoplasmática e sequestram o respectivo fator sigma, de modo que este não se encontra livre para se combinar com a RNA polimerase. A atividade dos fatores antissigma é regulada por pequenos ligantes, modificação covalente ou proteólise, fatores geralmente desencadeados por sinais ambientais (BROWNING; BUSBY, 2004). Há casos particulares em que a via de sinalização que culmina na ativação do fator sigma ECF inclui fatores com função anti-antissigma; estes fatores mimetizam em parte um fator sigma e competem pela ligação ao antissigma, permitindo a ativação do fator sigma verdadeiro (FRANCEZ-CHARLOT et al., 2009; LOURENÇO; KOHLER; GOMES, 2011).

Em Escherichia coli, FecI é um fator sigma ECF citossólico, que age como ativador do operon $f e c A B C D E$, que codifica um sistema de transporte de citrato férrico (ANGERER et al., 1995; BRAUN, 1997). Este operon e o operon $f e c I R$ são sujeitos à repressão por $\mathrm{Fe}^{2+}$-Fur. $\mathrm{Na}$ ausência de citrato férrico, FecR, uma proteína de membrana citoplasmática com função de antissigma de FecI, mantém FecI ligado a si, impedindo-o de agir como ativador transcricional. Quando citrato férrico se liga ao receptor de membrana externa FecA, isto causa a ativação de FecR (Fig. 4). O citrato férrico é translocado para o periplasma em um processo que requer energia e depende de FecA, TonB, ExbB e ExbD. FecB é uma proteína periplasmática que se liga ao citrato férrico, enquanto FecCDE são integrantes do sistema de transporte do tipo $\mathrm{ABC}$, que irão promover a entrada do citrato férrico no citossol. Com a ativação de FecR por FecA, através da interação direta entre a extensão N-terminal de FecA e a C-terminal de FecR no periplasma, o fator sigma FecI é liberado para interagir com a RNA polimerase, a fim de transcrever o operon fecABCDE (BRAUN; MAHREN; OGIERMAN, 2003). Surpreendentemente, o fator sigma FecI parece ser absolutamente específico para o operon $f e c A B C D E$ (ANDREWS; ROBINSON; RODRIGUEZ-QUINONES, 2003).

FecA é um receptor dependente de TonB, pois depende do sistema TonB-ExbB-ExbD para realizar sua função de transporte do citrato férrico. Porém, FecA também transmite o sinal para liberação do fator sigma FecI diretamente para o antissigma FecR, e por isso faz parte de um grupo de receptores dependentes de TonB também denominados transdutores dependentes de TonB (KOEBNIK, 2005). Esta característica é devida à presença da extensão 
$\mathrm{N}$-terminal destes transdutores, de aproximadamente 40 resíduos de aminoácidos, que permite a interação entre FecA na membrana externa e FecR na membrana citoplasmática. A deleção desta porção em FecA bloqueia a transmissão do sinal, mas não o transporte de citrato férrico, indicando que o transporte não é necessário para a indução do sistema, ao contrário da ligação da molécula ao receptor (BRAUN; KILLMANN, 1999).

Fatores sigma ECF relacionados a FecI foram encontrados em outras bactérias, como PvdS em $P$. aeruginosa, que controla a biossíntese de um sideróforo e também é regulado negativamente por $\mathrm{Fe}^{2+}$-Fur (VISCA et al., 2002). FecI e PvdS fazem parte de uma subfamília de fatores sigma ECF envolvidos no metabolismo de ferro e presentes em uma grande variedade de espécies microbianas, conhecidos como fatores sigma de carência de ferro. FecI é o único representante desta subfamília em $E$. coli, enquanto $P$. aeruginosa possui 14 fatores sigma relacionados (VISCA et al., 2002). Em árvores filogenéticas, esta subfamília de fatores sigma ECF de bactérias taxonomicamente diversas forma um clado bem definido, separado dos outros tipos de fatores sigma ECF (VISCA et al., 2002).

Assim como fecI de E. coli, todos os genes codificando fatores sigma de carência de ferro em $P$. aeruginosa (com exceção de PA2426, codificando PvdS) estão adjacentes a genes semelhantes a $f e c R$ (Fig. 5A). Isto indica que estes genes podem codificar representantes (fatores sigma e antissigma) do modelo geral de regulação de fatores sigma ECF, respondendo a estímulos vindos da superfície celular. Dentre estes 13 pares de genes de $P$. aeruginosa, dez deles estão também adjacentes a genes codificando possíveis receptores de membrana externa envolvidos no transporte de ferro e com sequências similares a fecA (Fig. 5), podendo caracterizar sistemas transdutores dependentes de TonB. 


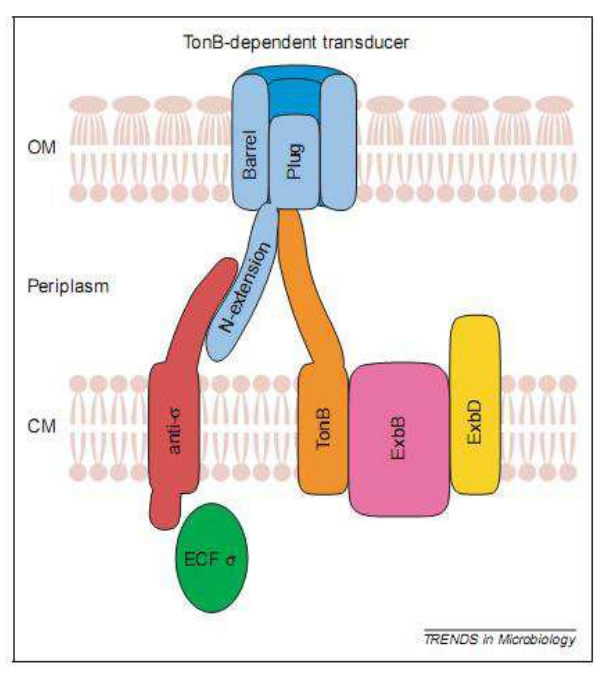

Figura 4 - Organização estrutural de sistemas regulatórios dependentes de TonB. Estes sistemas consistem em seis componentes: um receptor/transdutor dependente de TonB na membrana externa, com uma extensão N-terminal (azul); o complexo energético TonB-ExbB-ExbD (laranja, rosa e amarelo); o antissigma na membrana citoplasmática (vermelho) e o fator sigma do tipo ECF (verde). $\mathrm{OM}$, membrana externa; CM, membrana citoplasmática. FecA, FecR e FecI de E. coli correspondem, respectivamente, às estruturas representadas em azul, vermelho e verde. Os componentes do sistema de transporte FecBCDE não aparecem representados para maior clareza.

FONTE: Retirado de Koebnik (2005).

A

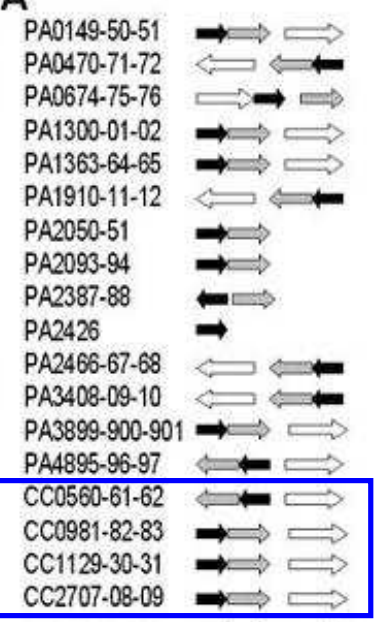

B

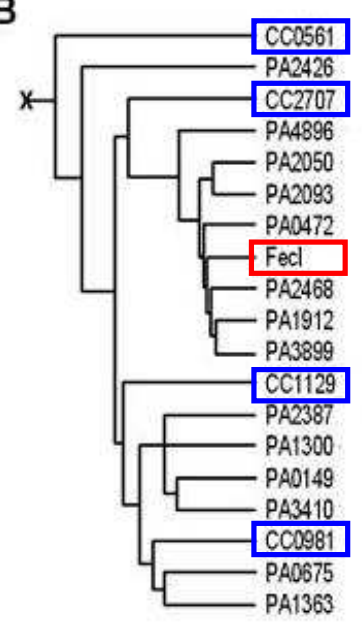

Figura 5 - Organização gênica e aspectos evolutivos dos sistemas de sinalização de superfície regulados por ferro em Pseudomonas aeruginosa e Caulobacter crescentus. (A) Organização dos genes ortólogos a fecI (preto), $f e c R$ (cinza) e $f e c A$ (branco) nos genomas de $P$. aeruginosa (PA) e $C$. crescentus (CC, demarcados pela caixa azul). Os genes estão orientados de acordo com a direção da transcrição. (B) Árvore filogenética relacionando fatores sigma ECF da subfamília FecI de $P$. aeruginosa, C. crescentus (demarcados pelas caixas azuis) e E. coli (FecI, demarcado pela caixa vermelha).

FONTE: Modificado de Visca et al. (2002). 


\subsection{Homeostase de ferro em Caulobacter crescentus e genes relacionados}

Em C. crescentus, Fur é o principal regulador da resposta à carência de ferro, e possui um importante papel na resistência a estresse oxidativo causado por peróxido de hidrogênio (DA SILVA NETO et al., 2009; DA SILVA NETO; LOURENÇO; MARQUES, 2013). Vários sítios de ligação a Fur foram identificados no genoma de C. crescentus por análises in silico, sendo 11 deles confirmados experimentalmente, incluindo regiões a montante de quatro genes codificando receptores dependentes de TonB (DA SILVA NETO et al., 2009). Muitos dos genes e operons regulados por Fur em C. crescentus codificam sistemas envolvidos na captação de ferro (como os receptores dependentes de TonB) e enzimas contendo ferro importantes para o metabolismo energético, como NADH desidrogenase, succinato desidrogenase, aconitato hidratase, citocromo $c$ oxidase e ATP sintase (DA SILVA NETO et al., 2009). Porém, como outros genes não relacionados à homeostase de ferro também são regulados por Fur em $C$. crescentus, esta proteína pode ser considerada um regulador global.

A análise global da transcrição de $C$. crescentus em resposta à disponibilidade de ferro mostrou que 42 genes são fortemente induzidos tanto pela mutação em fur quanto por limitação de ferro (DA SILVA NETO; LOURENÇO; MARQUES, 2013). A sobreposição de genes induzidos pela mutação em fur com genes induzidos por carência de ferro confirma o papel de Fur na repressão destes genes quando ferro se encontra disponível. Esta análise global também confirmou o papel de Fur como ativador transcricional de genes envolvidos no metabolismo energético, em particular codificando enzimas que utilizam ferro em sua estrutura. Porém, a limitação de ferro não afeta apenas o modulon de Fur; outros 113 genes têm sua expressão alterada nesta condição, incluindo genes envolvidos na montagem de grupos Fe-S e resposta a estresse oxidativo (induzidos), além de genes envolvidos no metabolismo de aminoácidos, quimiotaxia e motilidade (reprimidos) (DA SILVA NETO; LOURENÇO; MARQUES, 2013).

O sequenciamento do genoma de $C$. crescentus revelou a presença de 67 genes codificando receptores dependentes de TonB, presumivelmente importantes para o crescimento de $C$. crescentus em ambientes aquáticos diluídos (KOEBNIK, 2005; NIERMAN et al., 2001). Este número é muito alto, se comparado ao número de genes para estes receptores em P. aeruginosa (35) e E. coli (13) (VISCA et al., 2002). Destes 67 genes, quatro foram identificados como sendo regulados por Fur, tanto por análises de bioinformática quanto empiricamente (DA SILVA NETO et al., 2009), sendo também induzidos por carência de ferro (DA SILVA NETO; LOURENÇO; MARQUES, 2013); isto indica que estes genes 
são sujeitos à repressão por Fur juntamente com $\mathrm{Fe}^{2+}$ como cofator. Outros quatro genes codificando receptores dependentes de TonB apresentam sítios de ligação a Fur em suas sequências regulatórias, porém mais flexíveis (DA SILVA NETO et al., 2009).

C. crescentus possui 13 genes codificando fatores sigma $\mathrm{ECF}$, quatro dos quais $\left(\sigma^{\mathrm{E}}\right.$, $\sigma^{\mathrm{F}}, \sigma^{\mathrm{T}}$ e $\sigma^{\mathrm{U}}$ ) estão envolvidos com a resposta celular a metais pesados, entre outras funções (KOHLER et al., 2012). Análises genômicas revelaram que outros quatro fatores sigma ECF são presumivelmente da subfamília FecI, com organizações gênicas dos ortólogos de $f e c A$, $f e c I$ e $f e c R$ seguindo modelos também encontrados em P. aeruginosa (Fig. 5) (NIERMAN et al., 2001; VISCA et al., 2002). Várias cópias de genes codificando fatores sigma ECF da subfamília FecI são comumente encontradas em espécies bacterianas de ambientes aquáticos ou solo, indicando que estes ambientes podem ser complexos com relação à variedade de compostos férricos disponíveis (VISCA et al., 2002).

$\mathrm{O}$ envolvimento de fatores sigma do tipo ECF na síntese e transporte de compostos férricos foi estudado em detalhe apenas em E. coli, com o sistema de citrato férrico, e em algumas espécies do gênero Pseudomonas, como P. aeruginosa, $P$. fluorescens e $P$. putida, com sistemas de biossíntese de sideróforos. No entanto, a análise dos genomas sequenciados disponíveis evidencia que tais sistemas estão distribuídos em inúmeras espécies bacterianas, e mesmo dentro de uma mesma espécie, como no caso de $P$. aeruginosa e $C$. crescentus (VISCA et al., 2002).

Ao contrário de E. coli e $P$. aeruginosa, não foram encontrados sítios de ligação a Fur nos quatro sistemas preditos como fatores sigma de carência de ferro em C. crescentus (DA SILVA NETO et al., 2009), sugerindo que eles podem não ser regulados em resposta à disponibilidade de ferro. Apesar de o uso de sideróforos por C. crescentus ter sido descrito anteriormente (NEUGEBAUER et al., 2005), não há sistemas óbvios de síntese de sideróforos codificados em seu genoma, indicando que esta espécie utiliza sideróforos produzidos por outras fontes. Além disso, não há ortólogos de fecBCDE de E. coli no genoma de $C$. crescentus (RODIONOV et al., 2006), que em E. coli constitui provavelmente o único operon reconhecido por FecI.

Na maioria das espécies bacterianas estudadas, a presença de sítios de ligação de Fur à frente dos genes codificando fatores sigma do tipo FecI ressalta o envolvimento destes genes na captação de ferro, sendo este envolvimento confirmado experimentalmente em muitos casos. No entanto, este não é o caso em $C$. crescentus, o que constitui uma importante diferença em relação ao sistema padrão de E. coli. O papel destes sistemas regulatórios e sua possível relação com a expressão de genes envolvidos na síntese e captação de sideróforos ou 
compostos férricos ainda não haviam sido estudados em C. crescentus. Como exposto, esta bactéria apresenta várias particularidades em aspectos considerados cruciais para o funcionamento de sistemas do tipo FecI-FecR-FecA na homeostase de ferro em outras espécies. Estas particularidades e os questionamentos que elas causam levaram à proposição e ao desenvolvimento deste trabalho. 


\section{OBJETIVOS}

Este trabalho teve por objetivo caracterizar dois sistemas regulatórios contendo fatores sigma da família FecI de $C$. crescentus quanto ao seu possível papel na manutenção da homeostase de ferro. Procurou-se investigar o papel de cada fator sigma através da análise de sua expressão, dos fenótipos de mutantes nulos e da identificação de seus alvos regulatórios. Para isso, as estratégias utilizadas foram as seguintes:

a) avaliação da expressão dos genes pertencentes aos sistemas $f e c I-f e c R-f e c A$ em diferentes condições relacionadas à homeostase de ferro;

b) obtenção de mutantes nulos para genes codificando componentes de dois dos sistemas fecI-fecR-fecA de C. crescentus;

c) análise de possíveis mudanças fenotípicas decorrentes da deleção destes genes em relação à sobrevivência, captação e transporte de compostos férricos;

d) determinação de possíveis alvos regulatórios dos fatores sigma selecionados através de microarranjos de cDNA. 


\section{MATERIAL E MÉTODOS}

\subsection{Linhagens bacterianas e condições de crescimento}

As linhagens utilizadas neste trabalho estão descritas na tabela 1. Caulobacter crescentus NA1000 (EVINGER; AGABIAN, 1977) foi cultivada a $30{ }^{\circ} \mathrm{C}$ em meio PYE ou meio mínimo M2 (ELY, 1991) contendo diferentes fontes de ferro (sulfato ferroso, citrato férrico ou cloreto de hemina) a uma concentração de $100 \mu \mathrm{M}$. Quando necessário, os meios foram suplementados com os antibióticos ácido nalidíxico $(20 \mu \mathrm{g} / \mathrm{ml})$, tetraciclina $(1 \mu \mathrm{g} / \mathrm{ml})$ ou canamicina $(5 \mu \mathrm{g} / \mathrm{ml})$, ou ágar para preparo de meios sólidos $(1,5 \%)$.

Para procedimentos de clonagem, foram utilizadas células de Escherichia coli DH5 $\alpha$ (HANAHAN, 1983), e para introdução de plasmídeos em C. crescentus por conjugação bacteriana, utilizou-se a linhagem de E. coli S17-1 (SIMON; PRIEFER; PÜHLER, 1983). E. coli foi cultivada a $37^{\circ} \mathrm{C}$ em meio Luria-Bertani suplementado com ampicilina $(100 \mu \mathrm{g} / \mathrm{ml})$, tetraciclina $(12,5 \mu \mathrm{g} / \mathrm{ml})$ ou canamicina $(50 \mu \mathrm{g} / \mathrm{ml})$ quando necessário.

Tabela 1. Linhagens bacterianas utilizadas neste trabalho.

\begin{tabular}{|c|c|c|c|}
\hline & Linhagens & Genótipo e/ou fenótipo & Referência \\
\hline \multirow[b]{2}{*}{ Escherichia coli } & S17-1 & 294::RP4-2(Tc::Mu)(Km::Tn7) & $\begin{array}{c}\text { Simon, Priefer e } \\
\text { Pühler (1983) }\end{array}$ \\
\hline & DH5 $\alpha$ & $\begin{array}{c}\text { supE44 DlacU169 } \\
(\Phi 80 l a c Z \Delta \mathrm{M} 15) \text { hsdR17 recAl } \\
\text { endA1 gyrA96 thi-1 relAl }\end{array}$ & Hanahan (1983) \\
\hline \multirow{6}{*}{$\begin{array}{l}\text { Caulobacter } \\
\text { crescentus }\end{array}$} & NA1000 & $\begin{array}{l}\text { Linhagem sincronizável } \\
\text { utilizada como padrão }\end{array}$ & $\begin{array}{c}\text { Evinger e Agabian } \\
(1977)\end{array}$ \\
\hline & $\Delta f u r$ & NA1000 $\Delta f u r$ & $\begin{array}{c}\text { da Silva Neto et al. } \\
\text { (2009) }\end{array}$ \\
\hline & $\Delta f e c A 2$ & NA1000 $\Delta$ CCNA_01189 & Este trabalho \\
\hline & $\Delta f e c R 2$ & NA1000 $\Delta$ CCNA_01188 & Este trabalho \\
\hline & $\Delta f e c I 4$ & NA1000 $\triangle$ CCNA_00596 & Este trabalho \\
\hline & $\Delta f e c R 4$ & NA1000 $\Delta$ CCNA_00595 & Este trabalho \\
\hline
\end{tabular}




\subsection{Plasmídeos e oligonucleotídeos utilizados}

As tabelas 2 e 3 listam os plasmídeos e oligonucleotídeos utilizados neste trabalho.

\section{Tabela 2. Plasmídeos utilizados.}

\begin{tabular}{|c|c|c|}
\hline Plasmídeo & Características $^{a}$ & Fonte ou referência \\
\hline pGEM & Vetor de clonagem, $\mathrm{Ap}^{\mathrm{r}}$ & Promega $^{b}$ \\
\hline pRKlacZ290 & $\begin{array}{l}\text { Vetor de fusão de transcrição } l a c Z, \mathrm{Tc}^{\mathrm{r}} \text {, } \\
\text { replicon IncP1, oriT }\end{array}$ & Gober e Shapiro (1992) \\
\hline pNPTS138 & Replicon ColE1, oriT, npt $\left(\mathrm{Km}^{\mathrm{r}}\right), \operatorname{sacB}$ & D. Alley \\
\hline $\mathrm{Pfec} 1 / / a c Z$ & $\begin{array}{c}\text { pRKlacZ290 com a região promotora da } \\
\text { ORF CCNA_02790 }\end{array}$ & Este trabalho \\
\hline $\mathrm{P} f e c 2 / l a c Z$ & $\begin{array}{c}\text { pRKlacZ290 com a região promotora da } \\
\text { ORF CCNA_01187 }\end{array}$ & Este trabalho \\
\hline $\mathrm{P} f e c 3 / l a c Z$ & $\begin{array}{c}\text { pRKlacZ290 com a região promotora da } \\
\text { ORF CCNA_01032 }\end{array}$ & Este trabalho \\
\hline $\mathrm{P} f e c 4 / l a c Z$ & $\begin{array}{c}\text { pRKlacZ290 com a região promotora da } \\
\text { ORF CCNA_00596 }\end{array}$ & Este trabalho \\
\hline pCCNA_02277/lacZ & $\begin{array}{c}\text { pRKlacZ290 com a região promotora da } \\
\text { ORF CCNA_02277 }\end{array}$ & $\begin{array}{l}\text { da Silva Neto et al. } \\
\qquad(2009)\end{array}$ \\
\hline PtonB $2 / l a c Z$ & $\begin{array}{c}\text { pRKlacZ290 com a região promotora da } \\
\text { ORF CCNA_01189 }\end{array}$ & Este trabalho \\
\hline PtonB3/lacZ & $\begin{array}{c}\text { pRKlacZ290 com a região promotora da } \\
\text { ORF CCNA_01034 }\end{array}$ & Este trabalho \\
\hline PtonB4/lacZ & $\begin{array}{c}\text { pRKlacZ290 com a região promotora da } \\
\text { ORF CCNA_00597 }\end{array}$ & Este trabalho \\
\hline
\end{tabular}

${ }^{a} \mathrm{Ap}^{\mathrm{r}}$, marca de resistência a ampicilina; $\mathrm{Km}^{\mathrm{r}}$, marca de resistência a canamicina; $\mathrm{Tc}^{\mathrm{r}}$, a tetraciclina.

${ }^{b}$ Promega Co., Madison, WI, E.U.A. 
Tabela 3. Oligonucleotídeos utilizados.

\begin{tabular}{|c|c|c|}
\hline Nome & Seqüêencia $\left(5^{\prime}-3^{\prime}\right)^{a}$ & Propósito \\
\hline FEC1-A & TAGGATCCATGCCAGAAAGATAAGTGGC ${ }^{(1)}$ & $\begin{array}{l}\text { Amplificação do } \\
\text { promotor } \mathrm{P} f e c l\end{array}$ \\
\hline FEC1-B & GATAAGCTTATCTCGCGAGACGATTTGCG ${ }^{(2)}$ & $\begin{array}{l}\text { Amplificação do } \\
\text { promotor Pfecl }\end{array}$ \\
\hline FEC2-A & TTGGATCCTGACAACAGCGCCGCGGGC ${ }^{(1)}$ & $\begin{array}{l}\text { Amplificação do } \\
\text { promotor } \mathrm{P} f e c 2\end{array}$ \\
\hline FEC2-AR & AAAGGGCCCGGAACCGCTGAGATGAGCG & Mutação em $f e c R 2$ \\
\hline FEC2-B & GATAAGCTTTCTTGGCCTGTCCGTAAGCC ${ }^{(2)}$ & $\begin{array}{l}\text { Amplificação do } \\
\text { promotor } \mathrm{P} f e c 2\end{array}$ \\
\hline FEC2-C & GATAAGCTTGGCGGCCCACAGAGCGGC ${ }^{(2)}$ & Mutação em $f e c R 2$ \\
\hline FEC2-D & GATAAGCTTGGGTTCACCATCCGCGAAACG $^{(2)}$ & Mutação em $f e c R 2$ \\
\hline FEC2-E & AGAATTCACGTCTTGACGTCGACAACCC $^{(3)}$ & Mutação em $f e c R 2$ \\
\hline FEC2-F & AGAATTCCGTTCGCCAAGGAGGGCCGG ${ }^{(3)}$ & $\begin{array}{l}\text { Amplificação do } \\
\text { promotor PtonB2 }\end{array}$ \\
\hline FEC2-G & TTGGATCCGCCAGCACCTGCAGGCCC & $\begin{array}{l}\text { Amplificação do } \\
\text { promotor PtonB2 }\end{array}$ \\
\hline FEC2-L & TTGGATCCCATCGCCTGGCCGTACGC $^{(1)}$ & Mutação em $f e c A 2$ \\
\hline FEC2-M & TGAATTCCCAGGTCCAGGTCTTCGC ${ }^{(3)}$ & Mutação em $f e c R 2$ \\
\hline FEC2-N & AGAATTCTATGGCCGTACGTTGAGC ${ }^{(3)}$ & Mutação em $f e c R 2$ \\
\hline FEC2-O & AAAAGTCGACAGCGCCTTCATGTGACGC ${ }^{(4)}$ & Mutação em $f e c R 2$ \\
\hline FEC3-A & CCCGGATCCGCTACACGGCG & $\begin{array}{l}\text { Amplificação do } \\
\text { promotor Pfec3 }\end{array}$ \\
\hline FEC3-B & TTAAAGCTTCTTGCGACGACGCAGTGCG ${ }^{(2)}$ & $\begin{array}{l}\text { Amplificação do } \\
\text { promotor Pfec3 }\end{array}$ \\
\hline FEC3-F & AGAATTCACAATTCCACCGGAAGCC ${ }^{(3)}$ & $\begin{array}{l}\text { Amplificação do } \\
\text { promotor PtonB3 }\end{array}$ \\
\hline FEC3-G & AACTGCAGGACGCCATCAGGAAACCG ${ }^{(5)}$ & $\begin{array}{l}\text { Amplificação do } \\
\text { promotor Pfec } 3\end{array}$ \\
\hline FEC4-A & ATGGATCCTGAGGGCCTGCTCCAGGGGC ${ }^{(1)}$ & $\begin{array}{l}\text { Amplificação dos } \\
\text { promotores Pfec4 e } \\
\text { PtonB4 e mutação } \\
\text { em fecR4 }\end{array}$ \\
\hline
\end{tabular}


Tabela 3. Oligonucleotídeos utilizados. (Continuação)

\begin{tabular}{|c|c|c|}
\hline Nome & Seqüiência $\left(5^{\prime}-3^{\prime}\right)^{a}$ & Propósito \\
\hline FEC4-B & GATAAGCTTCCGCCGGCGATGCAAGTCGC $^{(2)}$ & $\begin{array}{l}\text { Amplificação dos } \\
\text { promotores Pfec4 e } \\
\text { PtonB4 }\end{array}$ \\
\hline FEC4-C & AGAATTCGGCCAGATCCGAAGGCGC ${ }^{(3)}$ & Mutação em $f e c R 4$ \\
\hline FEC4-D & AGAATTCGGAACCTTCGCGCGAGCG ${ }^{(3)}$ & Mutação em $f e c R 4$ \\
\hline FEC4-E & AAAAGTCGACGTCGCCGGTCAGGTAATAGCC ${ }^{(4)}$ & Mutação em $f e c R 4$ \\
\hline FEC4-H & GATAAGCTTCACTTCGGAAAAGCCTTCCG $^{(2)}$ & Mutação em $f e c I 4$ \\
\hline FEC4-I & ATGGATCCCCTGGGCCCGGGATACCG ${ }^{(1)}$ & Mutação em fecI4 \\
\hline FEC4-J & AAGGATCCCTGGCGCAGGCTTTGGCG ${ }^{(1)}$ & Mutação em fecI4 \\
\hline FEC4-K & GGAATTCCGAAGGTTCCCGTGTCCC ${ }^{(3)}$ & Mutação em fecI4 \\
\hline $\begin{array}{l}\text { M13 Forward } \\
\qquad(-20)\end{array}$ & GTAAAACGACGGCCAG & $\begin{array}{c}\text { Reação de } \\
\text { sequenciamento e } \\
\text { PCR para } \\
\text { confirmação de } \\
\text { inserto no vetor } \\
\text { pRKlacZ290 }\end{array}$ \\
\hline M13 Reverse & CAGGAAACAGCTATGAC & $\begin{array}{c}\text { Reação de } \\
\text { sequenciamento }\end{array}$ \\
\hline LacZup & TGACGGCTACCATCA & $\begin{array}{c}\text { PCR para } \\
\text { confirmação de } \\
\text { inserto no vetor } \\
\text { pRKlacZ290 }\end{array}$ \\
\hline qRT0217f & ССТАСТTCTTCCСCTATTCGTCG & $\begin{array}{c}\text { qRT-PCR } \\
\text { (normalizador) }\end{array}$ \\
\hline qRT0217r & AAAGTCATAACCGGGCTTCAAG & $\begin{array}{c}\text { qRT-PCR } \\
\text { (normalizador) }\end{array}$ \\
\hline RT1-0559 & GCAAGGCGACCTTCCAGAACAT & qRT-PCR \\
\hline RT2-0559 & ACTCGCAATACTCGTCCAGCCA & qRT-PCR \\
\hline RT1-0682 & AGGTCGCCGGCGCTAATATG & qRT-PCR \\
\hline RT2-0682 & AGCACCAACTCTTGCTCCCCA & qRT-PCR \\
\hline RT1-1041 & CGGAACTTTGCGGCCTGACGAT & qRT-PCR \\
\hline RT2-1041 & TGCTCGACCGAGGCCGAATTGA & qRT-PCR \\
\hline
\end{tabular}


Tabela 3. Oligonucleotídeos utilizados. (Continuação)

\begin{tabular}{c|c|c} 
Nome & Seqüência (5'-3') $^{a}$ & Propósito $^{(2}$ \\
\hline RT1-1397 & CCACCACGACGGGCAATGGT & qRT-PCR \\
\hline RT2-1397 & GGCAGTCCGGCCTTGCTCAG & qRT-PCR \\
\hline RT1-1635 & GATGTCGTCGCAGAGCTGAT & qRT-PCR \\
\hline RT2-1635 & TGGTCGACCTGCCATTTCTC & qRT-PCR \\
\hline RT1-1765 & ACCTCCGCTGTGCTGAAAATCC & qRT-PCR \\
\hline RT2-1765 & GCGTAGAGGCCAAAGTCGAACA & qRT-PCR \\
\hline RT1-2200 & AGCTGCCAGTATTGTGGCTC & qRT-PCR \\
\hline RT2-2200 & CCTTGCTGAGATTGCAGGGT & qRT-PCR \\
\hline RT1-2409 & GTCTATCGCTTCGTCACCATC & qRT-PCR \\
\hline RT2-2409 & GTCGTCCTCGAAATAGAGCC & qRT-PCR \\
\hline RT1-2532 & ATGGACCTCCGCTACCAAAC & qRT-PCR \\
\hline RT2-2532 & ACAACTGCTCGGCATAGAGG & qRT-PCR \\
\hline RT1-3013 & ACGTTGACACCATTCCGCGTCT & qRT-PCR \\
\hline RT2-3013 & TGCGCAGAACGAAGTTGACCAC & qRT-PCR \\
\hline RT1-3043 & AGAAGGACTGGGCGGTCAACAA & qRT-PCR \\
\hline RT2-3043 & AGTCGGCCAGCGAGATCTTCTT & qRT-PCR \\
\hline RT1-3085 & ACAAGCAGCCTTTCCACATC & qRT-PCR \\
\hline RT2-3085 & CGTCCTGGTTACAGTGGATGA & qRT-PCR \\
\hline RT1-3399 & CGGTAAAGCAACTGACTGCC & qRT-PCR \\
\hline RT2-3399 & qRT-PCR \\
\hline
\end{tabular}

(Conclusão)

${ }^{a}$ Nucleotídeos sublinhados indicam sítios de restrição incorporados aos oligonucleotídeos: ${ }^{(1)}$ BamHI;

${ }^{(2)}$ HindIII; ${ }^{(3)}$ EcoRI; ${ }^{(4)}$ SalI; ${ }^{(5)}$ PstI.

\subsection{Construção de fusões transcricionais e ensaio de atividade de $\beta$-galactosidase}

As regiões promotoras de interesse (denominadas $\mathrm{P} f e c$ e PtonB) foram amplificadas por PCR, clonadas no vetor pGEM T-Easy (Promega) e sequenciadas. A região promotora da ORF CCNA_02790 (Pfecl) foi amplificada com os oligonucleotídeos FEC1-A e FEC1-B; da ORF CCNA_1187 (Pfec2), com os oligonucleotídeos FEC2-A e FEC2-B; da ORF CCNA_01032 (Pfec3), com FEC3-A e FEC3-B; e da ORF CCNA_00596 (Pfec4), com FEC4A e FEC4-B. A região promotora da ORF CCNA_1189 (PtonB2) foi amplificada com os 
oligonucleotídeos FEC2-F e FEC2-G, e da ORF CCNA_01034 (PtonB3), com FEC3-F e FEC3-G. O fragmento correspondente a PtonB4 é o mesmo de Pfec4 com a orientação invertida. As regiões promotoras amplificadas compreendiam aproximadamente 500-600 pb.

As reações de PCR tiveram como molde DNA genômico de C. crescentus NA1000, e continham 37,5 pmol de cada oligonucleotídeo (descritos abaixo), 0,3 $\mathrm{mM}$ de um mix de dNTPs (Invitrogen), $1 \mathrm{mM}$ de $\mathrm{MgSO}_{4}, 1 x$ PCRx Enhancer (Invitrogen) e 0,625 U de Platinum Pfx (Invitrogen), em tampão fornecido com a enzima. As condições de PCR foram de $94{ }^{\circ} \mathrm{C}$ por 3 minutos, seguidos de 30 ciclos de $94{ }^{\circ} \mathrm{C}$ por 15 segundos, $60^{\circ} \mathrm{C}$ por 30 segundos e $68^{\circ} \mathrm{C}$ por 1 minuto. Após os ciclos, a reação permaneceu a $68{ }^{\circ} \mathrm{C}$ por 7 minutos e foi mantida a 4 ${ }^{\circ} \mathrm{C}$.

Os produtos de PCR foram purificados com o QIAquick PCR Purification Kit (QIAGEN), segundo instruções do fabricante, e em seguida submetidos à reação de A-tailing, ou seja, adição de dATP nas extremidades 5' e 3' para permitir a clonagem no vetor pGEM TEasy (Promega). As reações de A-tailing continham $1 \mu \mathrm{g}$ de cada produto de PCR, 0,2 mM de dATP (Invitrogen), 1,5 mM de $\mathrm{MgCl}_{2}$ e 5 U de Taq DNA Polimerase (Invitrogen), em tampão fornecido com a enzima, num volume final de $10 \mu$ l. Estas reações foram incubadas a $70{ }^{\circ} \mathrm{C}$ por 30 minutos, e $1 \mu \mathrm{l}$ de cada foi utilizado para clonagem no vetor pGEM, segundo instruções do fabricante.

Os insertos corretos foram, então, clonados no vetor pRKlacZ290 (GOBER; SHAPIRO, 1992). As clonagens foram confirmadas por PCR e introduzidas por eletroporação em E. coli S17-1. Em seguida, os plasmídeos foram introduzidos em C. crescentus NA1000 ou linhagens derivadas através de conjugação com E. coli S17-1. Células de $C$. crescentus foram coletadas com alça de platina e semeadas em placas com meio PYE, adicionando-se uma alçada de células de $E$. coli S17-1 transformadas e incubando-se a $30{ }^{\circ} \mathrm{C}$ por 16 horas. Então, as células foram semeadas em placa PYE ágar contendo tetraciclina e ácido nalidíxico (o qual impede o crescimento de E. coli), e as placas foram incubadas a $30{ }^{\circ} \mathrm{C}$ durante três dias. A atividade do promotor das diferentes construções foi determinada por ensaios de atividade de $\beta$-galactosidase pelo método de Miller (1972).

\subsection{Construção de linhagens mutantes}

As regiões flanqueadoras das ORFs CCNA_00595 (fecR4), CCNA_00596 (fecl4), CCNA_01188 (fecR2) e CCNA_01189 (fecA2) foram amplificadas do genoma e clonadas no vetor pGEM T-Easy (Promega). As reações de PCR tiveram como molde DNA genômico de 
C. crescentus NA1000, e continham 12,5 pmol de cada oligonucleotídeo (descritos abaixo), 0,3 mM de um mix de dNTPs (Invitrogen), 5\% de dimetilsulfóxido e 0,625 U da enzima Pfu DNA Polymerase (Fermentas), em tampão fornecido com a enzima. As condições de PCR foram de $95{ }^{\circ} \mathrm{C}$ por 6 minutos, seguidos de 35 ciclos de $95^{\circ} \mathrm{C}$ por 1 minuto, $55^{\circ} \mathrm{C}$ ou $64{ }^{\circ} \mathrm{C}$ por 30 segundos e $72{ }^{\circ} \mathrm{C}$ por 2 minutos. Após os ciclos, a reação permaneceu a $72{ }^{\circ} \mathrm{C}$ por 7 minutos e foi mantida a $4^{\circ} \mathrm{C}$.

Os fragmentos flanqueadores da ORF CCNA_00595 ( $f e c R 4)$ foram amplificados com os pares de oligonucleotídeos FEC4-A/FEC4-C e FEC4-D/FEC4-E; da ORF CCNA_00596 (fecl4), com FEC4-H/I e FEC4-J/K; da ORF CCNA_01188 (fecR2), com FEC2-AR/FEC2-C e FEC2-D/FEC2-E; e da ORF CCNA_01189 (fecA2), com FEC2-L/M e FEC2-N/O. Os fragmentos amplificados compreendiam aproximadamente $800 \mathrm{pb}$.

Após clonagem no vetor pGEM T-Easy e sequenciamento, ambos os flanqueadores de cada gene foram isolados e clonados in tandem no vetor suicida pNPTS138 (D. Alley), de modo a substituir o gene de interesse por um sítio de restrição, previamente incorporado aos oligonucleotídeos. Com a introdução deste plasmídeo recombinante, pelo fato de ser um vetor suicida que não replica em $C$. crescentus, ocorre sua inserção no genoma por recombinação homóloga, sendo a deleção do gene oriunda de um segundo evento de recombinação. Assim, após a segunda recombinação, a seqüência clonada no plasmídeo permanece integrada no genoma, sendo trocada pelo gene íntegro, que fica no plasmídeo suicida.

As construções foram introduzidas em C. crescentus NA1000 por conjugação, e a seleção dos eventos de recombinação foi realizada como descrito em Galhardo et al. (2005). Todas as deleções foram feitas em fase, para evitar a ocorrência de efeito polar sobre genes adjacentes. As deleções dos genes $f e c R 2$ e $f e c R 4$ foram analisadas para verificar se restariam códons que ainda permitissem a interação com o fator sigma, por comparação com a proteína FecR de E. coli (ENZ et al., 2000), através de alinhamento realizado com o programa ClustalW2 (LARKIN et al., 2007); chegou-se à conclusão que estas regiões de interação não estariam presentes nos mutantes construídos.

\subsection{Curvas de crescimento e testes de sobrevivência}

Culturas de NA1000, $\Delta f e c R 2, \Delta f e c R 4, \Delta f e c A 2$ e $\Delta f e c I 4$ foram inoculadas em meio PYE líquido e incubadas por 16 horas a $30{ }^{\circ} \mathrm{C}$. Estas foram diluídas para uma densidade óptica a $600 \mathrm{~nm}\left(\mathrm{DO}_{600}\right)$ igual a 0,1 e divididas em duas alíquotas. Uma foi mantida em PYE e 
à outra foram acrescentados $100 \mu \mathrm{M}$ do quelante de ferro 2,2'-dipiridil. $\mathrm{O}$ crescimento das culturas foi monitorado pela medição da $\mathrm{DO}_{600}$ em diferentes tempos de incubação.

Curvas de crescimento também foram feitas desta maneira em meio mínimo M2 contendo diferentes fontes de ferro. As mesmas linhagens, inoculadas em meio M2, tiveram o volume necessário centrifugado para obter uma diluição a $\mathrm{DO}_{600}$ igual a 0,1 . O precipitado de células foi ressuspendido em meio M2 (cuja fonte de ferro é $100 \mu \mathrm{M}$ de $\mathrm{FeSO}_{4}$ ); M2 substituindo $\mathrm{FeSO}_{4}$ por $100 \mu \mathrm{M}$ de citrato férrico; ou M2 substituindo $\mathrm{FeSO}_{4}$ por $100 \mu \mathrm{M}$ de cloreto de hemina. A curva de crescimento foi determinada como acima.

Para se avaliar a utilização do sideróforo ferricromo após limitação de ferro, a linhagem NA1000 foi inoculada em meio NB ("nutrient broth") e diluída para uma $\mathrm{DO}_{600}$ igual a 0,05. Ao atingir uma $\mathrm{DO}_{600}$ de 0,2, a cultura foi dividida em alíquotas: três tiveram adição de 2,2' -dipiridil (para uma concentração final de 50, 100 ou $200 \mu \mathrm{M}$ ), uma teve adição de apo-enterobactina (isto é, enterobactina sem ferro associado) $(100 \mu \mathrm{M})$ e uma permaneceu como controle. O crescimento foi monitorado como acima. Após 18 horas, as culturas foram divididas em dois tubos, e ferricromo foi adicionado a uma das amostras para uma concentração final de $10 \mu \mathrm{M}$. A outra amostra permaneceu com o quelante, para comparação da densidade óptica final.

A avaliação do crescimento também foi feito em meio mínimo M2 contendo $\gamma$ ciclodextrina (Sigma-Aldrich Brasil Ltda., São Paulo, SP, Brasil). A solução estoque deste composto $(25 \mathrm{mM})$ foi preparada em $1 \mathrm{M} \mathrm{NH}_{4} \mathrm{OH}$. Culturas em M2 de C. crescentus foram centrifugadas e o precipitado de células foi lavado duas vezes com água destilada estéril para remover o meio residual. Então, foi adicionado meio M2 sem glicose contendo $\gamma$ ciclodextrina $(0,1 \%)$ para uma $\mathrm{DO}_{600}$ de 0,15 . As culturas foram incubadas em placas de 12 poços no aparelho SpectraMax Paradigm Multi-Mode Microplate Detection Platform (Molecular Devices, LLC, Sunnyvale, CA, EUA), a $29^{\circ} \mathrm{C}$ com agitação orbital. A $\mathrm{DO}_{600}$ foi medida a cada 15 minutos por 24 horas com o software SoftMax Pro 6.2.1 (Molecular Devices).

A resistência das linhagens $\Delta f e c R 2$ e $\Delta f e c R 4$ a peróxido de hidrogênio $\underline{(3 \%)}$ foi avaliada por ensaio de inibição de crescimento em placas, como descrito em da Silva Neto et al. (2009). As linhagens NA1000, $\Delta f e c R 2$ e $\Delta f e c R 4$ foram inoculadas em meio PYE líquido, diluídas para uma $\mathrm{DO}_{600}$ igual a 0,1 e, ao chegar a uma $\mathrm{DO}_{600}$ próxima de 0,5 , foram semeadas em placas de PYE ágar. Após a secagem, posicionou-se um disco de papel filtro 3MM (Whatman PLC, Maidstone, Kent, Inglaterra) estéril no centro da placa, ao qual foram 
aplicados $10 \mu \mathrm{l}$ de peróxido de hidrogênio $3 \%$. Incubaram-se as placas a $30{ }^{\circ} \mathrm{C}$ durante dois dias. O ensaio foi repetido após 24 e 48 horas de crescimento das culturas.

\subsection{Testes de utilização de sideróforos}

Sideróforos pertencentes à categoria dos catecóis (agrobactina, corinebactina, enterobactina e vibriobactina) foram preparados dissolvendo $1 \mu \mathrm{mol}$ em $250 \mu 1$ de metanol, 1 $\mathrm{mM} \mathrm{FeSO}{ }_{4}$ e $25 \mathrm{mM} \mathrm{NaHPO}_{4} \mathrm{pH}$ 6,9, para um volume final de $1 \mathrm{ml}$. A mistura foi incubada em gelo por uma hora e a pureza das amostras foi averiguada através de uma varredura em espectofotômetro nos comprimentos de onda de 350 a $700 \mathrm{~nm}$. Sideróforos da categoria dos hidroxamatos foram preparados através de sua dissolução em água destilada estéril para uma concentração estoque de $1 \mathrm{mM}$; no caso de ferricromo A, $30 \mathrm{mM} \mathrm{NaOH}$ também foram adicionados.

Culturas de $C$. crescentus foram incubadas por 16 horas em meio NB e diluídas para uma $\mathrm{DO}_{600}$ de 0,1 . Ao alcançar uma $\mathrm{DO}_{600}$ de $0,3,200 \mu \mathrm{l}$ das culturas foram semeados em 20 $\mathrm{ml}$ de meio NB semissólido contendo 2,2'-dipiridil $(200 \mu \mathrm{M})$ ou apo-enterobactina $(100 \mu \mathrm{M})$ como quelantes de ferro. A seguir, discos de filtros de papel (diâmetro de $6 \mathrm{~mm}$ ) contendo 10 $\mu \mathrm{l}$ de sideróforo $(50 \mu \mathrm{M})$ foram aplicados na superfície do meio. As placas foram incubadas a $30{ }^{\circ} \mathrm{C}$ por 24 horas. $\mathrm{O}$ crescimento bacteriano foi avaliado na forma de halos ao redor dos discos de papel.

Alternativamente, o ensaio foi realizado em placas de seis poços, utilizando $100 \mu \mathrm{lde}$ cultura e $3 \mathrm{ml}$ de meio NB semissólido.

\subsection{Microarranjos de cDNA e validação}

O RNA total das linhagens NA1000, $\Delta f e c R 2$ e $\Delta f e c R 4$ foi extraído de culturas em fase logarítmica em meio $\mathrm{M} 2\left(\mathrm{DO}_{600}\right.$ de aproximadamente 1,0$)$, utilizando o reagente Trizol (Invitrogen Brasil, São Paulo, SP, Brasil) (CHOMCZYNSKI; SACCHI, 1987). Cada amostra de RNA (tratado com DNAse I, Thermo Fisher Scientific Inc., Waltham, MA, EUA) foi utilizada em duplicata para gerar cDNA, utilizando o FairPlay III Microarray Labeling Kit (Agilent Technologies, Inc., Santa Clara, CA, EUA). O cDNA das amostras correspondentes a NA1000 foi marcado com o corante Cy3 Monofunctional Reactive Dye (Q13108, GE Healthcare do Brasil Ltda., São Paulo, SP, Brasil), e o cDNA das amostras correspondentes às 
linhagens mutantes foi marcado com o corante Cy5 Monofunctional Reactive Dye (Q15108, GE Healthcare).

Foram realizadas quatro hibridizações, sendo duas referentes a NA1000 x $\Delta f e c R 2 \mathrm{e}$ duas referentes a NA1000 x $\Delta f e c R 4$, em lâmina de microarranjo 4x44K customizada para Caulobacter (Agilent Technologies). A lâmina foi acondicionada em forno de hibridização por 24 horas a $65^{\circ} \mathrm{C}$ e $10 \mathrm{rpm}$. Após a hibridização, a lâmina foi lavada por 5 minutos com SSC 1x, SDS 0,2\%; mais 5 minutos com SSC 0,1x, SDS 0,2\%; acetonitrila e Stabilization and Drying Solution (Agilent Technologies) por 30 segundos. A leitura das fluorescências contidas na lâmina foi feita no aparelho SureScan Microarray Scanner (Agilent Technologies), e o software Feature Extraction (Agilent Technologies) foi utilizado para gerar os valores de expressão relativa em cada experimento.

Como a lâmina específica para Caulobacter inclui oligonucleotídeos correspondentes a regiões não transcritas, apenas as informações referentes a oligonucleotídeos hibridizando em regiões codificadoras foram levadas em conta (em geral, os 4 últimos oligonucleotídeos relativos a cada ORF). Para ser considerado induzido, um gene precisaria apresentar os quatro últimos oligonucleotídeos com valores de Cy5/Cy3 (mutante/NA1000) maiores que 2,0 em todas as réplicas.

Treze genes foram escolhidos para validação do microarranjo por PCR quantitativo em tempo real (qRT-PCR). As reações foram feitas com $50 \mathrm{ng}$ de cDNA, $0,1 \mu \mathrm{M}$ dos oligonucleotídeos específicos para cada gene e o kit Maxima SYBR Green/ROX qPCR Master Mix (Thermo Fisher). As condições utilizadas foram: $50{ }^{\circ} \mathrm{C}$ por 2 minutos; $95{ }^{\circ} \mathrm{C}$ por 2 minutos; 40 ciclos de $95{ }^{\circ} \mathrm{C}$ por 15 segundos; $60{ }^{\circ} \mathrm{C}$ por 1 minuto. A análise da fluorescência emitida na PCR em tempo real foi feita utilizando o 7500 System SDS Software v.1.2.2 (Applied Biosystems do Brasil, São Paulo, SP, Brasil). Os níveis de expressão relativa foram calculados utilizando o método do $2^{-\Delta \Delta \mathrm{Ct}}$ (LIVAK; SCHMITTGEN, 2001), tendo como normalizador a ORF CCNA_00217.

\subsection{Predição computacional de promotores}

Para identificar um possível consenso do promotor reconhecido pelo fator sigma FecI4, seis ORFs induzidas no mutante $\Delta f e c R 4$ e validadas por qRT-PCR foram utilizadas. Para isso, sequiências a montante de cada ORF foram analisadas em busca do primeiro oligonucleotídeo observado no microarranjo com expressão relativa alta no mutante (ou seja, a partir de que ponto do genoma o RNA mensageiro presumivelmente começa a ser transcrito 
no mutante). Deste ponto, foram contadas 50 bases a montante, e esta região de 50 nucleotídeos foi utilizada como ponto de partida para a busca de promotores. Para as seis ORFs, estas regiões foram analisadas e alinhadas pela ferramenta MEME (BAILEY et al., 2009); disponível em http://meme.sdsc.edu/meme/cgi-bin/meme.cgi) em busca de motivos em comum. O motivo gerado pela ferramenta MEME mais condizente com um promotor foi analisado com o módulo "DNA-pattern" da ferramenta RSAT (Regulatory Sequence Analysis Tools, disponível em http://rsat.ulb.ac.be/) (THOMAS-CHOLLIER et al., 2008), em busca de sítios semelhantes em outras regiões do genoma de C crescentus, permitindo até uma substituição.

\subsection{Microarranjos fenotípicos}

Com a finalidade de se observar o crescimento de $C$. crescentus em uma grande variedade de compostos simultaneamente, foram utilizadas as microplacas Phenotype MicroArrays for Microbial Cells (Biolog, Inc., Hayward, CA, EUA; modelos PM1 e PM2A). Culturas incubadas em M2 foram centrifugadas, o precipitado foi lavado duas vezes com água destilada estéril, e as células foram ressuspendidas em meio M2 sem glicose, para que a única fonte de carbono no meio fosse aquela contida no poço da microplaca. As microplacas com cultura foram incubadas no aparelho SpectraMax Paradigm Multi-Mode Microplate Detection Platform (Molecular Devices), a $29^{\circ} \mathrm{C}$ com agitação orbital média. A DO 600 foi medida a cada 15 minutos por 24 horas com o software SoftMax Pro 6.2.1 (Molecular Devices). 


\section{RESULTADOS E DISCUSSÃO}

\subsection{Genes e promotores em estudo}

Para maior clareza, os quatro conjuntos de genes compreendendo fator sigma, antissigma e receptor dependente de TonB (sistemas FEC) foram denominados FEC1 (CCNA_02790-1-2), FEC2 (CCNA_01187-8-9), FEC3 (CCNA_01032-3-4) e FEC4 (CCNA_00595-6-7), sendo o gene mais semelhante a fecI de E. coli o pertencente a FEC1, e o mais divergente o pertencente a FEC4 (VISCA et al., 2002). Para fins de identificação neste trabalho, cada gene teve um número acrescido a seu nome, de modo a corresponder ao sistema FEC ao qual pertence (por exemplo: o gene ortólogo a fecR do sistema FEC2 foi denominado $f e c R 2$ ). A figura 6 mostra os genes e promotores analisados neste trabalho.

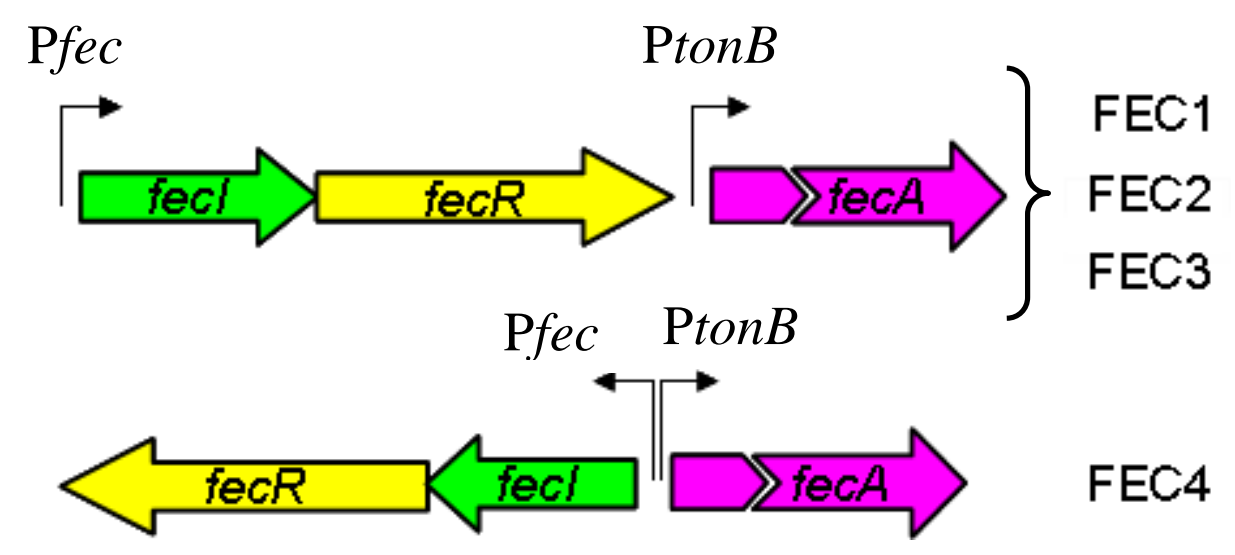

Figura 6 - Representação esquemática das regiões do genoma de Caulobacter crescentus NA1000 analisadas neste trabalho. As setas maiores indicam os quadros abertos de leitura, com as respectivas orientações de transcrição. As setas verdes representam os genes codificando fatores sigma putativos de carência de ferro; as setas amarelas, os anti-sigmas; e as setas rosa, os receptores dependentes de TonB. As setas dobradas identificam as regiões promotoras analisadas neste trabalho. Cada um desses quatro conjuntos de genes foi identificado com a abreviação FEC. Para fins de identificação neste trabalho, cada gene teve um número acrescido a seu nome, de modo a corresponder ao sistema FEC ao qual pertence (por exemplo: o gene ortólogo a $f e c R$ do sistema FEC2 foi denominado $f e c R 2$ ). Os quadros abertos de leitura e o espaçamento entre eles estão representados aproximadamente em escala, exceto pelas setas quebradas, que indicam um tamanho maior. 
Dos quatro sistemas FEC de C. crescentus, três (FEC1, FEC2 e FEC3) apresentam os genes codificando o fator sigma, o antissigma e o receptor dependente de TonB no mesmo sentido de transcrição, nesta ordem. Já o sistema FEC4 possui os genes ortólogos a fecI e $f e c R$ no mesmo sentido de transcrição, e $f e c A$ em sentido oposto a $f e c I$ (Fig. 6). Este trabalho iniciou-se com o estudo dos quatro sistemas FEC de C. crescentus de modo geral, para então ter maior aprofundamento sobre os sistemas FEC2 e FEC4.

\subsection{Análise da expressão dirigida pelos promotores}

Ao contrário do descrito para outros sistemas bacterianos, os genes ortólogos aos fec em $C$. crescentus não possuem sítios de ligação preditos do regulador de transcrição Fur, mas isso não significa que eles não respondam a variações nas concentrações de ferro. Como forma de obter um panorama geral das condições de expressão dos sistemas FEC de $C$. crescentus, primeiramente analisou-se a resposta destes sistemas a variações nas concentrações de ferro em $C$. crescentus. Os promotores à frente dos genes ortólogos a fecI de C. crescentus ( $\mathrm{P} f e c)$ foram amplificados por PCR e clonados no vetor pRKlacZ290, criando uma fusão transcricional do promotor de interesse com o gene repórter lac $Z$, que codifica a enzima $\beta$-galactosidase. Como este gene se encontra sem promotor neste plasmídeo, sua transcrição será dirigida pelo promotor clonado à sua frente. É possível medir a atividade desta enzima através de um ensaio colorimétrico, medindo assim a expressão do gene correspondente ao promotor inserido.

Uma vez inseridos nos plasmídeos, os promotores Pfec tiveram a expressão analisada por ensaios de atividade de $\beta$-galactosidase, em meio rico PYE suplementado com citrato férrico ou o quelante de ferro 2,2'-dipiridil, que simula uma condição de carência de ferro. De acordo com o modelo de regulação mediada por ferro em E. coli, o citrato férrico não induz diretamente a expressão dos fatores sigma, mas a carência de ferro inibe a ação do repressor Fur, desreprimindo a expressão daqueles genes. No entanto, os resultados apresentados na figura 7A mostram que este não é o caso em C. crescentus, visto que não houve indução (ou desrepressão) significativa dos genes na condição de carência de ferro. Ainda, foi observado que estes promotores não respondem diretamente à disponibilidade de ferro no meio, pois a expressão de cada gene foi semelhante tanto na presença quanto na ausência de ferro.

É interessante observar que o promotor $\mathrm{P} f e c 4$ apresenta níveis de expressão menores que os dos outros promotores analisados, abaixo de 500 unidades Miller (Fig. 7A). Este promotor se encontra em uma região do genoma que também contém o promotor do gene 
fecA4, codificando o receptor dependente de TonB adjacente, porém em sentido contrário (Fig. 6). É possível que haja uma tendência ao favorecimento da transcrição dirigida pelo promotor PtonB4 em detrimento daquela dirigida por $\mathrm{P} f e c 4$, talvez por se tratar de um promotor cuja sequência possui mais afinidade pelo fator sigma responsável por sua transcrição.

Também foram realizados ensaios utilizando outras fontes de ferro (sulfato ferroso e cloreto de hemina), e novamente não foram observadas diferenças na expressão dos genes na presença ou na ausência destas fontes de ferro (Fig. 7B e 7C). Adicionalmente, foi empregada uma linhagem mutante para o gene fur (DA SILVA NETO et al., 2009), para verificar se os genes de fatores sigma ortólogos a fecI de C. crescentus têm a transcrição reprimida por Fur, como ocorre em outras bactérias. Entretanto, este não parece ser o caso em C. crescentus, visto que a expressão dos promotores não é significativamente induzida (ou desreprimida) no mutante $\Delta$ fur (Fig. 7B e 7C). Para se ter certeza da eficácia do 2,2'-dipiridil como quelante de ferro no ensaio, um controle positivo foi empregado, consistindo na fusão de transcrição do gene lacZ com o promotor do gene CCNA_02277, comprovadamente sujeito à repressão por Fur (DA SILVA NETO et al., 2009) (Fig. 7B, inserto). 
Figura 7 - Expressão derivada dos promotores à frente de genes codificando fatores sigma do tipo FecI em C. crescentus. Ensaios de atividade de $\beta$-galactosidase realizados em meio PYE, duas horas após a adição dos compostos a culturas em fase exponencial. (A) Citrato férrico $(1 \mathrm{mM})$ foi utilizado como fonte de ferro, e o quelante de ferro 2,2'-dipiridil $(100 \mu \mathrm{M})$ foi utilizado como simulação de uma condição de carência deste metal. O vetor pRKlacZ290 sem inserto foi utilizado como controle negativo. (B) Ensaio utilizando sulfato ferroso $(100 \mu \mathrm{M})$ como fonte de ferro, nas linhagens NA1000 e $\Delta$ fur. O quadro pequeno à direita mostra o controle positivo, com uma fusão transcricional do gene lacZ com o promotor de CCNA_02277 (um gene codificando um receptor dependente de TonB, cuja expressão é sabidamente induzida sob carência de ferro e desreprimida no mutante $\Delta$ fur) (DA SILVA NETO et al., 2009). (C) Ensaio utilizando cloreto de hemina $(100 \mu \mathrm{M})$ como fonte de ferro, nas linhagens NA1000 e $\Delta$ fur. Os resultados são expressos em unidades Miller e representam a média de três experimentos independentes. As barras pretas indicam o desvio padrão. 


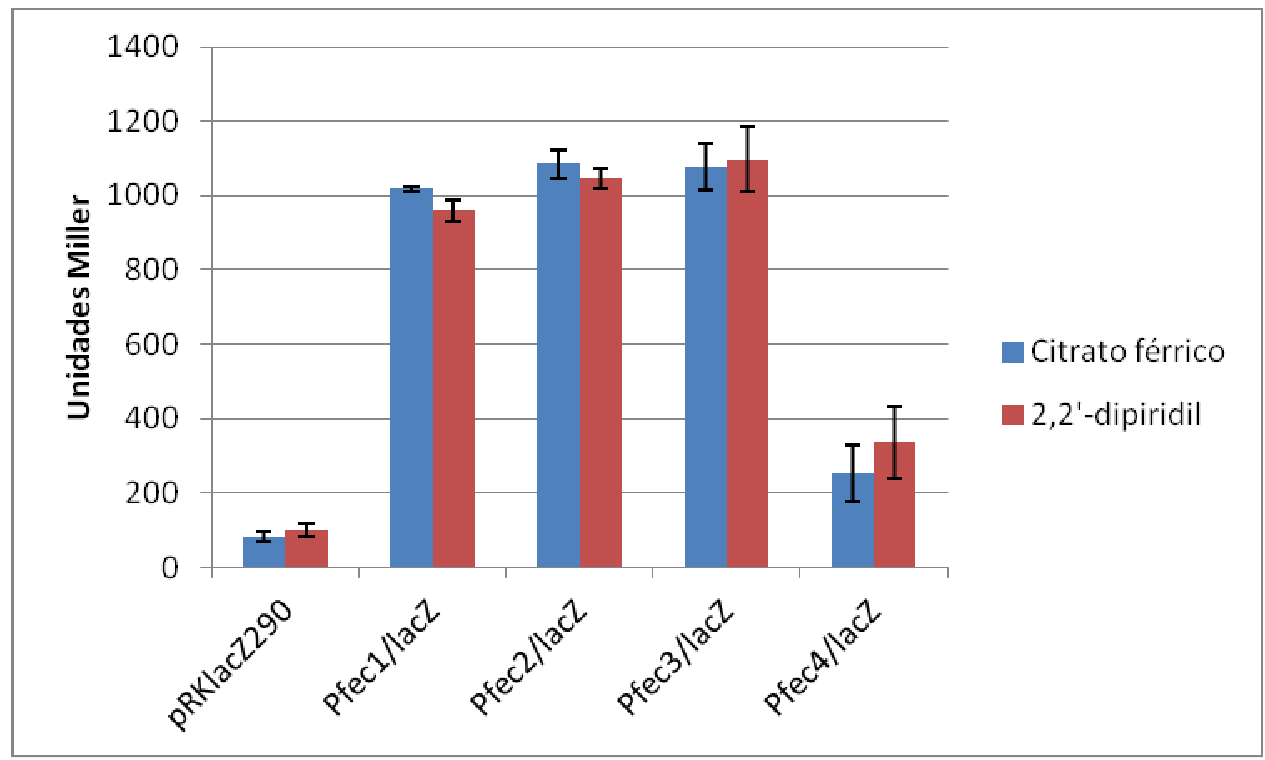

(A)

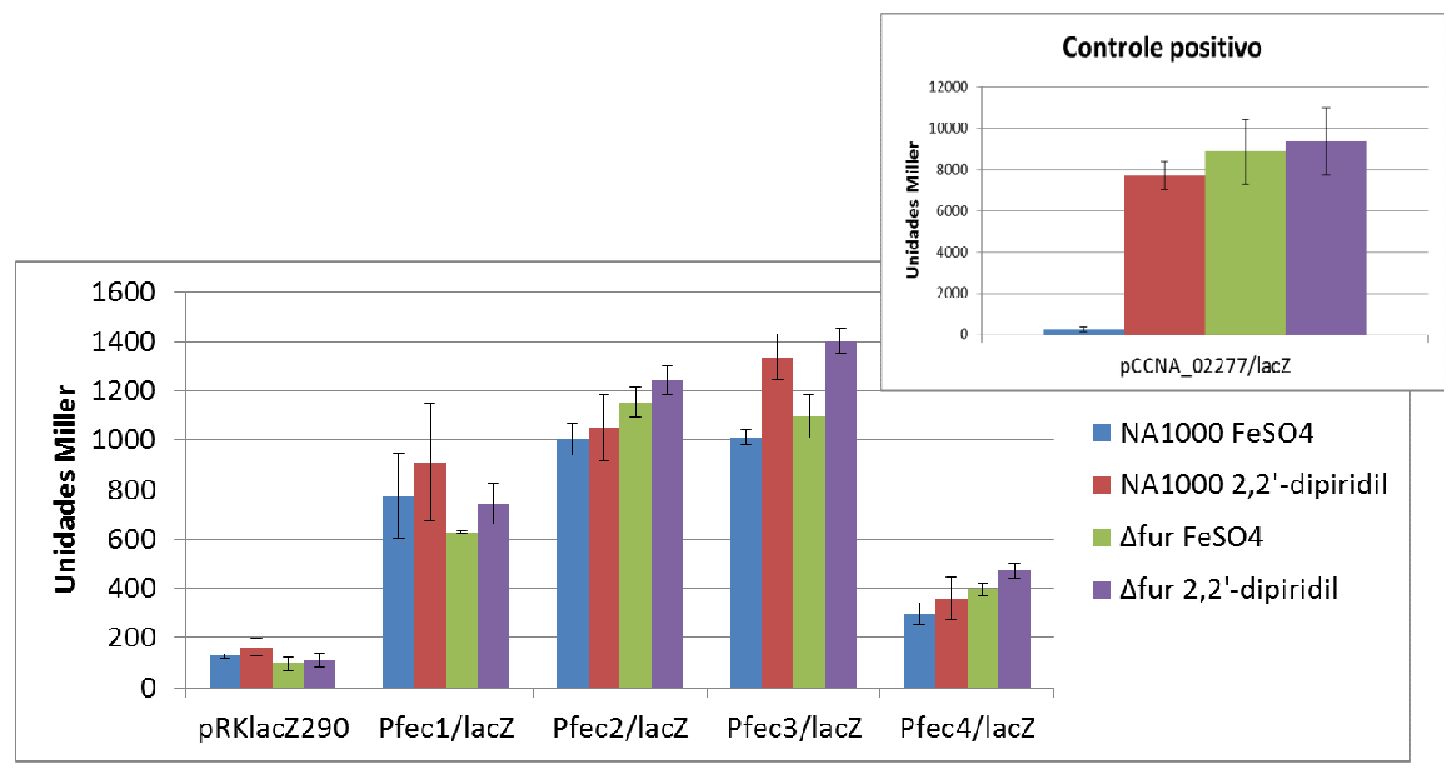

(B)

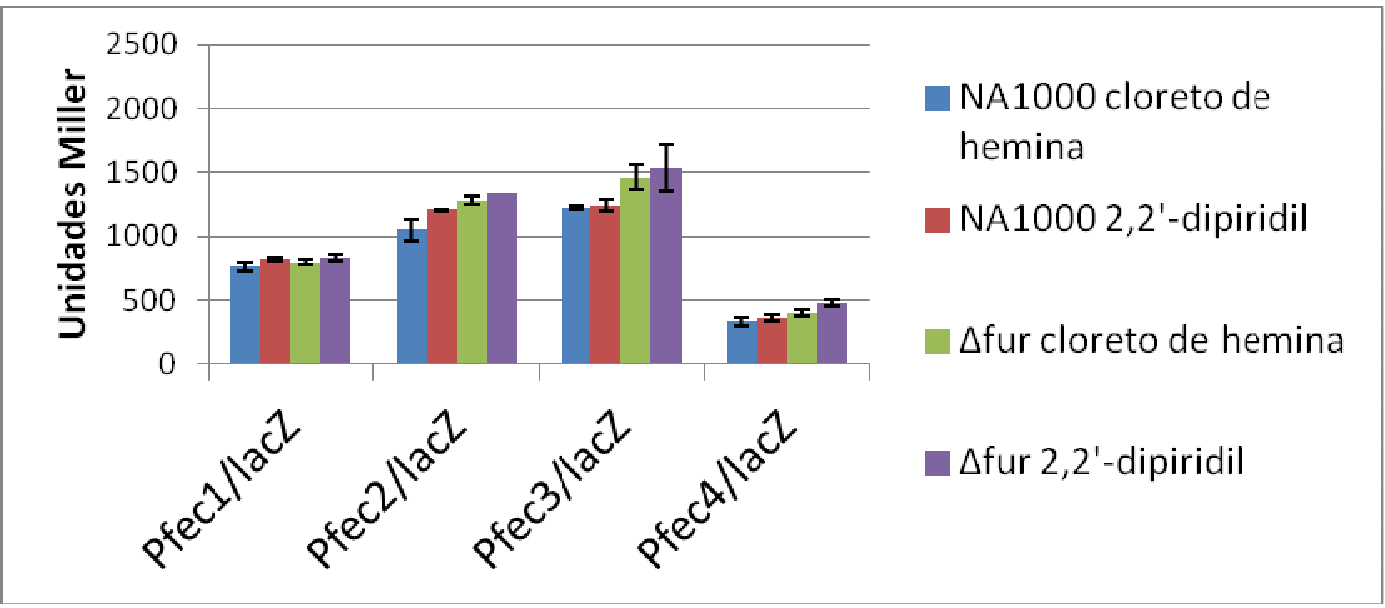

(C) 
Os resultados obtidos corroboram a observação de que os genes codificando fatores sigma semelhantes a fecI em $C$. crescentus não são regulados por Fur (DA SILVA NETO et al., 2009). Esta é uma importante diferença em relação aos modelos de regulação mediada por ferro em outras bactérias. Além disso, o fato de os sistemas FEC analisados não responderem à carência de ferro também caracterizaria uma exceção à regra. Já foi observado que os sistemas FEC de $C$. crescentus não possuem sítios de ligação nem de Fur nem de outros reguladores da homeostase de ferro ou manganês presentes em diversas bactérias, como IscR, MntR, Mur, Irr e RirA (RODIONOV et al., 2006), tendo sido classificados como "de regulação incerta”. Apesar disso, esta característica não se aplica a todas as $\alpha$-proteobactérias, uma vez que Rhodospirillum rubrum possui sítios de ligação a Fur a montante dos genes ortólogos a fecIRA (RODIONOV et al., 2006).

Visando a uma análise mais direta das condições de indução dos sistemas FEC de $C$. crescentus, partiu-se para o estudo da expressão dos genes codificando receptores dependentes de TonB pertencentes a estes sistemas. A expressão das fusões transcricionais PtonB/lacZ foi avaliada em condições de excesso e carência de ferro, como o já realizado para as fusões Pfec/lacZ, e da mesma forma, nenhum dos genes analisados tem a expressão alterada na presença de sulfato ferroso, citrato férrico ou 2,2'-dipiridil (Fig. 8). A fusão PtonB1/lacZ não pôde ser obtida e portanto não foi incluída nas análises. Estes resultados fornecem indícios de que os sistemas FEC de C. crescentus podem não estar envolvidos com a homeostase de ferro nesta bactéria.

Os promotores descritos também foram analisados em termos de sua resposta à presença de um sideróforo no meio. $\mathrm{O}$ ensaio foi realizado incubando-se as culturas de NA1000 portando as fusões transcricionais até o meio da fase exponencial, adicionando-se o sideróforo ferricromo e analisando a expressão derivada dos promotores após duas horas de exposição ao sideróforo. Como se pode observar na figura 9, nenhuma das fusões transcricionais respondeu à adição de ferricromo. Esta é mais uma indicação de que os genes pertencentes aos sistemas FEC de C. crescentus não respondem a ferro. 


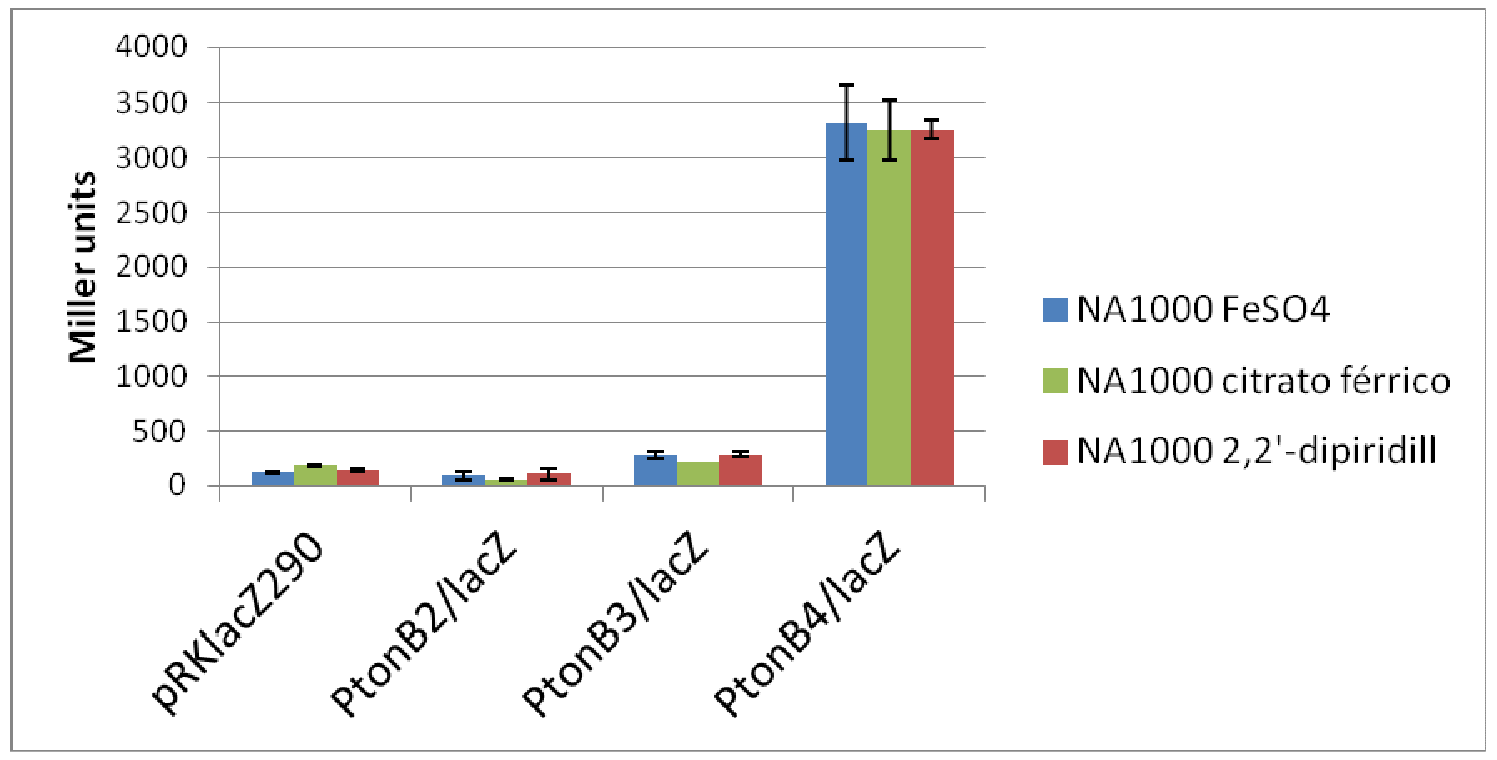

Figura 8 - Análise da expressão dos promotores PtonB sob excesso ou carência de ferro. Ensaios de atividade de $\beta$-galactosidase realizados em meio PYE, duas horas após a adição dos compostos a culturas em fase exponencial (citrato férrico, $1 \mathrm{mM} ; \mathrm{FeSO}_{4}$ e 2,2'-dipiridil, $100 \mu \mathrm{M}$ ). O vetor pRKlacZ290 sem inserto foi utilizado como controle negativo. Os resultados são expressos em unidades Miller e representam a média de dois experimentos independentes. As barras pretas indicam o desvio padrão.

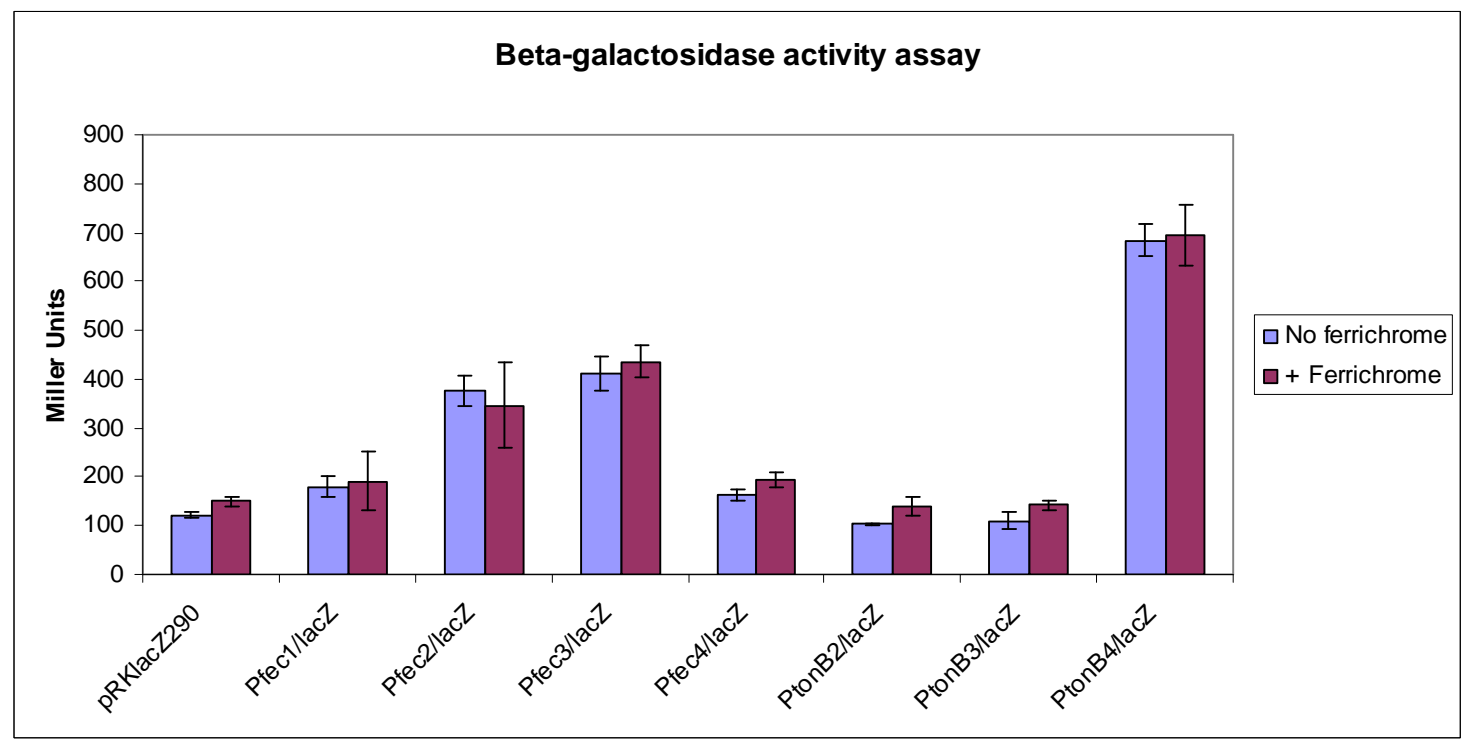

Figura 9 - Análise de expressão dos promotores na presença do sideróforo ferricromo. Culturas de NA1000 portando as fusões de promotores designadas foram incubadas até o meio da fase exponencial; ferricromo $(50 \mu \mathrm{M})$ foi adicionado e as culturas foram incubadas por mais duas horas antes da realização do ensaio. Os valores representam a média de dois experimentos, cada um com duas replicatas técnicas. As barras pretas indicam o desvio padrão. 
A seguir, foram realizados ensaios de expressão em linhagens mutantes para os genes $f e c R 2$ e $f e c R 4$. Os oligonucleotídeos utilizados para amplificar os flanqueadores dos genes $f e c R 2$ e $f e c R 4$ (codificando antissigmas) foram desenhados de modo a gerar uma deleção em fase, para evitar eventuais efeitos polares. Para assegurar que os resíduos de aminoácidos remanescentes nos mutantes não permitam a provável interação com o fator sigma correspondente, foi realizado um alinhamento dos quatro anti-sigmas com o anti-sigma FecR de E. coli, utilizando o programa ClustalW2 (LARKIN et al., 2007). De acordo com Enz et al. (2000), a região de FecR que contém os resíduos de aminoácidos 9-58 é a que permite a interação com FecI. Comparando-se a posição destes resíduos em FecR e nos antissigmas de C. crescentus no alinhamento, verificou-se que as regiões similares à região de interação não estarão presentes após a deleção dos genes (dados não mostrados).

Se um destes fatores sigma estiver envolvido com a expressão do promotor PtonB correspondente, espera-se que a expressão deste promotor aumente quando o fator sigma tem sua atividade aumentada, o que pode ser simulado através da mutação do respectivo antissigma. Então, a fusão PtonB2/lacZ foi introduzida em uma linhagem mutante para o gene $f e c R 2$. A expressão derivada do promotor foi avaliada na presença de sulfato ferroso ou 2,2'dipiridil (Fig. 10A). Resultados similares foram observados em meio contendo citrato férrico (dados não mostrados). Observou-se que a expressão de PtonB2/lacZ é quase 6 vezes maior no mutante para o antissigma correspondente, como esperado. Logo, pode-se afirmar que a expressão de PtonB2 é dependente do fator sigma FecI2, que apresenta maior atividade na ausência do antissigma correspondente. A fusão PtonB2/lacZ também teve sua expressão avaliada no mutante $\Delta f e c R 4$, para verificar se há efeito cruzado de FecI4 sobre este promotor, e os níveis de expressão se mostraram extremamente baixos, como acontece em NA1000 (dados não mostrados); assim, concluímos que a expressão de PtonB2 é especificamente dependente de FecI2, e não há reconhecimento do promotor pelo fator sigma ECF FecI4.

A mesma abordagem foi empregada em relação à fusão PtonB4/lacZ. Todavia, não houve aumento de expressão deste promotor no mutante $\Delta f e c R 4$, e sim uma diminuição da expressão (Fig. 10B). Isto indica que, ao contrário do observado para PtonB2, PtonB4 não tem sua expressão regulada pelo fator sigma FecI4. Uma possibilidade é a de que o antissigma seja necessário para a atividade do fator sigma, algo que já foi observado em Escherichia coli (ENZ et al., 2000; OCHS et al., 1995; STIEFEL et al., 2001). Apesar de o antissigma FecR inibir a atividade do fator sigma FecI na ausência de citrato férrico (atividade antissigma), foi visto que FecR aumenta a atividade de FecI na presença do composto férrico (atividade "prósigma”). A atividade pró-sigma também foi vista nas proteínas FoxR e FiuR de Pseudomonas 
aeruginosa (METTRICK; LAMONT, 2009). Esta noção aparentemente contraditória poderia ser explicada pela hipótese de FecR aumentar a afinidade de FecI pelo cerne da RNA polimerase quando a expressão de receptores é necessária, ou é possível que FecR aja como chaperone, protegendo FecI da degradação (MAHREN; ENZ; BRAUN, 2002). Por causa dessa ambiguidade de funções, estes antissigmas são denominados por alguns autores como "reguladores de fatores sigma" (METTRICK; LAMONT, 2009).

Genes semelhantes a fecI geralmente estão associados em clusters contendo os respectivos ortólogos de $f e c R$ e $f e c A$ (VISCA et al., 2002). Em C. crescentus, fecI4 se encontra adjacente a $f e c R 4$ e $f e c A 4$, permitindo que se assuma que este último seja o receptor dependente de TonB associado a este sistema. No entanto, conforme o resultado apresentado na figura 10B, este não é o caso, pois não houve uma indução do promotor PtonB4 no mutante $\Delta f e c R 4$, o que seria esperado devido à ativação constitutiva de FecI4 neste mutante. Isto sugere que fecA4 não é regulado por FecI4 e que não participa da via regulatória deste fator sigma, apesar da proximidade entre os genes. Dado que $C$. crescentus possui um notável número de genes codificando receptores dependentes de TonB (NIERMAN et al., 2001), é possível que outro receptor participe desta via regulatória.

Os dados apresentados mostram que a expressão de PtonB2, mas não a de PtonB4, é induzida na ausência do antissigma correspondente. Acredita-se que isso se deva a uma maior atividade do fator sigma FecI2 e ao consequente aumento da transcrição do gene codificando o receptor dependente de TonB. No entanto, não se pode descartar a hipótese de haver uma regulação distinta sobre PtonB2, pois os níveis de expressão apresentados em NA1000 são extremamente baixos (Fig. 10A).

Verificou-se também se existe ou não autorregulação nos sistemas FEC de $C$. crescentus. A premissa considerada é a de que o fator sigma (FecI2 ou FecI4) está constitutivamente ativo na linhagem mutante para o antissigma correspondente. Se este fator sigma for autorregulado (isto é, se ele reconhecer seu próprio promotor), se esperaria que a expressão de seu próprio gene se encontrasse induzida no mutante $\Delta f e c R$ correspondente. 


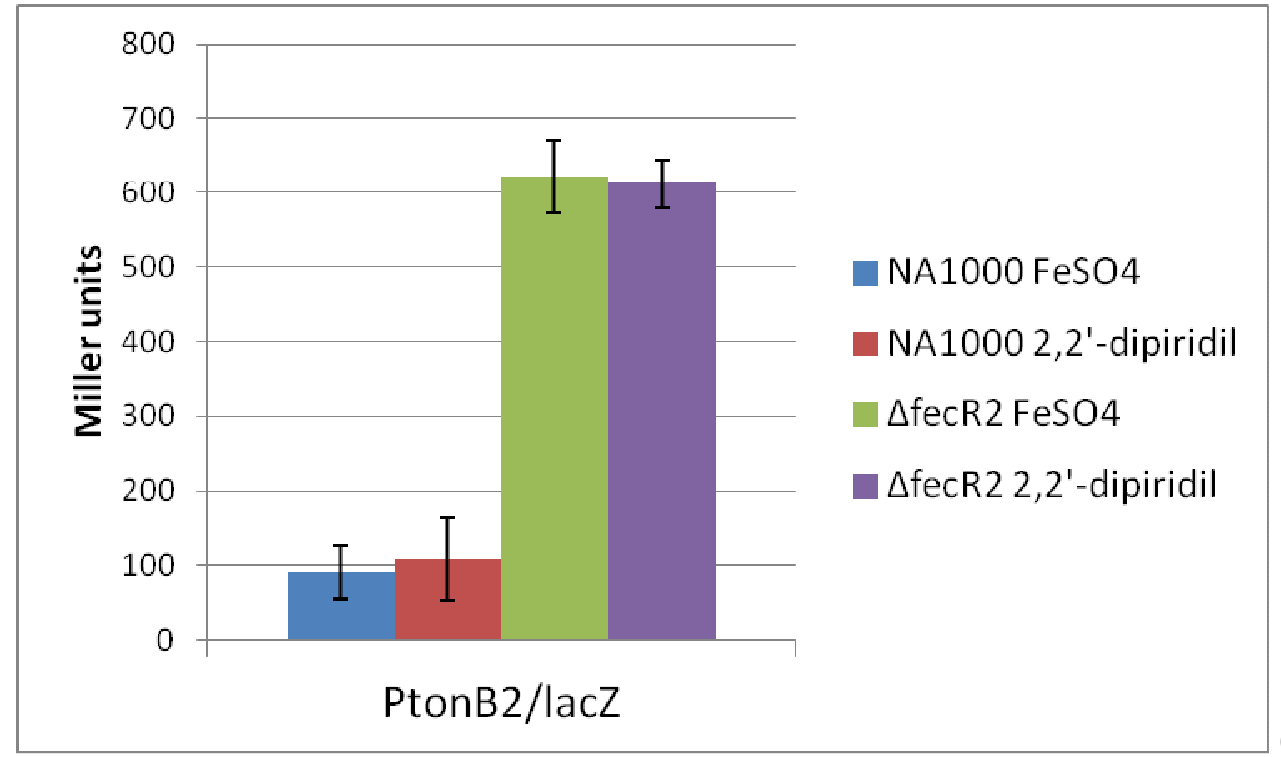

(A)

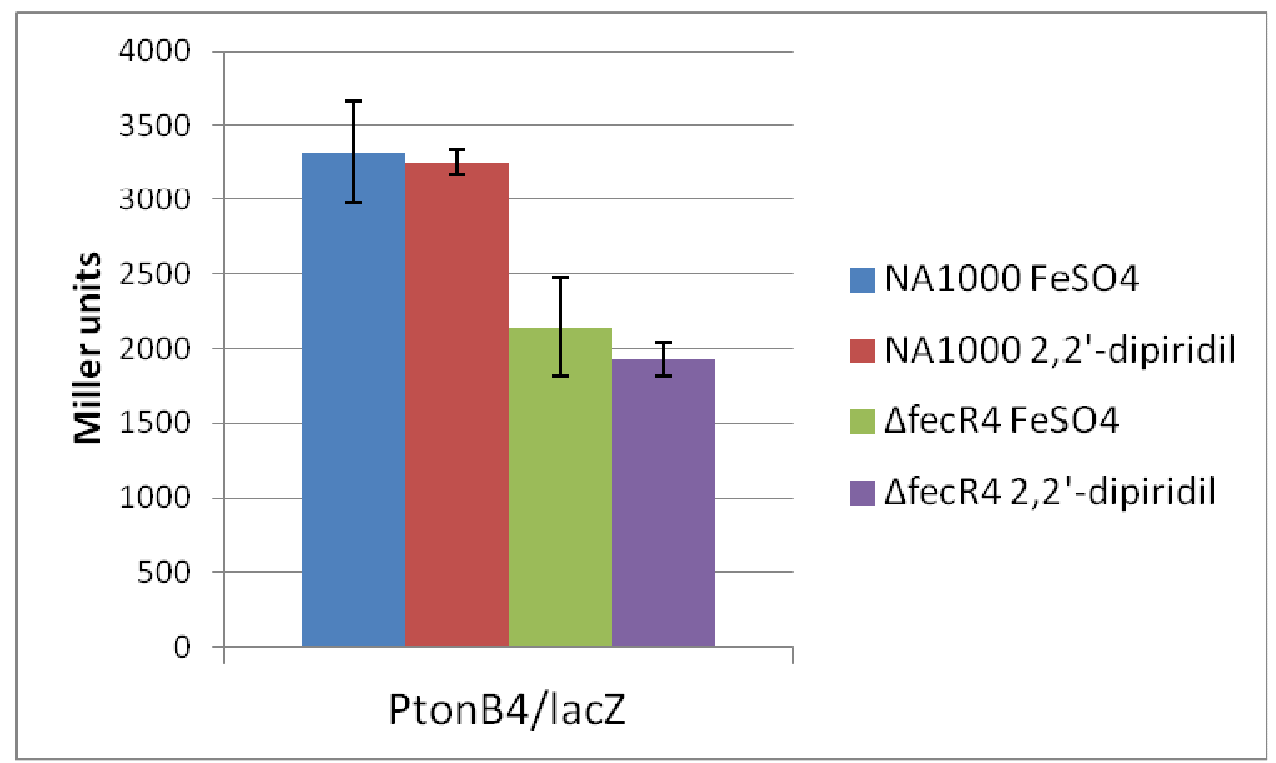

(B)

Figura 10 - Expressão de promotores PtonB em linhagens mutantes para o anti-sigma correspondente. (A) Ensaio de atividade de $\beta$-galactosidase utilizando a fusão PtonB2/lacZ na linhagem NA1000 e no mutante $\Delta f e c R 2$, em meio PYE. (B) Ensaio de atividade de $\beta$-galactosidase utilizando a fusão PtonB4/lacZ na linhagem NA1000 e no mutante $\Delta f e c R 4$, em meio PYE. Os ensaios foram realizados em meio contendo $\mathrm{FeSO}_{4}(100 \mu \mathrm{M})$ ou 2,2'-dipiridil $(100 \mu \mathrm{M})$. Os resultados são expressos em unidades Miller e representam a média de dois experimentos independentes. As barras pretas indicam o desvio padrão. 


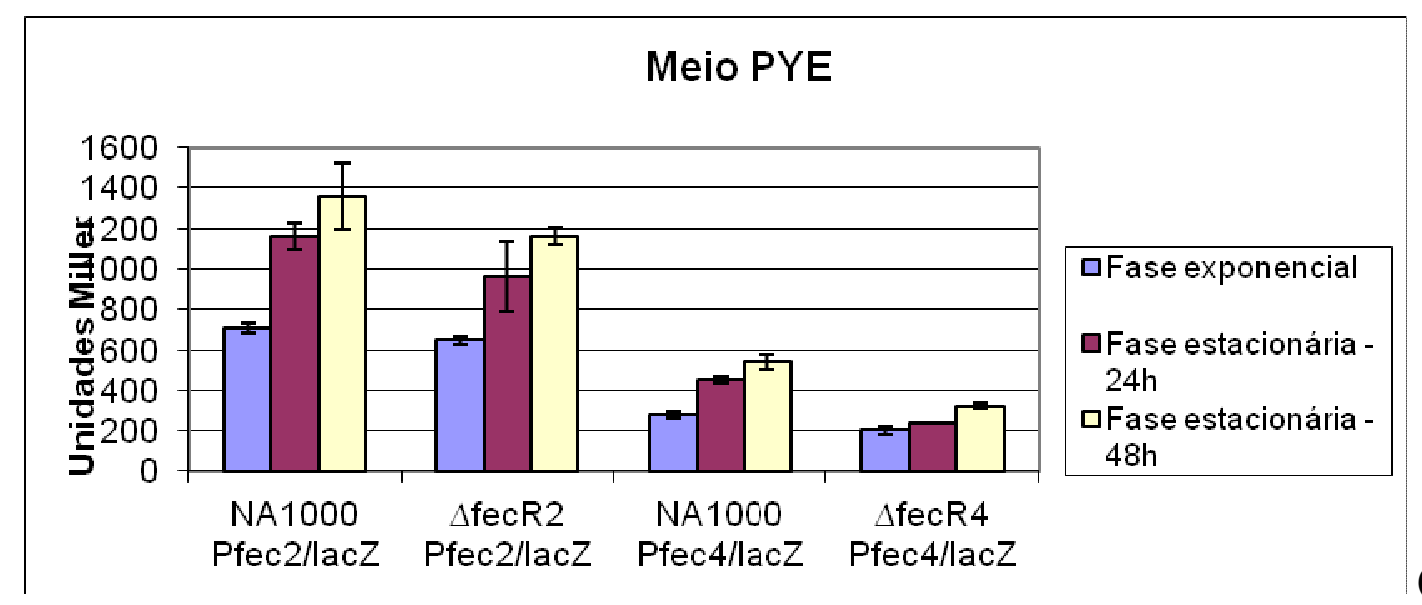

(A)

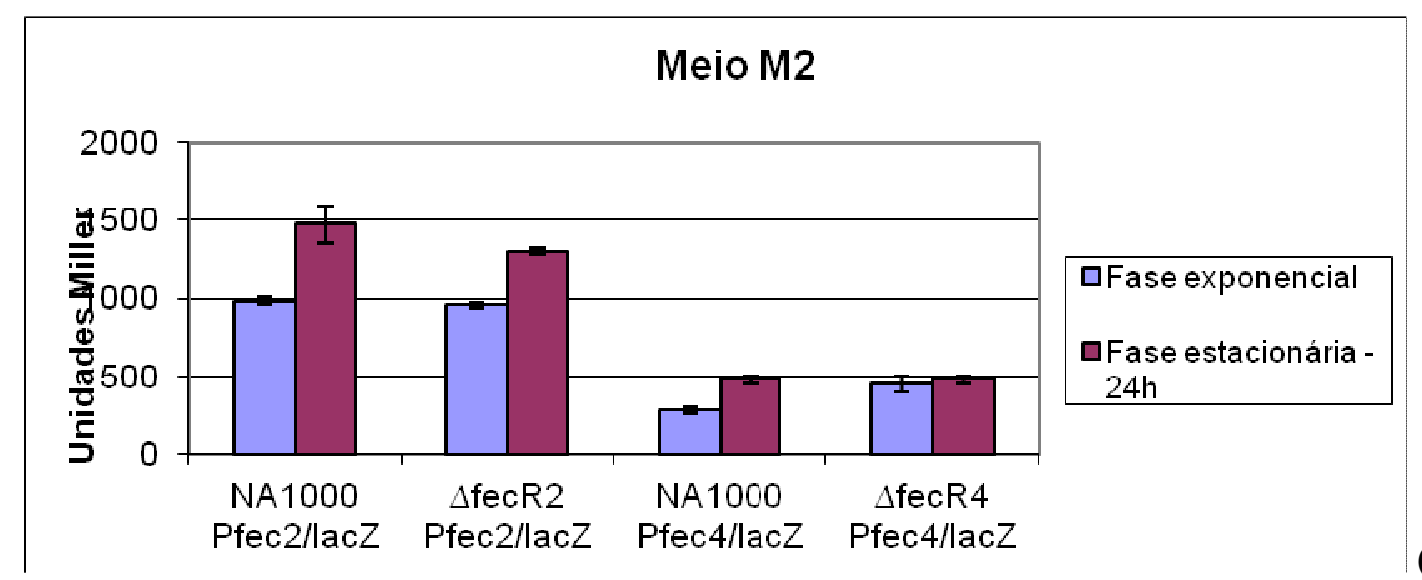

(B)

Figura 11 - Verificação da ocorrência de autorregulação dos fatores sigma FecI2 e FecI4. As construções $\mathrm{P} f e c 2 / l a c Z$ e $\mathrm{P} f e c 4 / l a c Z$ foram introduzidas nas linhagens $\Delta f e c R 2$ e $\Delta f e c R 4$, respectivamente, e sua expressão foi analisada comparativamente com a linhagem NA1000, em meio PYE (A) ou em meio M2 (B). A atividade de $\beta$-galactosidase foi medida em fase exponencial e fase estacionária. Os resultados são expressos em unidades Miller e representam a média de três replicatas técnicas. As barras pretas indicam o desvio padrão.

Para avaliar se este é o caso, as fusões transcricionais $\mathrm{P} f e c 2 / \mathrm{lacZ}$ e $\mathrm{P} f e c 4 / \mathrm{lacZ}$ foram introduzidas nas linhagens $\Delta f e c R 2$ e $\Delta f e c R 4$, respectivamente. Estas fusões contêm os promotores dos genes codificando os fatores sigma FecI2 e FecI4. As linhagens mutantes portando estas construções e também a linhagem NA1000 portando as mesmas foram incubadas em meio PYE e em meio M2, e a atividade dos promotores foi avaliada tanto em fase exponencial quanto em fase estacionária (Fig. 11). Os dois meios foram testados para descartar variações de expressão dependentes do meio de cultura. Tanto em PYE quanto em M2, a expressão observada para cada promotor na linhagem mutante é similar à observada na 
linhagem parental NA1000. Não havendo indução da expressão nestas condições, pode-se assumir que não existe autorregulação nos sistemas FEC2 e FEC4.

Isto é condizente com o descrito para fatores sigma de carência de ferro de outras espécies, como FecI de E. coli e PupI de Pseudomonas aeruginosa, que não apresentam autorregulação (BIVILLE et al., 2004). Os fatores sigma de função extracitoplasmática (ECF), à exceção dos de carência de ferro, geralmente sofrem autorregulação positiva, como forma de amplificar a resposta ao sinal (HELMANN, 2002). A ausência deste tipo de regulação em fatores sigma de carência de ferro pode ser explicada pela alta especificidade destes por poucos genes alvo, sendo desnecessária a superexpressão por autorregulação.

\subsection{Caracterização fenotípica dos mutantes}

Os sistemas FEC escolhidos para serem estudados de modo mais aprofundado neste trabalho foram os sistemas FEC2 e FEC4, de modo a se avaliar a função de um sistema mais próximo filogeneticamente ao de E. coli (FEC2) e um mais distante (FEC4).

As linhagens $\Delta f e c R 2$ e $\Delta f e c R 4$, mutantes para os antissigmas dos sistemas FEC2 e FEC4, foram avaliadas para determinar se são mais sensíveis ou resistentes à carência de ferro. As curvas de crescimento das três linhagens em meio PYE são semelhantes (Fig. 12), e todas as linhagens têm o crescimento igualmente afetado pela adição de 2,2'-dipiridil ao meio de cultura. Se os sistemas FEC de $C$. crescentus seguissem o modelo descrito para outras bactérias, a mutação em genes codificando antissigmas desses sistemas acarretaria em maior expressão de sistemas de transporte de ferro, e isso facilitaria o crescimento sob baixa disponibilidade deste metal. Entretanto, os resultados apresentados são mais uma evidência de que os sistemas FEC não aparentam estar envolvidos no metabolismo de ferro, pois o crescimento de todas as linhagens é igualmente afetado na presença do quelante de ferro. 


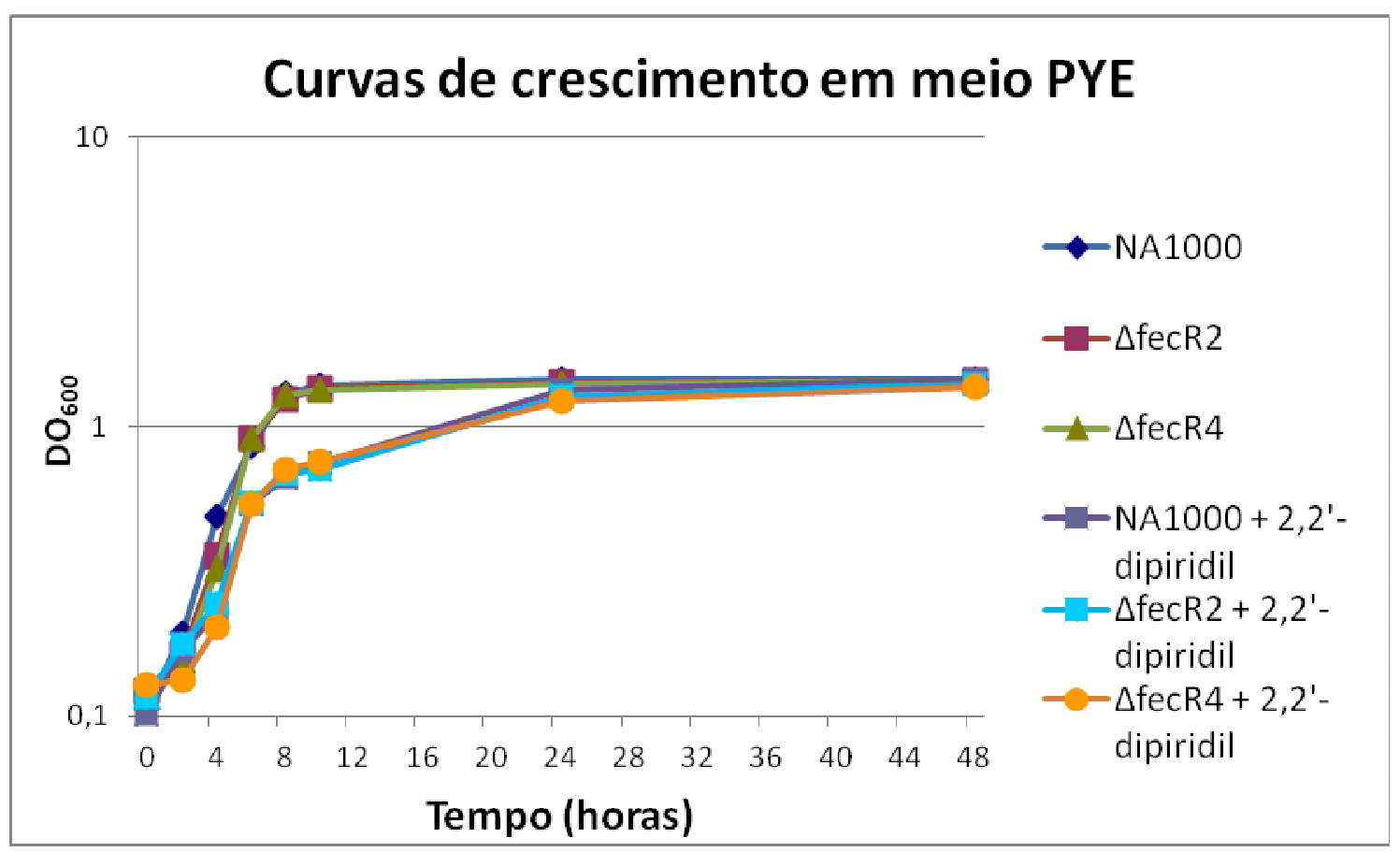

Figura 12 - Curvas de crescimento de $\Delta f e c R 2$ e $\Delta f e c R 4$ em meio PYE. Culturas de NA1000, $\Delta f e c R 2$ e $\Delta f e c R 4$ foram inoculadas em PYE, diluídas para uma densidade óptica a $600 \mathrm{~nm}\left(\mathrm{DO}_{600}\right)$ igual a 0,1 e divididas em duas alíquotas. Uma delas permaneceu como controle, e à outra foi adicionado 2,2'-dipiridil $(100 \mu \mathrm{M})$. O crescimento das culturas foi monitorado pela medição da $\mathrm{DO}_{600}$ a intervalos regulares. Os dados correspondem a uma medida representativa de três experimentos independentes.

O crescimento das linhagens também foi avaliado em meio mínimo contendo diferentes fontes de ferro. O meio mínimo M2 contém $\mathrm{FeSO}_{4}$ como única fonte de ferro (100 $\mu \mathrm{M})($ ELY, 1991), e foram preparadas variantes desse meio de cultura com substituição desta fonte de ferro por citrato férrico ou por cloreto de hemina, em igual concentração. Todas as linhagens foram capazes de crescer com as diferentes fontes de ferro, a uma taxa aproximadamente igual (Fig. 13); isto difere do descrito para E. coli, em que o mutante para o gene $f e c R$ não é capaz de crescer em meio contendo citrato férrico como única fonte de carbono (JENAL; FUCHS, 1998). Possivelmente, outros transportadores do tipo ABC presentes em $C$. crescentus são os responsáveis pelo transporte do citrato férrico, uma vez que seu genoma não possui ortólogos de $f e c B C D E$, que codificam as proteínas responsáveis pelo transporte do citrato férrico em E. coli (RODIONOV et al., 2006). No entanto, outros sistemas podem ser responsáveis pelo transporte de compostos férricos em C. crescentus, já que alguns sistemas de transporte nesta bactéria sabidamente possuem regulação pela 
disponibilidade de ferro e por Fur (DA SILVA NETO et al., 2009; DA SILVA NETO; LOURENÇO; MARQUES, 2013).

Também se analisou a sensibilidade dos mutantes a peróxido de hidrogênio. A forma reduzida de ferro $\left(\mathrm{Fe}^{2+}\right)$ reage com o peróxido de hidrogênio intracelular, originando o radical hidroxil $\left(\mathrm{OH}^{-}\right)$, com potencialidade de oxidar instantaneamente qualquer composto orgânico da célula, podendo danificar macromoléculas e componentes celulares (TOUATI, 2000). Esta reação é conhecida como reação de Fenton. Se uma linhagem apresentar maior eficiência na tomada de ferro do ambiente para o interior da célula, ela será mais sensível a peróxido de hidrogênio devido aos efeitos da reação de Fenton. A sensibilidade das linhagens a peróxido de hidrogênio ( $\mathrm{e}$, indiretamente, a possibilidade de alteração no transporte de ferro nestes mutantes) foi avaliada através de ensaio de inibição em placas, cujos resultados são mostrados na figura 14. Não houve diferenças significativas entre os diâmetros dos halos dos mutantes e os da linhagem NA1000, indicando que não houve aumento da taxa ou da velocidade da reação de Fenton intracelular e que a resposta a estresse oxidativo é semelhante entre elas.

De modo a se obter informações mais precisas sobre o tipo de regulação exercido pelos sistemas FEC2 e FEC4, foram construídas linhagens mutantes para o gene fecI4, que codifica o fator sigma FecI4, e para o gene $f e c A 2$, que codifica o receptor dependente de TonB do sistema FEC2. O crescimento das linhagens foi aferido em meio rico PYE, avaliando também se as linhagens teriam o crescimento afetado por 2,2'-dipiridil. De acordo com a figura 15, o crescimento de todas as linhagens é similar tanto na ausência quanto na presença do quelante de ferro. Em uma avaliação do crescimento em meio mínimo com diferentes fontes de ferro, todas as linhagens foram capazes de crescer com as diferentes fontes de ferro (Fig. 16), com taxas de crescimento similares, indicando que nenhuma das linhagens apresenta problemas no transporte ou na utilização destes compostos férricos. 


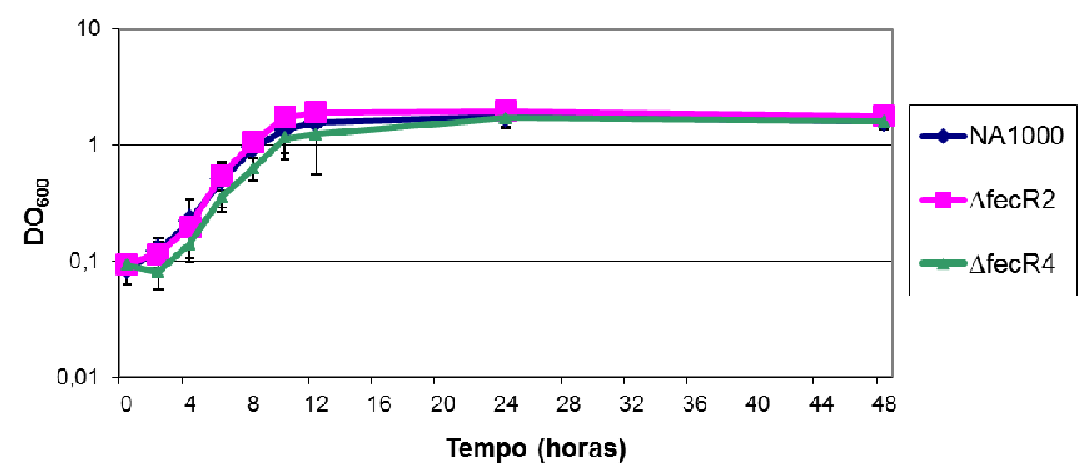

(A)

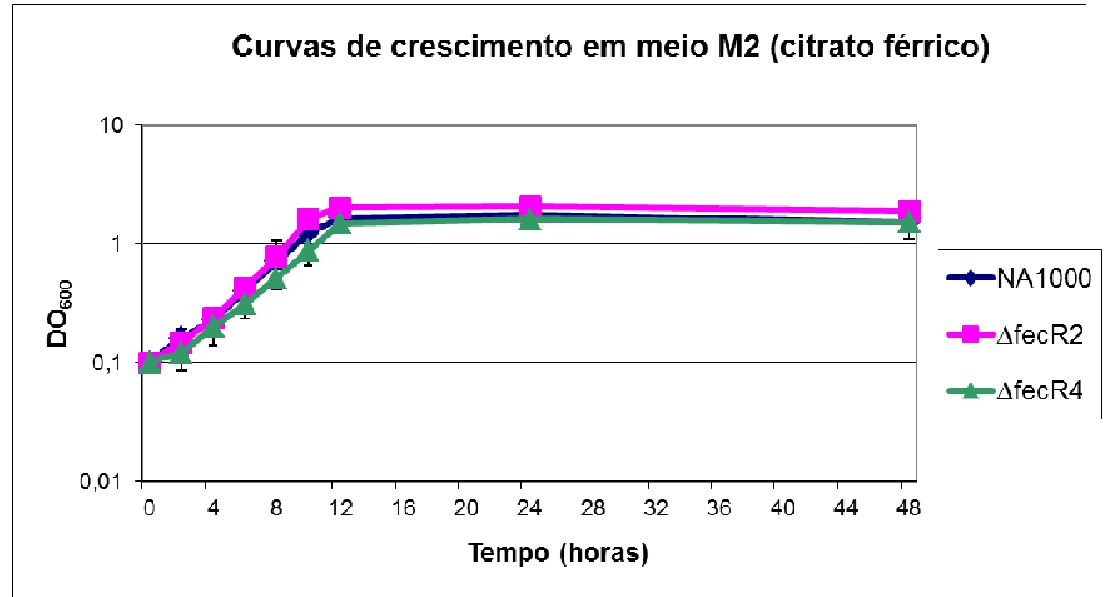

(B)

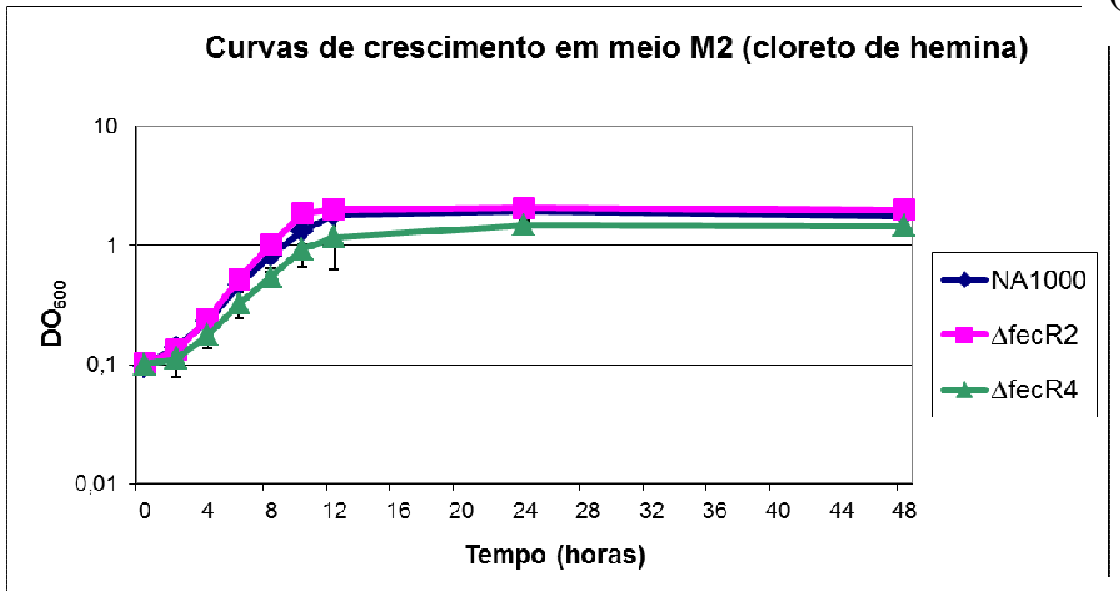

(C)

Figura 13 - Curvas de crescimento de $\Delta f e c R 2$ e $\Delta f e c R 4$ em meio mínimo M2. Culturas de NA1000, $\Delta f e c R 2$ e $\Delta f e c R 4$ foram inoculadas em M2, centrifugadas e ressuspendidas em (A) M2 (cuja fonte de ferro é $\left.\mathrm{FeSO}_{4} 100 \mu \mathrm{M}\right)$, (B) M2 contendo citrato férrico $(100 \mu \mathrm{M})$ como única fonte de ferro ou (C) M2 contendo cloreto de hemina $(100 \mu \mathrm{M})$ como única fonte de ferro. O crescimento das culturas foi monitorado pela medição da densidade óptica a $600 \mathrm{~nm}\left(\mathrm{DO}_{600}\right)$ a intervalos regulares. Os dados correspondem à média de quatro experimentos independentes. As barras pretas indicam o desvio padrão. 


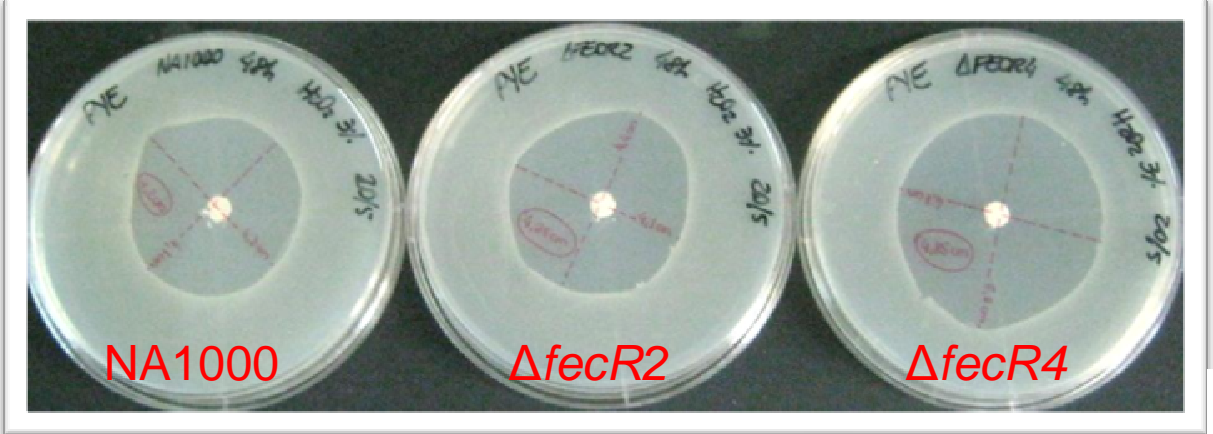

(A)

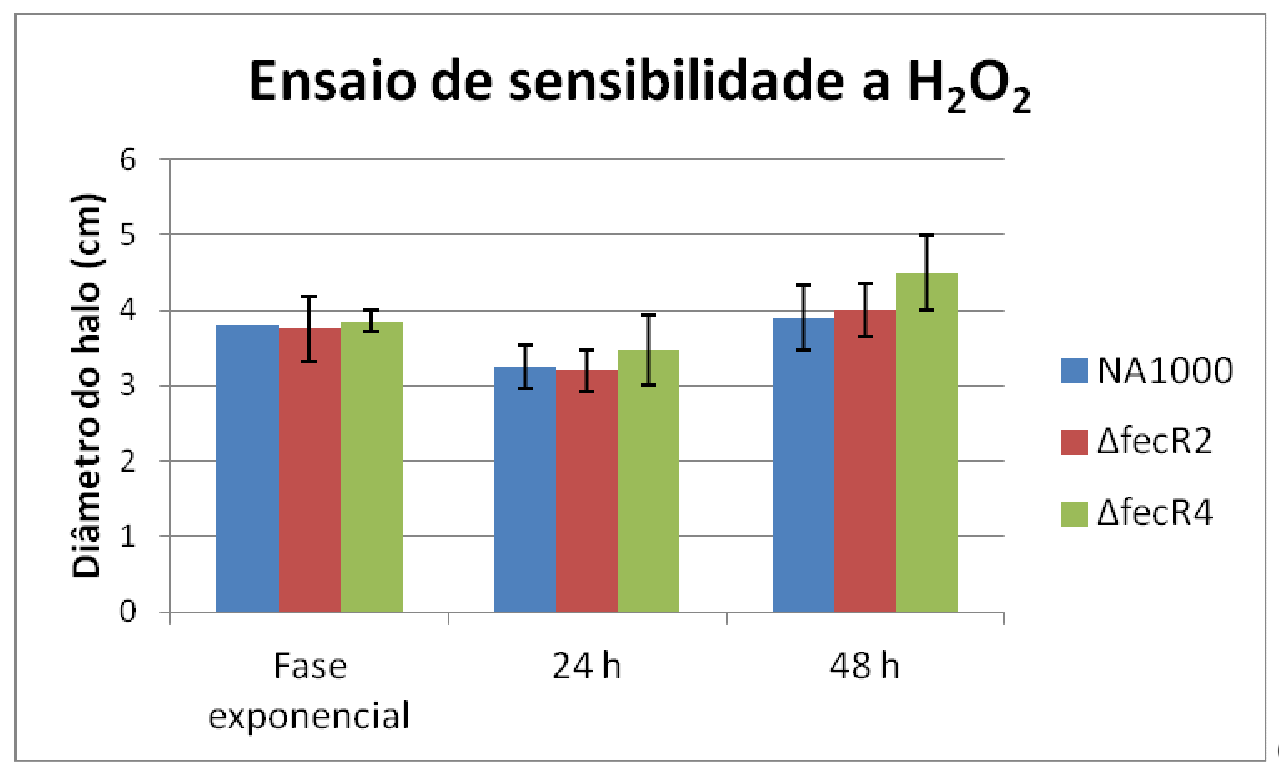

(B)

Figura 14 - Ensaio de sensibilidade a peróxido de hidrogênio. As culturas foram inoculadas em PYE e semeadas em placas de PYE ágar. Um disco de papel de filtro contendo $10 \mu l$ de uma solução $3 \%$ de peróxido de hidrogênio foi aplicado no centro de cada placa. (A) Placas com culturas em fase estacionária (48 horas). (B) Medidas do diâmetro dos halos de inibição. Os valores representam a média de dois experimentos. As barras pretas indicam o desvio padrão. 
Média das curvas de crescimento (em PYE)

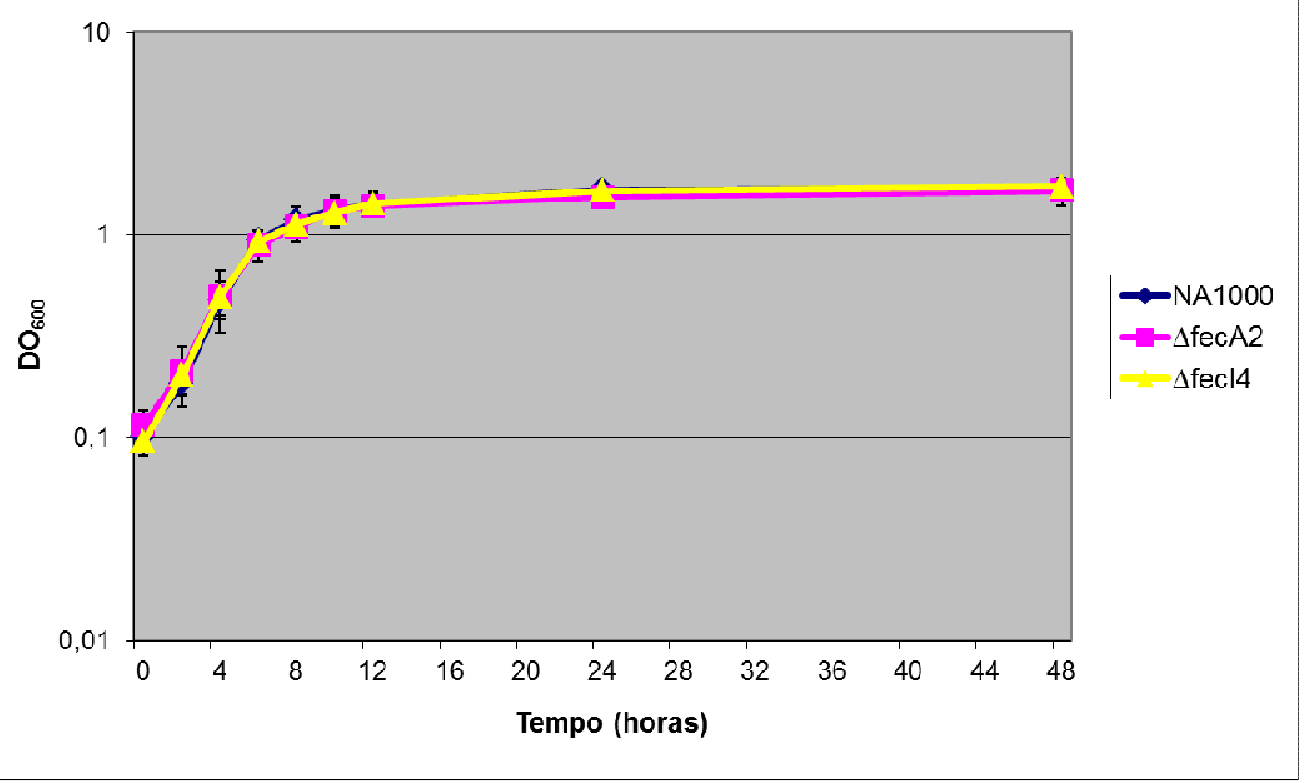

(A)

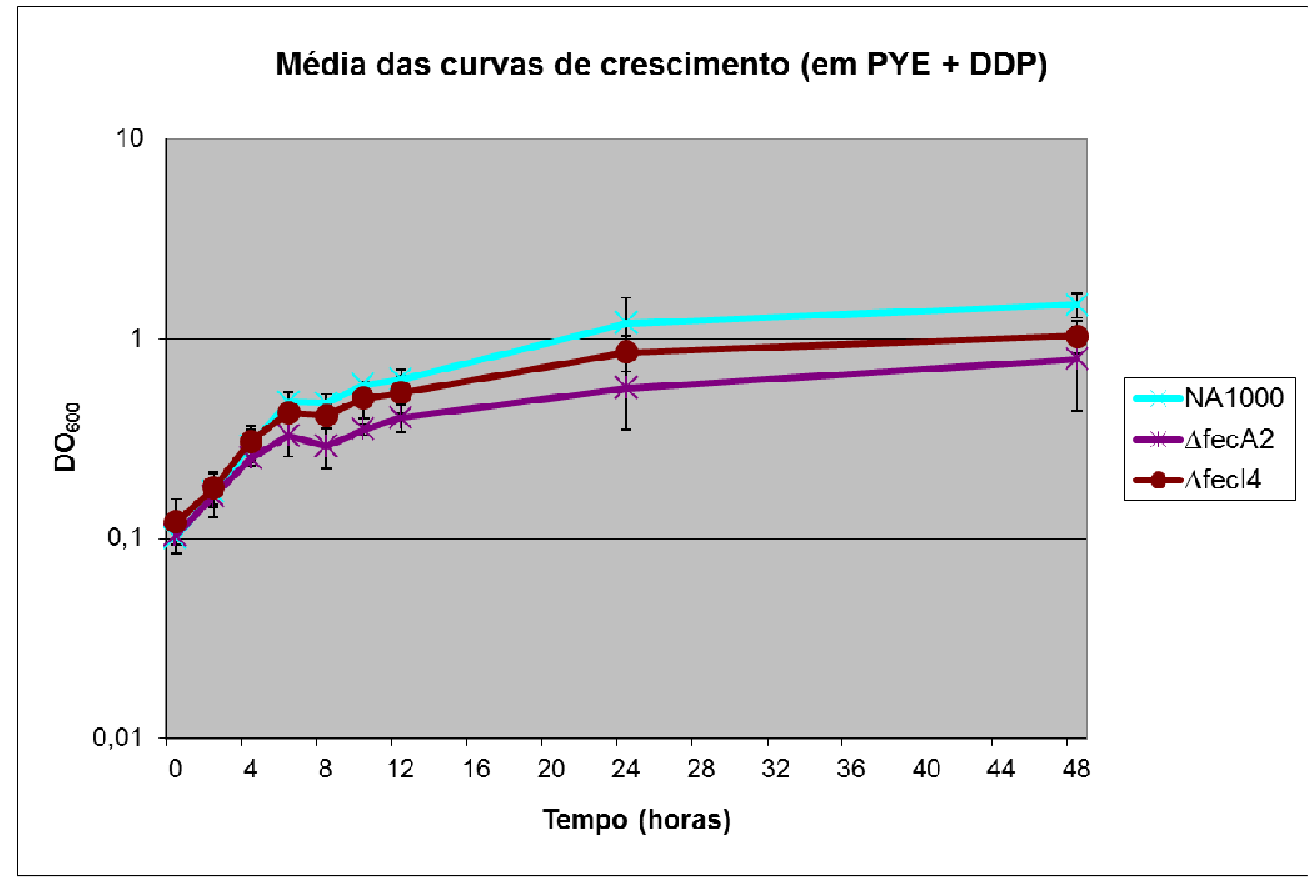

(B)

Figura 15 - Curvas de crescimento dos mutantes $\Delta f e c A 2$ e $\Delta f e c I 4$ em meio PYE. Culturas de NA1000, $\Delta f e c A 2$ e $\Delta f e c I 4$ foram inoculadas em PYE, diluídas para uma densidade óptica a $600 \mathrm{~nm}$ $\left(\mathrm{DO}_{600}\right)$ igual a 0,1 e divididas em duas alíquotas. Uma delas permaneceu como controle $(\mathrm{A})$, e à outra foi adicionado 2,2'-dipiridil (DDP, $100 \mu \mathrm{M})$ (B). O crescimento das culturas foi monitorado pela medição da $\mathrm{DO}_{600}$ a intervalos regulares. Os dados correspondem à média de dois experimentos independentes. As barras pretas indicam o desvio padrão. 


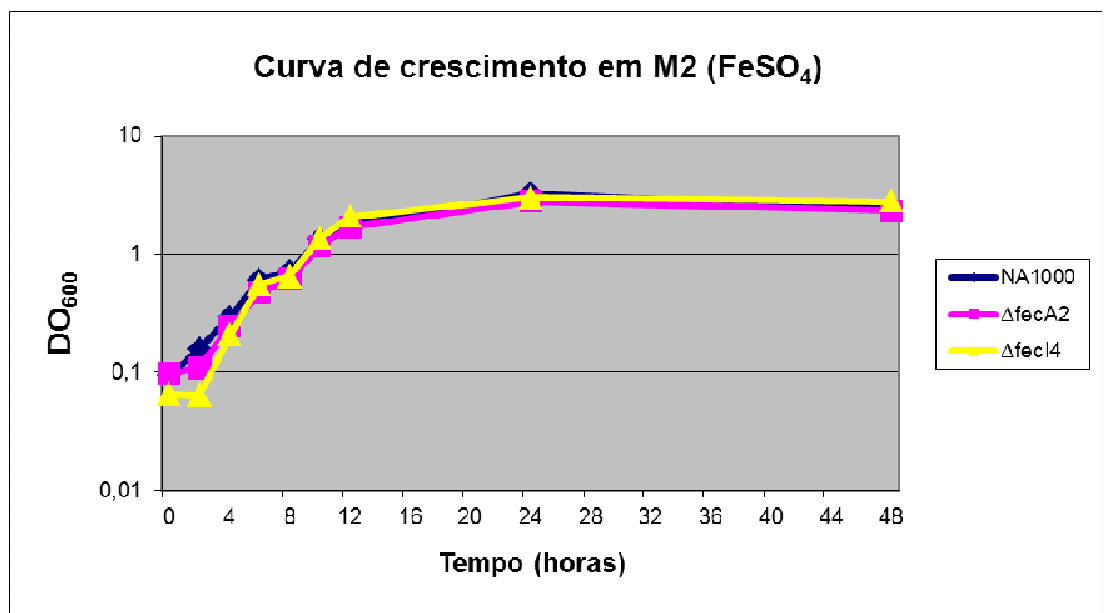

(A)

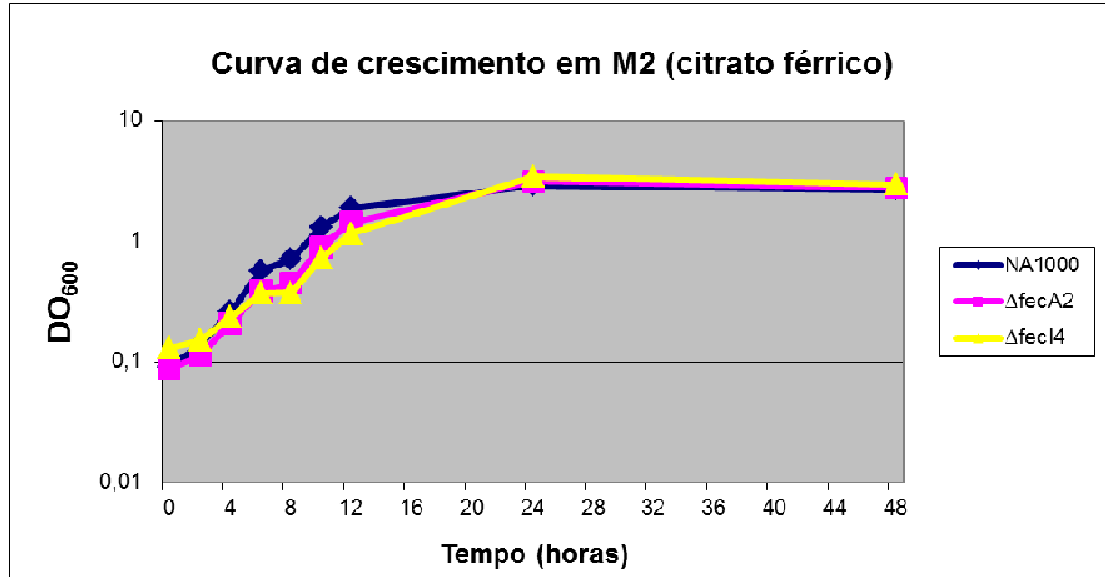

(B)

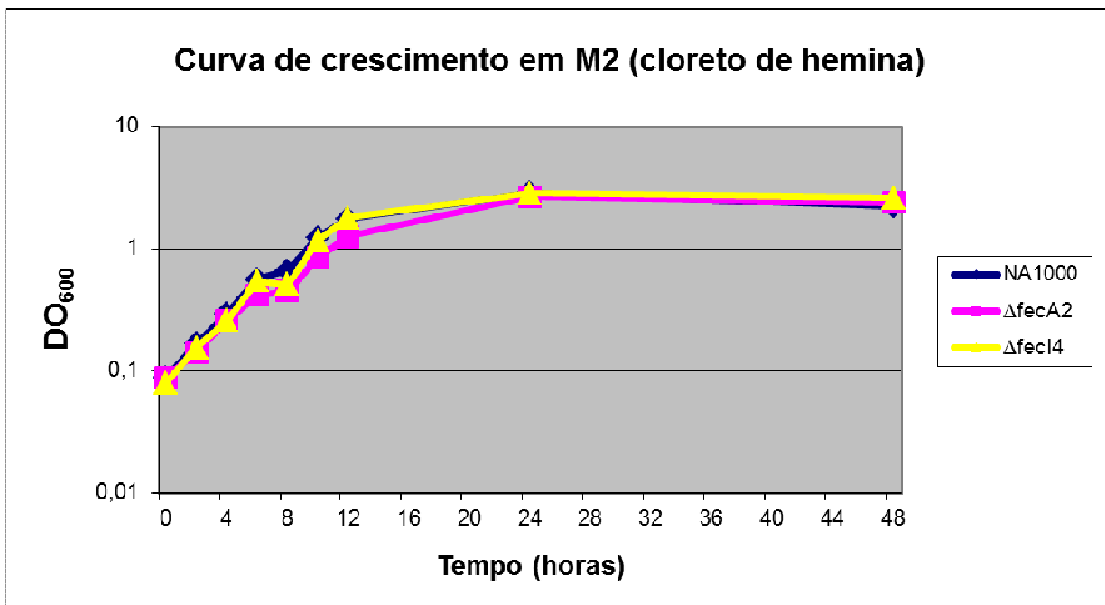

(C)

Figura 16 - Curvas de crescimento de $\Delta f e c A 2$ e $\Delta f e c I 4$ em meio mínimo M2. Culturas de NA1000, $\Delta f e c A 2$ e $\Delta f e c I 4$ foram inoculadas em M2, centrifugadas e ressuspendidas em (A) M2 (cuja fonte de ferro é $\left.\mathrm{FeSO}_{4} 100 \mu \mathrm{M}\right)$, (B) $\mathrm{M} 2$ contendo citrato férrico $(100 \mu \mathrm{M})$ como única fonte de ferro ou (C) M2 contendo cloreto de hemina $(100 \mu \mathrm{M})$ como única fonte de ferro. O crescimento das culturas foi monitorado pela medição da $\mathrm{DO}_{600}$ a intervalos regulares. 
O perfil de crescimento da linhagem parental NA1000 foi analisado na presença de diferentes concentrações de quelantes de ferro. A figura 17A mostra que o crescimento foi afetado pela presença dos quelantes na cultura, já que a densidade óptica $\left(\mathrm{DO}_{600}\right)$ máxima obtida nestas condições foi de aproximadamente 0,4 no ponto de 4 horas, enquanto que na ausência de quelantes a $\mathrm{DO}_{600}$ atingiu acima de 0,5, com esta diferença se tornando mais evidente no ponto de 18 horas. A seguir, foi averiguado se a adição do sideróforo ferricromo às culturas restauraria o crescimento. No ponto de 18 horas, ferricromo foi adicionado às culturas e o crescimento foi monitorado. Como mostrado na figura 17B, o crescimento foi retomado em todas as condições, exceto em NB com $200 \mu \mathrm{M}$ de 2,2'-dipiridil; provavelmente, a concentração do quelante foi muito alta para permitir o crescimento, mesmo após a adição do sideróforo.

Estas curvas de crescimento também revelaram que apo-enterobactina é um quelante de ferro eficiente para $C$. crescentus, uma vez que o crescimento é bastante prejudicado pela presença desta molécula (Fig. 17B). Este efeito se mostrou ser causado realmente por deficiência de ferro, uma vez que a adição de ferricromo restaurou o crescimento, refutando a hipótese de que os efeitos deste ensaio sobre o crescimento (ou mesmo os efeitos dos ensaios de utilização de sideróforos em placas) fossem resultado de uma potencial toxicidade ou efeito secundário causado pela apo-enterobactina.

Para se avaliar a utilização de sideróforos por C. crescentus, realizaram-se testes em que as células são semeadas em meio contendo quelante de ferro e um filtro de papel contendo um sideróforo é aplicado na superfície da placa. Quando determinado sideróforo é utilizado, é possível observar a formação de um halo de crescimento ao redor do filtro de papel. Estes ensaios foram possíveis com a utilização de uma biblioteca de sideróforos disponibilizada pelos professores Dr. Phillip Klebba e Dra. Salete Newton, da Kansas State University, nos Estados Unidos da América, durante um período de Doutorado Sanduíche.

Testes preliminares foram realizados em placas de seis poços, em menor escala, para padronização das condições do experimento com relação à concentração do quelante de ferro e dos sideróforos. O quelante utilizado nestes testes preliminares foi 2,2'-dipiridil, a uma concentração de $200 \mu \mathrm{M}$. A figura 18 mostra um exemplo do resultado deste experimento, revelando que $C$. crescentus utiliza ferricromo como fonte de ferro, mas não enterobactina. Diferentes meios foram testados (PYE, M2 ou NB), e o meio escolhido para realização dos experimentos foi $\mathrm{NB}$, por fornecer resultados mais visíveis e reprodutíveis (dados não mostrados). 


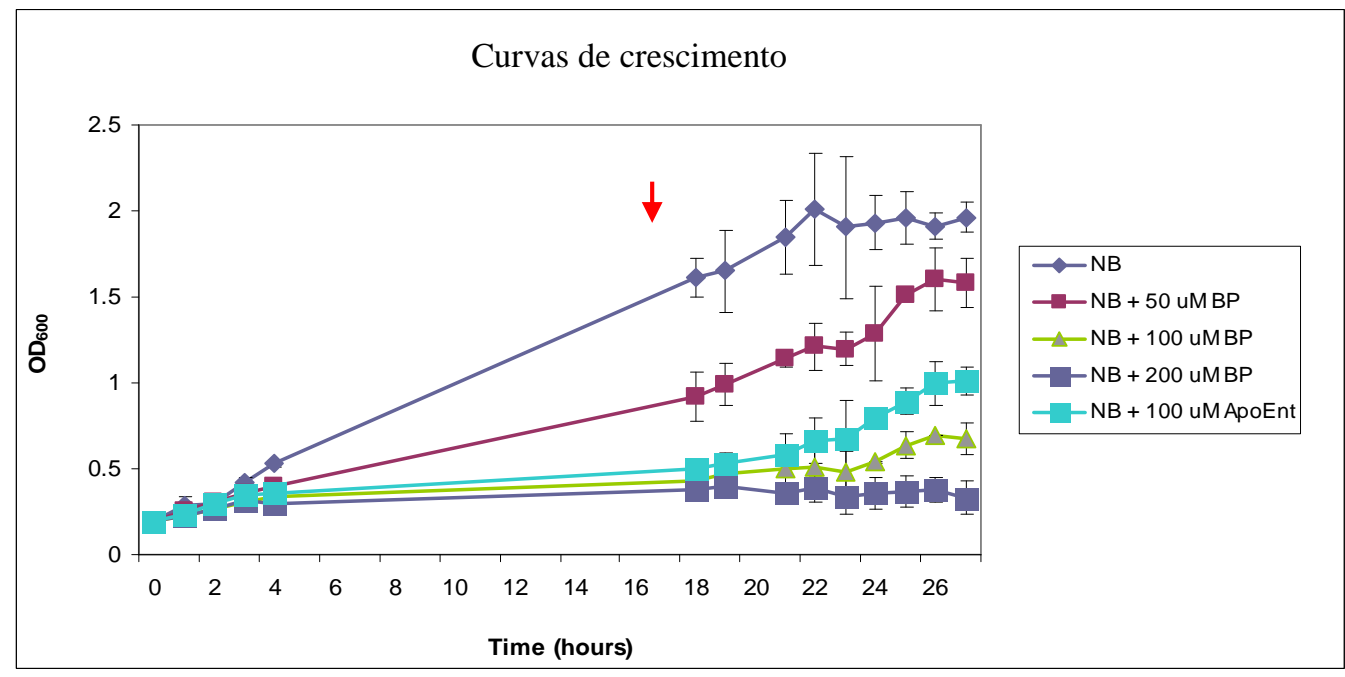

(A)

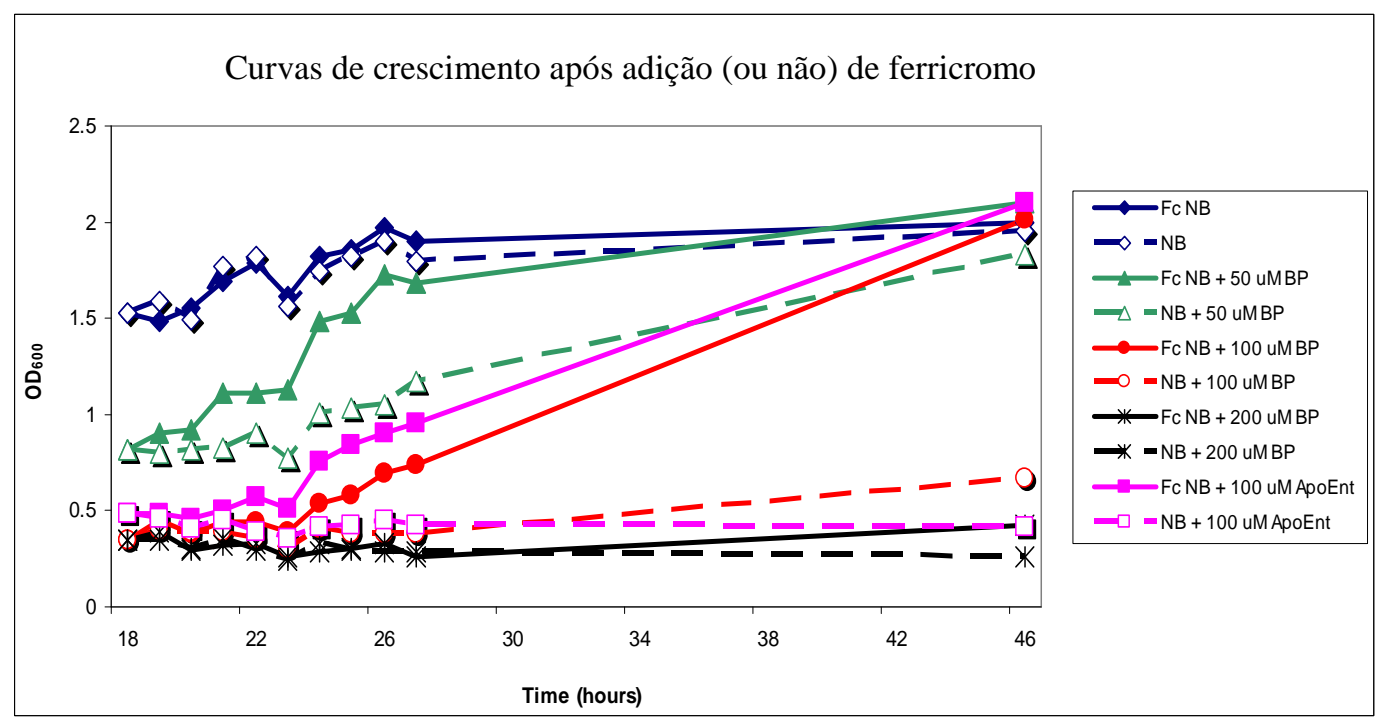

(B)

Figura 17 - Curvas de crescimento de NA1000 na presença de quelantes de ferro ou ferricromo. (A) Efeito dos quelantes de ferro no crescimento inicial e retomada do crescimento após adição de ferricromo. BP, 2,2'-dipiridil; ApoEnt, apo-enterobactina. Ferricromo foi adicionado a uma concentração final de $10 \mu \mathrm{M}$, no ponto indicado pela seta. Os resultados são expressos como a média de dois experimentos. As barras pretas indicam o desvio padrão. (B) Comparação entre as curvas de crescimento após adição de $10 \mu \mathrm{M}$ de ferricromo (indicado por Fc, linhas cheias) ou sem a adição (linhas tracejadas). Curva representativa de um experimento. 

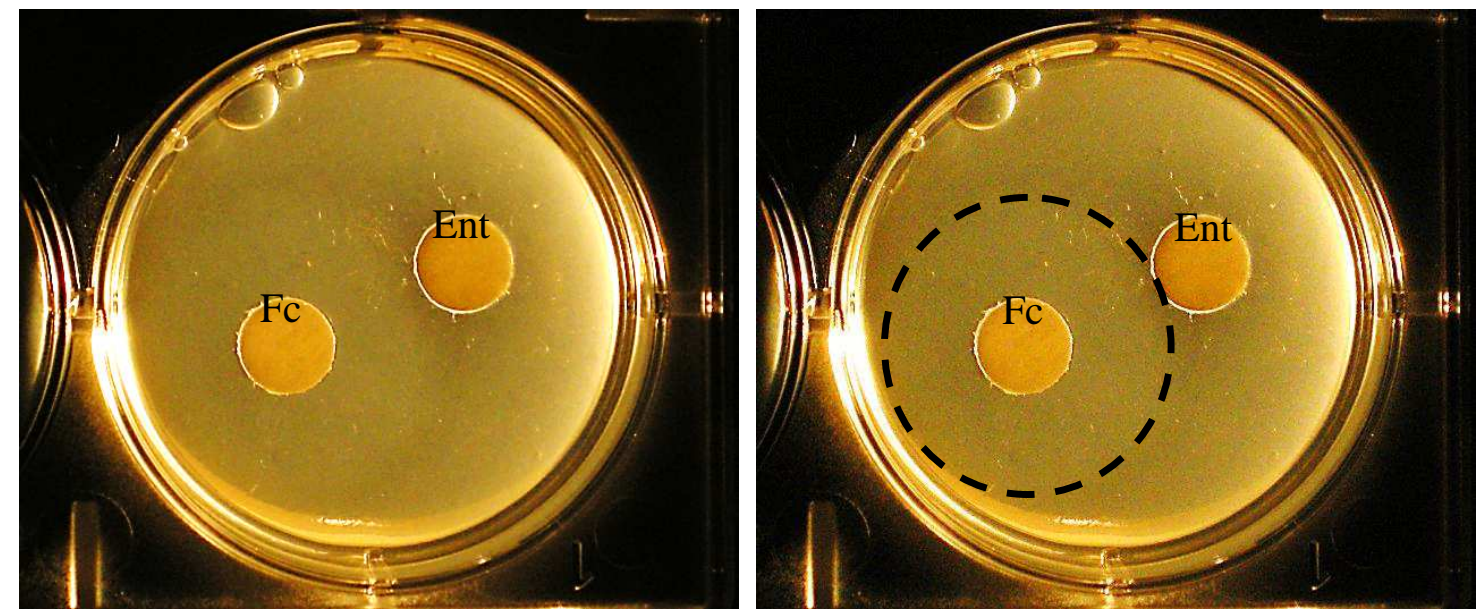

Figura 18 - Teste de utilização de sideróforos utilizando 2,2'-dipiridil como quelante de ferro. À esquerda, detalhe do poço de uma placa de 6 poços contendo células de NA1000 em meio NB com $200 \mu \mathrm{M}$ de 2,2'-dipiridil como quelante de ferro e ferricromo ( $\mathrm{Fc}$ ) e enterobactina (Ent) como fontes de ferro $(2.5 \mu \mathrm{l}$ de soluções $100 \mu \mathrm{M})$. À direita, a mesma imagem mostrando a posição do halo de crescimento ao redor do ferricromo.
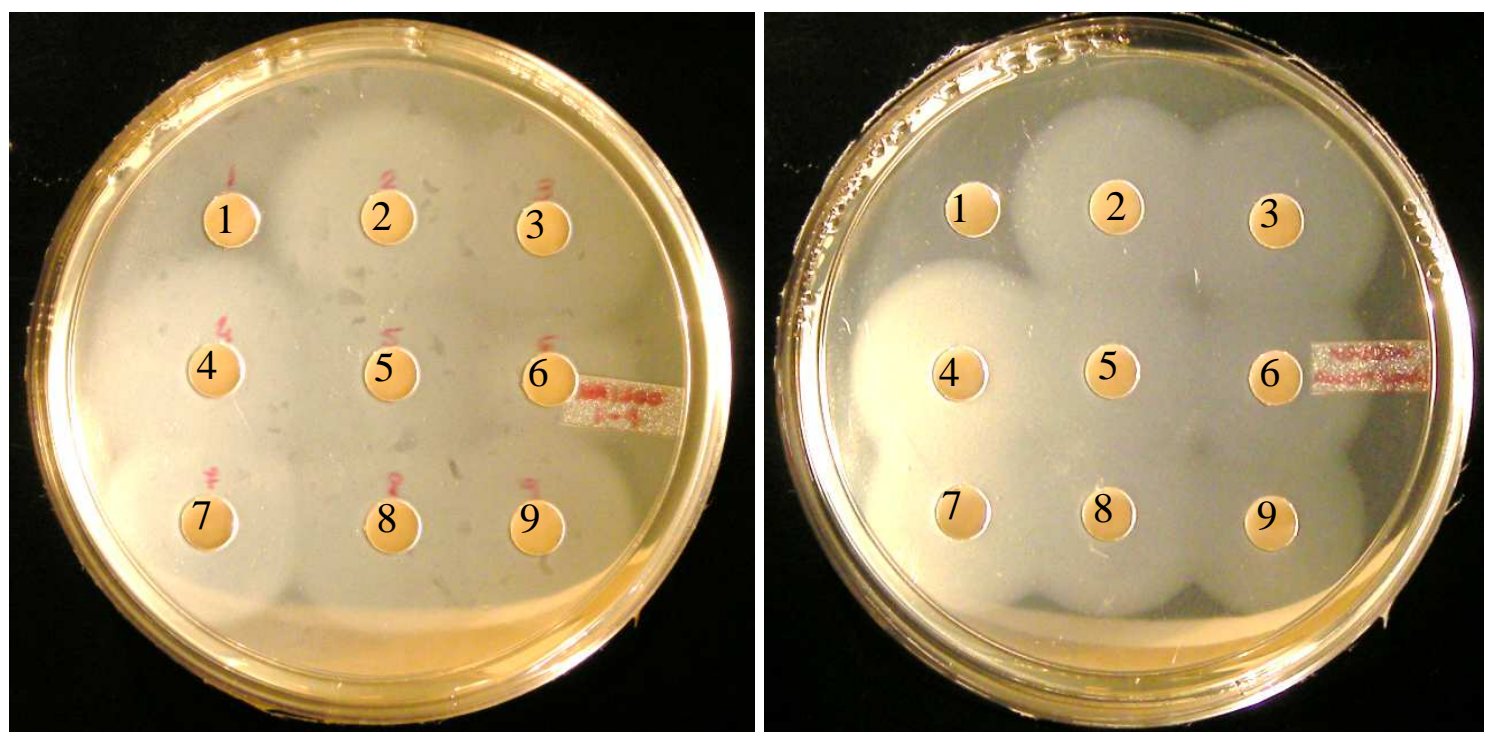

Figura 19 - Comparação entre testes de utilização de sideróforos com diferentes quelantes de ferro. Os experimentos foram realizados com células de NA1000 em meio NB. À esquerda, ensaio utilizando 2,2'-dipiridil (200 $\mu \mathrm{M})$. À direita, ensaio utilizando apo-enterobactina $(100 \mu \mathrm{M})$. A legenda dos sideróforos encontra-se na Tabela 4. 
Como C. crescentus não utilizou enterobactina (conforme o observado na figura 18), apo-enterobactina (isto é, enterobactina sem ferro associado) foi utilizado como quelante de ferro nestes ensaios. Uma comparação entre experimentos utilizando 2,2'-dipiridil e apoenterobactina é mostrada na figura 19. Como se pode observar, os halos são mais conspícuos e definidos quando apo-enterobactina é utilizada. Portanto, este foi o quelante de ferro escolhido para realizar os experimentos. Uma razão pela qual este parece ser um quelante melhor para os ensaios é que apo-enterobactina é estritamente específica para átomos de ferro, enquanto 2,2'-dipiridil pode ligar outros íons divalentes além do ferro. Como C. crescentus necessita de cálcio para seu crescimento, pode-se argumentar que estes íons poderiam estar sendo sujeitos à ação do 2,2'-dipiridil, interferindo na aquisição de resultados ótimos. No entanto, o perfil de crescimento de C. crescentus obtido com ambos os quelantes foi o mesmo com todos os sideróforos testados (dados não mostrados).

O fato de $C$. crescentus NA1000 não utilizar enterobactina como sideróforo é digno de nota. Várias outras bactérias Gram-negativas foram descritas como capazes de transportar enterobactina, como espécies dos gêneros Shigella, Salmonella, Klebsiella, Citrobacter, Serratia, Enterobacter, Edwardsiella, Hafnia, Yersinia, Providencia, Morganella, Proteus, Haemophilus e Neisseria, bem como a própria E. coli (RUTZ et al., 1991). No referido estudo, $94 \%$ das bactérias testadas transportaram enterobactina férrica. De fato, C. crescentus provavelmente está exposta à enterobactina férrica em seu habitat natural, uma vez que solos e superfícies aquáticas são também habitats de espécies dos gêneros Klebsiella, Enterobacter e Erwinia, produtoras de enterobactina (HIDER; KONG, 2010). Assim, é curioso que $C$. crescentus NA1000 não seja capaz de tirar vantagem da presença de enterobactina.

A tabela 4 lista todos os sideróforos testados com C. crescentus. Os ensaios revelaram que $C$. crescentus NA1000 é capaz de utilizar uma ampla gama de sideróforos do tipo hidroxamato (Fig. 20 e Tabela 4). Uma observação interessante é a de que C. crescentus não parece utilizar sideróforos de outras categorias, dado que nem catecóis nem sideróforos de função mista promoveram o crescimento (Fig. 20 e Tabela 4). 
Tabela 4. Sideróforos testados.

\begin{tabular}{|c|c|c|c|}
\hline Número nas placas & Sideróforo & Categoria & Crescimento \\
\hline 1 & Desferral & Hidroxamato & Não \\
\hline 2 & Aspercromo B1 & Hidroxamato & Sim \\
\hline 3 & Aspercromo B2 & Hidroxamato & Sim \\
\hline 4 & Aspercromo C & Hidroxamato & Sim \\
\hline 5 & Aspercromo D1 & Hidroxamato & Sim \\
\hline 6 & Ferricromo A & Hidroxamato & Sim \\
\hline 7 & Ferricromo C & Hidroxamato & Sim \\
\hline 8 & Ferricrisina & Hidroxamato & Sim \\
\hline 9 & Ferricrocina & Hidroxamato & Sim \\
\hline 10 & Ferrirrodina & Hidroxamato & Sim \\
\hline 11 & Ferrirrubina & Hidroxamato & Sim \\
\hline 12 & Malonicromo & Hidroxamato & Sim \\
\hline 13 & Ferricromo tetraglicina & Hidroxamato & Sim \\
\hline 14 & Coprogênio & Hidroxamato & Não \\
\hline 15 & Ácido dimerum & Hidroxamato & Não \\
\hline 16 & Ácido rodotorúlico & Hidroxamato & Não \\
\hline 17 & Fusarinina & Hidroxamato & Não \\
\hline 18 & Triacetilfusarinina & Hidroxamato & Não \\
\hline 19 & Ferricromo & Hidroxamato & Sim \\
\hline 20 & $\mathrm{FeSO}_{4}$ & (Usado para testar o crescimento) & Não \\
\hline 21 & Nocardamina & Hidroxamato & Não \\
\hline 22 & Tioformina & Hidroxamato & Não \\
\hline 23 & Água destilada & (Controle negativo) & Não \\
\hline 24 & Ferrioxamina B & Hidroxamato & Não \\
\hline 25 & Aerobactina & $\begin{array}{l}\text { Mista (Hidroxamato/ } \alpha- \\
\text { hidroxicarboxilato) }\end{array}$ & Não \\
\hline 26 & Agrobactina & Catecol & Não \\
\hline 27 & Corinebactina & Catecol & Não \\
\hline 28 & Enterobactina & Catecol & Não \\
\hline 29 & Vibriobactina & Catecol & Não \\
\hline 30 & Albomicina & Derivado de antibiótico & Não \\
\hline 31 & Micobactina & Mista (Hidroxamato/fenolato) & Não \\
\hline 32 & Pseudobactina & Mista (Hidroxamato/fenolato) & Não \\
\hline 33 & Esquizocineno & $\begin{array}{c}\text { Mista (Hidroxamato/ } \alpha- \\
\text { hidroxicarboxilato) }\end{array}$ & Não \\
\hline
\end{tabular}



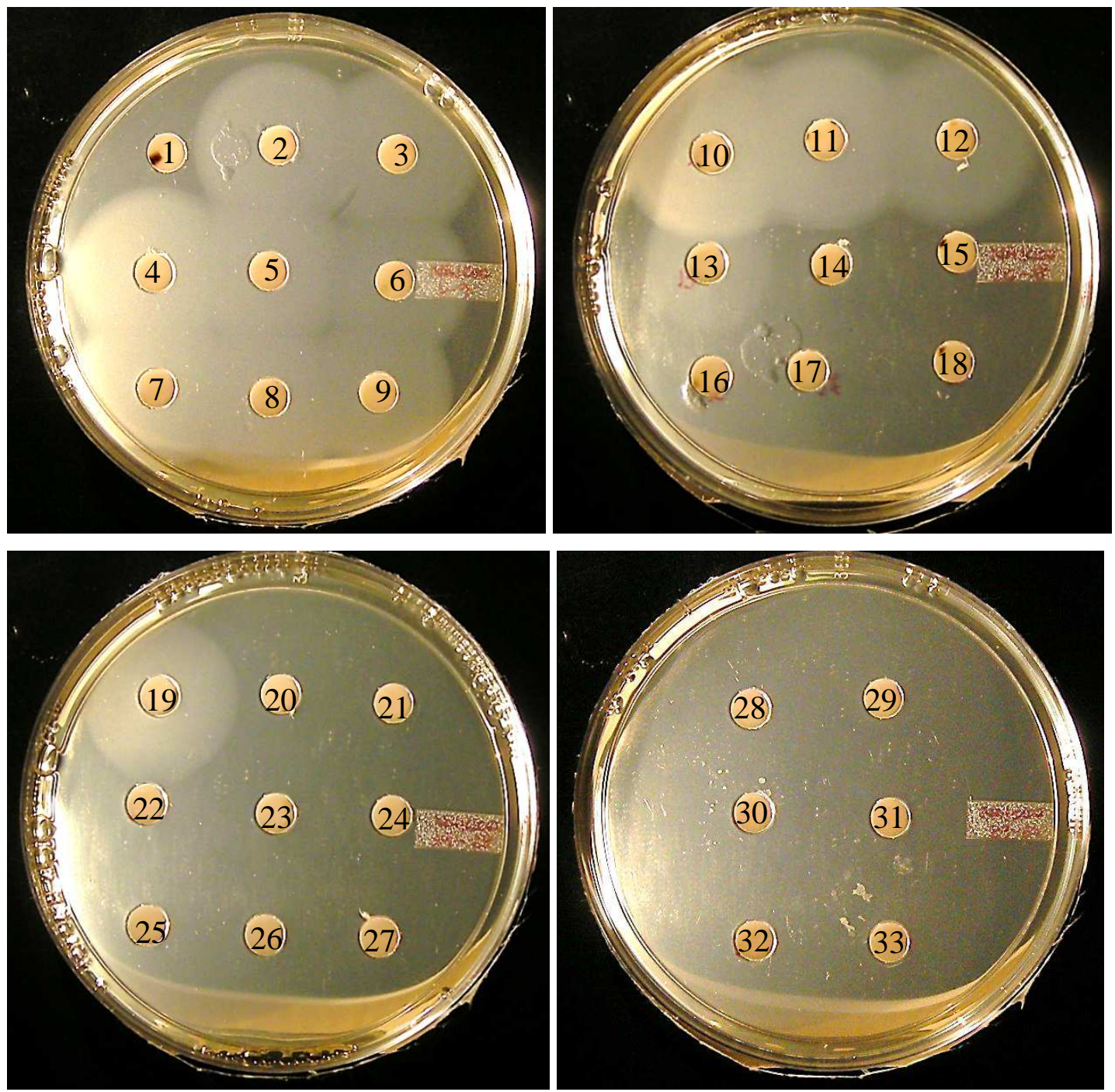

Figura 20 - Utilização de sideróforos por C. crescentus NA1000. A legenda dos sideróforos encontra-se na Tabela 4.

Estes resultados são discrepantes daqueles obtidos por Neugebauer et al. (2005), em que C. crescentus é descrita como capaz de utilizar ácido rodotorúlico e desferral e incapaz de crescer em ferricromo, ferricrocina e ferricromo A, embora alguns resultados sejam similares, como a incapacidade de esquizocineno e coprogênio de promover o crescimento. Estas diferenças podem ser atribuídas às condições dos experimentos, já que a concentração de sideróforos e a natureza e concentração dos quelantes de ferro foram diferentes de nossos experimentos. Além disso, a linhagem de C. crescentus usada por Neugebauer et al. (2005) foi diferente da nossa, o que também pode explicar as diferenças entre os dois trabalhos.

O perfil de crescimento das linhagens mutantes em diferentes sideróforos foi similar àquele observado para NA1000 (Fig. 21-24). A tabela 5 mostra as medidas dos diâmetros de 
halos para cada linhagem. Os resultados relativos às linhagens $\Delta f e c A 2$ e $\Delta f e c R 2$ são oriundos de um único experimento, devido à impossibilidade de repetir o experimento realizado durante o estágio Sanduíche, com a proximidade do prazo de retorno ao Brasil.
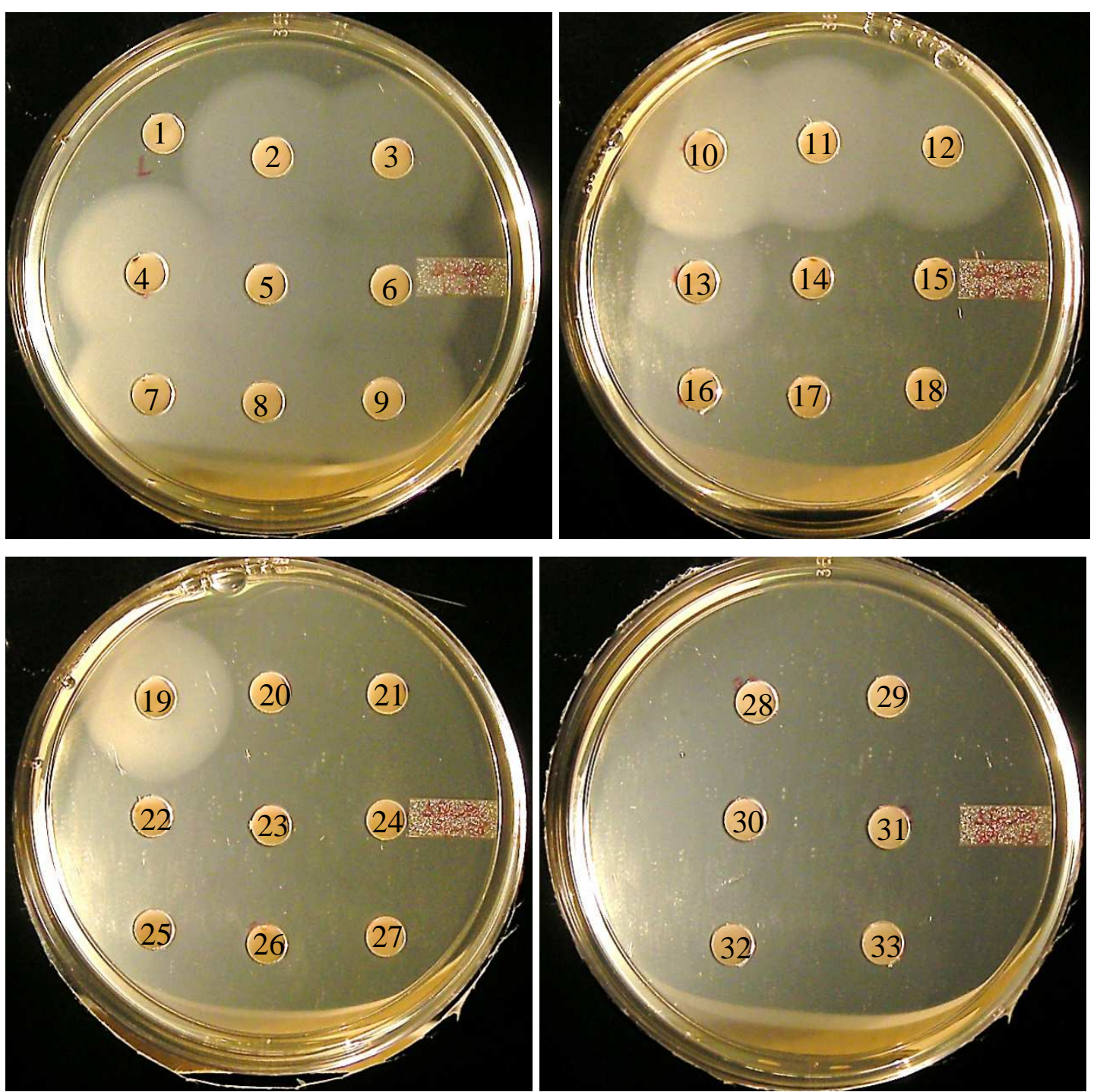

Figura 21 - Utilização de sideróforos por $C$. crescentus $\Delta$ fecA2. A legenda dos sideróforos encontra-se na Tabela 4. 

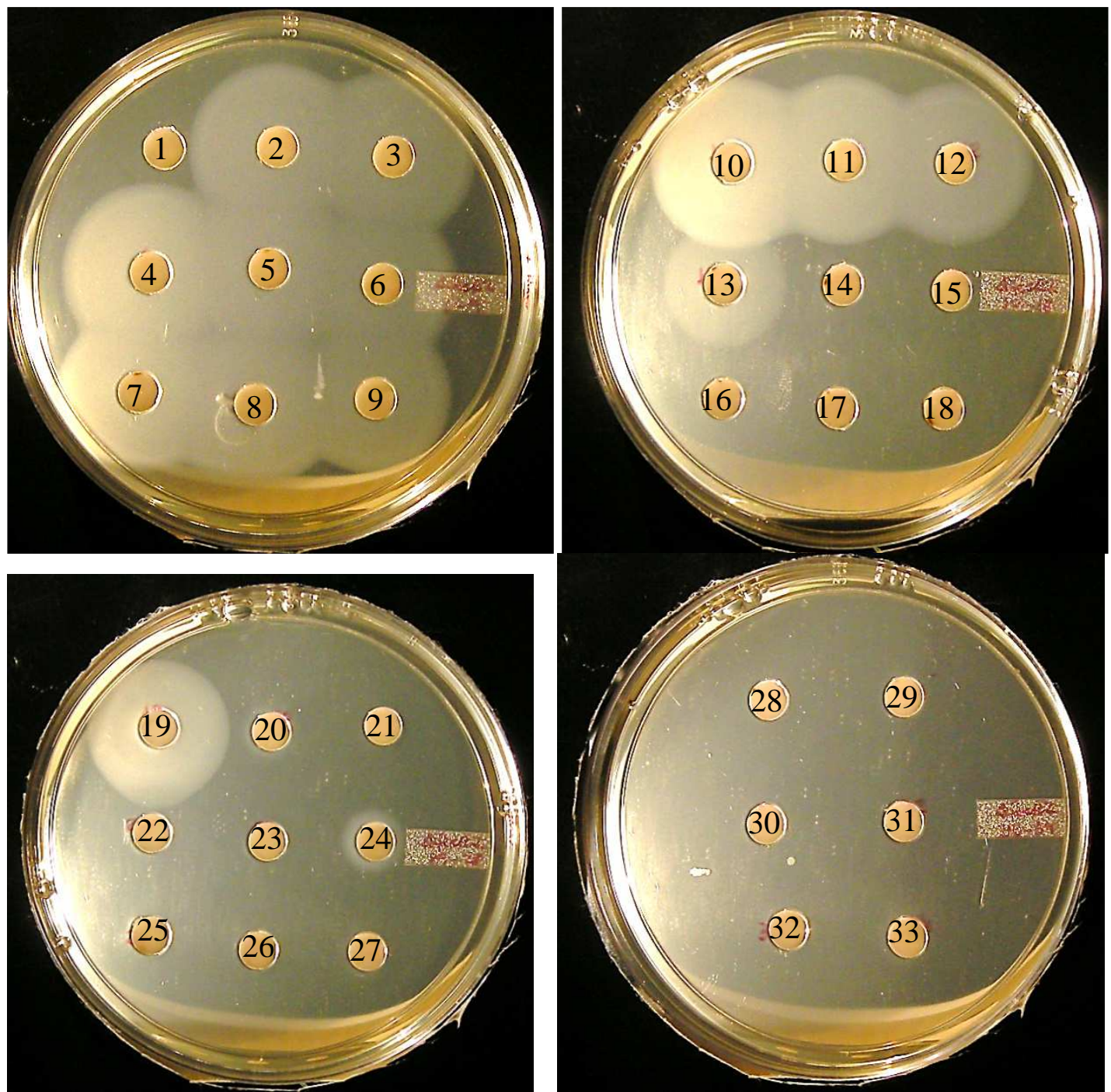

Figura 22- Utilização de sideróforos por $C$. crescentus $\Delta f e c R 2$. A legenda dos sideróforos encontrase na Tabela 4. 

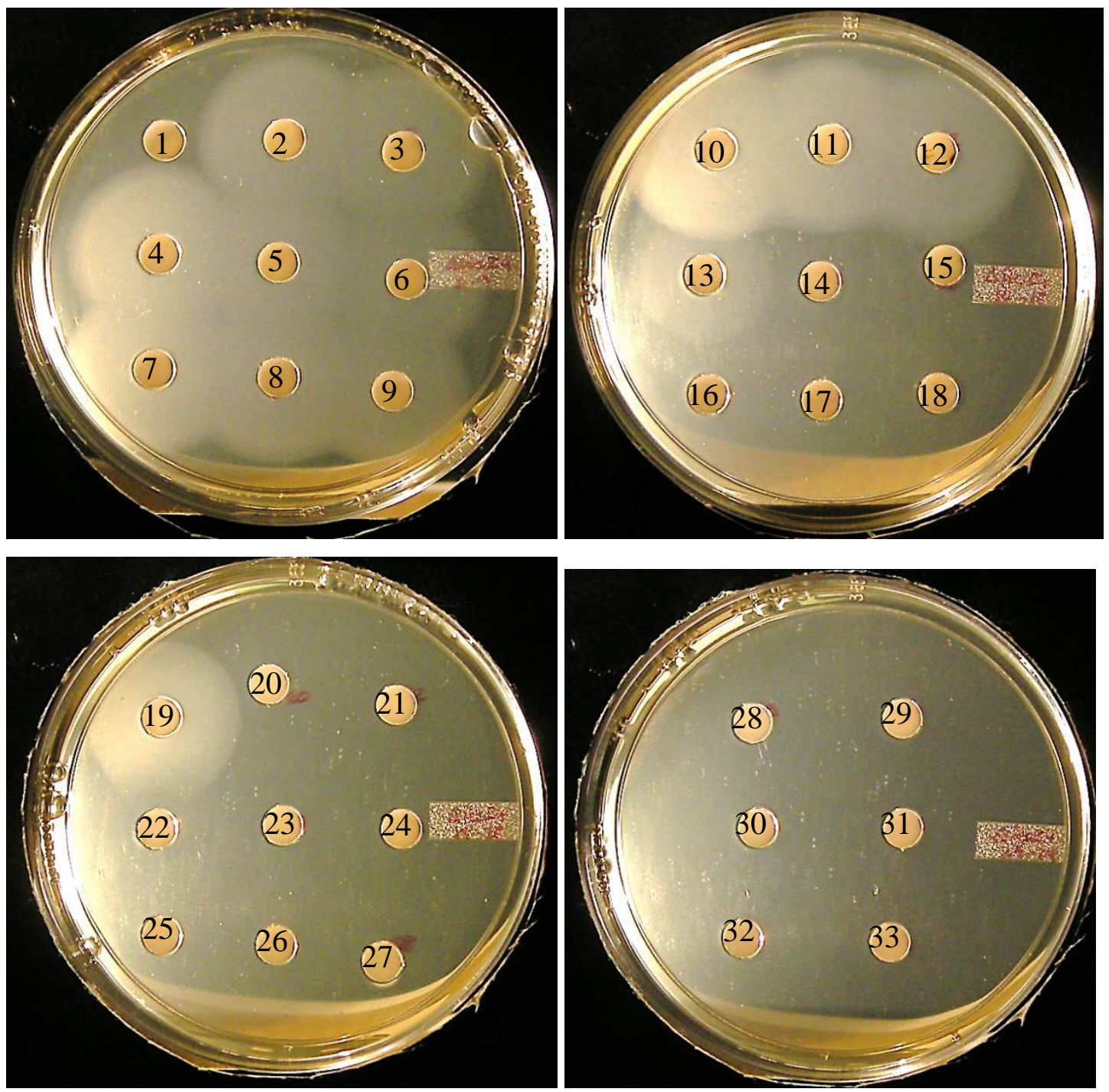

Figura 23 - Utilização de sideróforos por $C$. crescentus $\Delta$ fecI4. A legenda dos sideróforos encontrase na Tabela 4. 

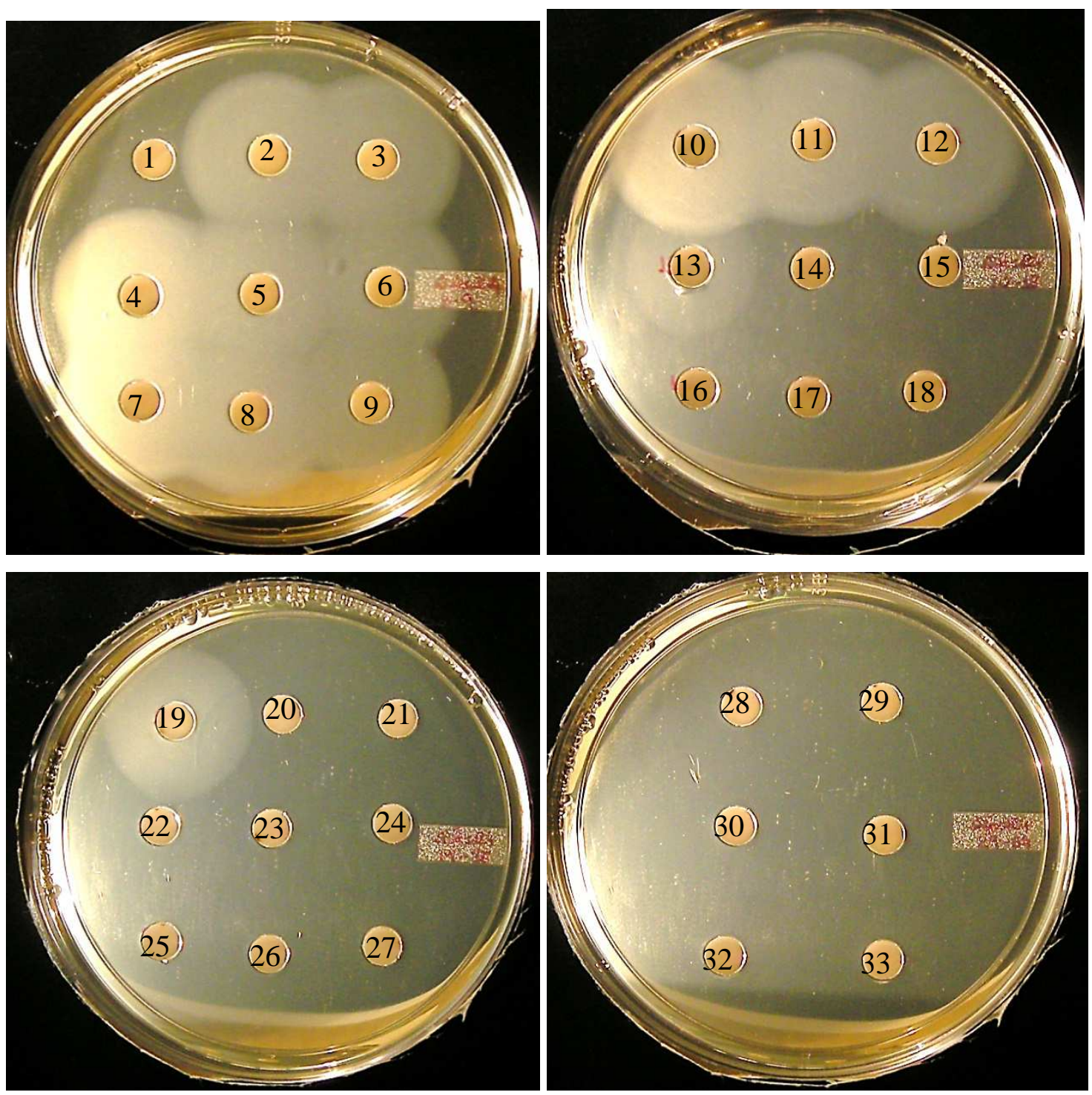

Figura 24 - Utilização de sideróforos por $C$. crescentus $\Delta$ fecR4. A legenda dos sideróforos encontra-se na Tabela 4. 
Tabela 5. Diâmetros de halos de crescimento $(\mathrm{em} \mathrm{cm})$ para cada linhagem de $C$. crescentus em testes de utilização de sideróforos.

\begin{tabular}{cccccc}
\hline Sideróforo & NA1000 $^{\boldsymbol{a}}$ & $\Delta \boldsymbol{f e c A ^ { b }}$ & $\Delta \boldsymbol{f e c R 2 ^ { b }}$ & $\Delta \boldsymbol{f e c I 4}^{\boldsymbol{a}}$ & $\Delta \boldsymbol{f e c R}^{\boldsymbol{a}}$ \\
\hline Aspercromo B1 & $2.90 \pm 0.14$ & 2.90 & 2.80 & $2.85 \pm 0.21$ & $2.70 \pm 0$ \\
Aspercromo B2 & $2.95 \pm 0.07$ & 3.20 & 2.90 & $2.70 \pm 0.14$ & $2.80 \pm 0$ \\
Aspercromo C & $2.95 \pm 0.07$ & 3.10 & 2.90 & $2.90 \pm 0.28$ & $2.95 \pm 0.07$ \\
Aspercromo D1 & $2.70 \pm 0$ & 2.50 & 2.40 & $2.60 \pm 0$ & $2.65 \pm 0.07$ \\
Ferricromo A & $2.65 \pm 0.07$ & 2.80 & 2.60 & $2.70 \pm 0.14$ & $2.65 \pm 0.07$ \\
Ferricromo C & $2.85 \pm 0.07$ & 2.90 & 2.60 & $2.80 \pm 0.28$ & $2.65 \pm 0.07$ \\
Ferricrisina & $2.95 \pm 0.07$ & 2.80 & 2.70 & $2.80 \pm 0.14$ & $2.85 \pm 0.07$ \\
Ferricrocina & $2.80 \pm 0$ & 2.80 & 2.70 & $2.75 \pm 0.21$ & $2.85 \pm 0.07$ \\
Ferrirrodina & $3.00 \pm 0.14$ & 3.10 & 2.90 & $2.85 \pm 0.21$ & $2.90 \pm 0.14$ \\
Ferrirrubina & $3.05 \pm 0.07$ & 3.00 & 2.90 & $2.90 \pm 0.28$ & $2.80 \pm 0.14$ \\
Malonicromo & $3.05 \pm 0.07$ & 2.90 & 2.80 & $2.85 \pm 0.21$ & $2.80 \pm 0.28$ \\
Ferricromo & $2.30 \pm 0.14$ & 2.50 & 2.20 & $2.15 \pm 0.21$ & $2.15 \pm 0.21$ \\
tetraglicina & & 2.70 & 2.60 & $2.70 \pm 0$ & $2.65 \pm 0.07$ \\
Ferricromo & $2.75 \pm 0.07$ & 2.90 & & &
\end{tabular}

${ }^{a}$ Os resultados são expressos como a média de dois experimentos, mostrando o desvio padrão.

${ }^{b}$ Os resultados derivam de um único experimento.

Os resultados obtidos indicam que nenhuma das mutações afetou a habilidade de $C$. crescentus de utilizar os sideróforos testados. Se os genes fecA2, fecI2, fecI4 e fecR4 fossem importantes para a captação dos sideróforos testados, ou para a regulação de vias envolvidas nesta captação, diferenças teriam sido observadas com relação ao crescimento nestas fontes de ferro. No entanto, este não foi o caso, corroborando a hipótese de que estes genes não estão envolvidos com o metabolismo de ferro em C. crescentus, como previamente argumentado.

Isto é incomum, uma vez que, até onde se sabe, todos os sistemas do tipo FEC descritos em outras bactérias estão envolvidos com captação de ferro ou biossíntese de sideróforos. Alguns fatores sigma de carência de ferro, contudo, foram descritos como respondendo a diversas condições, como virulência, fontes de carbono, tensão de oxigênio, carência de cobre, densidade populacional e contato célula-célula (FRANGIPANI et al., 2008; OCHSNER et al., 1996; STINTZI et al., 1998). No entanto, sua função primária ainda é relacionada à homeostase de ferro. 
Uma vez que uma grande variedade de sideróforos foi testada neste trabalho, é plausível que os sistemas FEC2 e FEC4 de C. crescentus não respondam a ferro de nenhuma maneira. Esta ideia é amparada pelos estudos de expressão gênica, fenótipos de crescimento e análises de microarranjos de cDNA (descritos no item 4.4).

Em suma, pode-se afirmar que $C$. crescentus consegue captar sideróforos e utilizá-los como fonte de ferro, mesmo após um período prolongado de carência de ferro. No entanto, nenhuma das linhagens mutantes analisadas neste trabalho apresenta defeitos fenotípicos relacionados à utilização de compostos férricos ou à resposta à carência deste metal, sugerindo que os genes analisados não estão envolvidos com a captação e utilização de ferro por esta bactéria.

\subsection{Determinação dos regulons}

Para se obter indícios mais claros dos alvos de regulação dos fatores sigma FecI2 e FecI4, foram realizadas análises por microarranjos de DNA dos mutantes $\Delta f e c R 2$ e $\Delta f e c R 4$. Nestes mutantes, é esperado que os fatores sigma se encontrem ativos independentemente do sinal a que respondem, e os genes alvo também estariam sendo constitutivamente expressos, em oposição ao que ocorre na linhagem parental NA1000, em que estes genes só teriam a expressão aumentada na presença do sinal de ativação do sigma.

Foi utilizada uma lâmina de microarranjo customizada para Caulobacter, conforme representado na figura 25, e os cDNAs utilizados foram gerados a partir de RNA extraído de culturas de NA1000, $\Delta f e c R 2$ e $\Delta f e c R 4$ em fase exponencial em meio mínimo M2. Considerou-se gene induzido nos mutantes aquele cuja expressão se encontra aumentada em duas vezes ou mais em relação a NA1000. O gene que possuía este grau de indução foi considerado um possível gene alvo do fator sigma ativado em cada linhagem. Para a análise feita neste trabalho, foram considerados os quatro últimos oligonucleotídeos de cada ORF para determinar a expressão relativa de um gene na linhagem mutante em relação a NA1000. Desse modo, assegurou-se que os oligonucleotídeos analisados se encontrassem dentro da região codificadora da ORF. 
Figura 25 - Design do experimento de microarranjo de cDNA. (A) Representação esquemática das hibridizações realizadas. Cada lâmina contém quatro grades, cada uma comportando uma hibridização. Foram realizadas duas replicatas técnicas de cada hibridização deste trabalho (sendo uma correspondente a NA1000 x $\Delta f e c R 2$ e uma correspondente a NA1000 x $\Delta f e c R 4)$. (B) Exemplo do resultado de um experimento de microarranjo de cDNA após hibridização e escaneamento da lâmina. Uma grade representando a hibridização NA1000 x $\Delta f e c R 2$ é mostrada juntamente com a representação visual de expressão gênica após escaneamento da lâmina. Pontos vermelhos representam predominância do corante Cy5 sobre Cy3, ou seja, predominância de cDNA da linhagem mutante sobre o da linhagem parental. Pontos verdes indicam a situação contrária, e pontos amarelos indicam igual concentração dos corantes, ou igual concentração de cDNAs das duas linhagens. Este trabalho focou nos casos de expressão gênica maior no mutante, ou seja, nos pontos vermelhos da lâmina. Cada ponto da lâmina representa um oligonucleotídeo específico que hibridiza com uma sequência curta do genoma (de, em média, 60 nucleotídeos), perfazendo mais de 45000 oligonucleotídeos; dessa forma, uma ORF de C. crescentus possui vários pontos correspondentes na lâmina. Estes oligonucleotídeos estão dispostos na forma de "tiling array", ou seja, apresentam-se com ligeira sobreposição entre si ao longo de uma sequência (abaixo na figura). A lâmina específica para C. crescentus contém oligonucleotídeos que hibridizam com regiões a montante de ORFs anotadas e o início das próprias ORFs desta bactéria; portanto, sequências não codificantes e codificantes estão representadas. Como a hibridização desta lâmina foi feita com cDNAs, apenas a região transcrita de uma dada ORF é sujeita à hibridização, que ocorre desde o sítio de início de transcrição do RNA (TSS, do inglês transcription start site) até o término da ORF, incluindo o códon de iniciação da tradução (ATG). As posições relativas no genoma, representadas na figura, são meramente ilustrativas. 


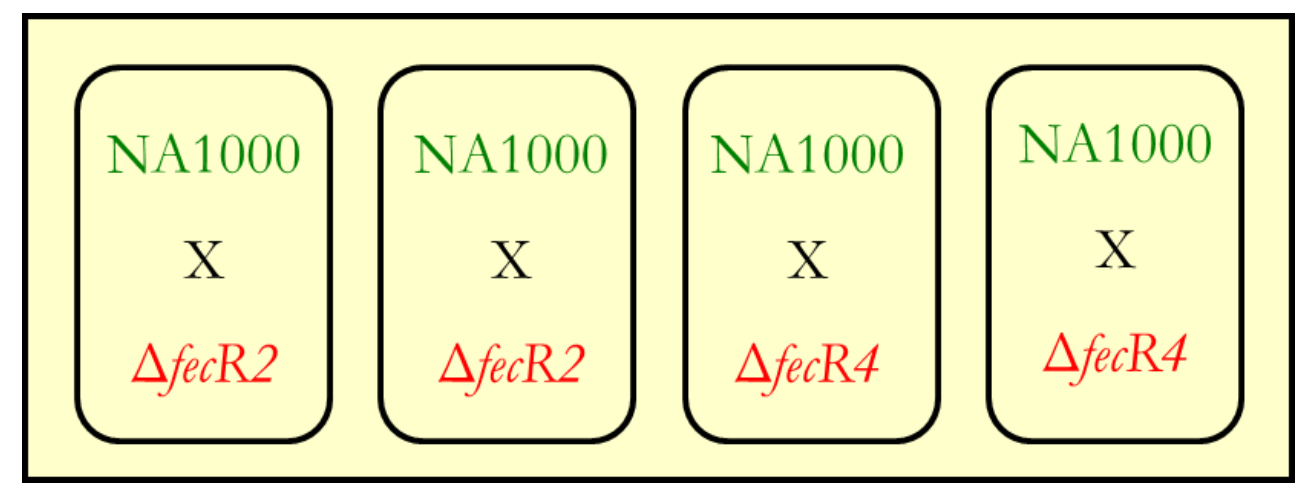

(A)

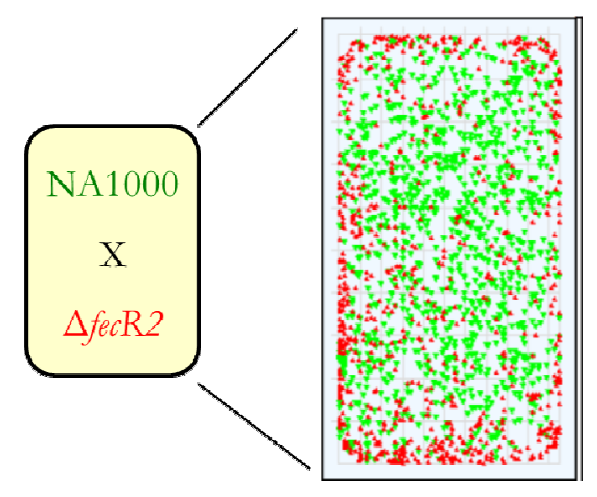

- Cy5 > Cy3 (mut. > NA1000)

- Cy3 > Cy5 (NA1000> mut.)

- Cy3 = Cy5 (NA1000 = mut.)

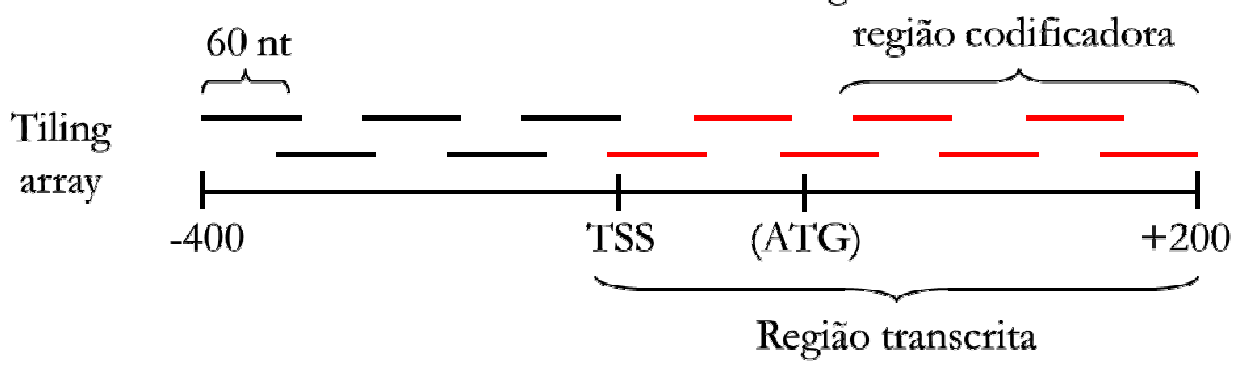

(B) 
Para o mutante $\Delta f e c R 2$, foi observado apenas um gene induzido, que é o gene $f e c A 2$ (CCNA_01189 ou CC1131). A média de indução observada foi de 5,39 vezes em relação a NA1000. Esta indução já havia sido observada neste trabalho por ensaio de atividade de $\beta$ galactosidase em PYE (Fig. 10A), inclusive com nível semelhante. Este gene por si só não fornece informações a respeito da via regulada pelo sigma FecI2, pois não se sabe o que o receptor FecA2 transporta, ou a que sinal responde. Para se ter uma noção mais clara do papel do sistema FEC2, buscou-se verificar em que condições o crescimento celular da linhagem $\triangle f e c A 2$ poderia ser afetado. Esta condição seria o primeiro passo para a identificação do sinal ativador do sistema FEC2. Esta análise não forneceu dados informativos, uma vez que este mutante também não teve uma resposta diferenciada frente à presença ou carência de fontes de ferro (ver item 4.3). Uma análise de maior espectro, realizada através de microarranjos fenotípicos, se encontra descrita no item 4.5.

A presença de apenas um gene reprodutivelmente induzido em $\Delta f e c R 2$ não é inesperada, uma vez que os fatores sigma do tipo FEC mais estudados em outras bactérias também possuem um regulon bem restrito. FecI de E. coli reconhece apenas o promotor à frente do operon $f e c A B C D E$, enquanto FpvI de $P$. aeruginosa reconhece o promotor a montante do gene $f p v A$, que codifica o receptor do sideróforo pioverdina (ANDREWS; ROBINSON; RODRIGUEZ-QUINONES, 2003). Mesmo PvdS de $P$. aeruginosa, que regula uma quantidade maior de genes, tem como regulon genes relacionados com a síntese do sideróforo pioverdina, o gene que codifica a exotoxina A e o gene codificando a protease secretada PrpL (VISCA et al., 2002).

Já na linhagem $\Delta f e c R 4$, a quantidade de genes induzidos se mostrou muito maior: mais de 50 ORFs tiveram níveis de expressão maiores no mutante (Tabela 6). Este é um número surpreendentemente alto de genes regulados por um fator sigma do tipo Fec. Dentre os genes presumivelmente regulados por FecI4, existem vários transportadores, inclusive receptores dependentes de TonB (CCNA_02910 e CCNA_03108); no entanto, não aparece induzido o gene fecA4 (CCNA_00597), como esperado. Isto seria mais uma evidência de que o receptor FecA4 não faz parte da via de regulação coordenada pelo fator sigma FecI4. 
Tabela 6. Genes induzidos na linhagem $\Delta f e c R 4$ observados na análise de microarranjos de cDNA. Os valores representam a expressão relativa de um gene em $\Delta f e c R 4$ em relação a NA1000. São mostradas as anotações de CB15 e de NA1000. Em azul, genes relacionados a transporte; em vermelho, a metabolismo ou biossíntese de compostos carbônicos; em preto, a outras funções ou codificando proteínas hipotéticas.

\begin{tabular}{|c|c|c|c|c|}
\hline $\begin{array}{c}\text { Anotação } \\
\text { CB15 }\end{array}$ & $\begin{array}{l}\text { Anotação } \\
\text { NA1000* }\end{array}$ & $\begin{array}{c}\text { Expressão } \\
\text { relativa }\end{array}$ & $\begin{array}{l}\text { Categoria } \\
\text { funcional }\end{array}$ & Produto do gene \\
\hline CC0064 & CCNA_00062 & 3,09 & $\begin{array}{c}\text { Biossíntese de } \\
\text { aminoacil-tRNA }\end{array}$ & Triptofanil-tRNA sintetase \\
\hline $\mathrm{CC0262}$ & CCNA_00263 & 5,90 & & Proteína hipotética \\
\hline CC0411 & CCNA_00416 & 3,81 & & Proteína hipotética \\
\hline $\mathrm{CC0555}$ & CCNA_00590 & 2,68 & & $\begin{array}{l}\text { Flavoproteína desidrogenase da } \\
\text { família FixC }\end{array}$ \\
\hline CC0558 & CCNA_00593 & 3,18 & & Proteína hipotética \\
\hline CC0559 & CCNA_00594 & 5,63 & & Proteína hipotética \\
\hline CC0679 & CCNA_00718 & 3,54 & & Proteína de infecção abortiva \\
\hline $\mathrm{CC0680}$ & - & 3,84 & & Proteína hipotética \\
\hline CC0681 & - & 5,65 & & Proteína hipotética \\
\hline $\mathrm{CC0682}$ & - & 5,61 & & Proteína hipotética \\
\hline CC0781 & CCNA_00822 & 3,65 & & Proteína hipotética \\
\hline $\mathrm{CC0925}$ & CCNA_00974 & 4,29 & Transporte & $\begin{array}{c}\text { Proteína OmpA-like; proteína } \\
\text { OAR }\end{array}$ \\
\hline CC1040 & CCNA_01092 & 9,80 & & $\begin{array}{c}\text { Proteína com domínio ACT de } \\
\text { ligação a aminoácidos }\end{array}$ \\
\hline CC1041 & CCNA_01093 & 14,69 & & Proteína hipotética \\
\hline CC1098 & CCNA_01154 & 3,77 & & Proteína hipotética \\
\hline CC1396 & CCNA_01462 & 13,00 & $\begin{array}{l}\text { Metabolismo/ } \\
\text { biossíntese } \\
\text { de compostos } \\
\text { carbônicos }\end{array}$ & $\begin{array}{l}\text { L-lactate 2-monooxigenase } \\
\text { (Metabolismo de piruvato) }\end{array}$ \\
\hline CC1397 & CCNA_01463 & 16,40 & $\begin{array}{l}\text { Metabolismo/ } \\
\text { biossíntese de } \\
\text { aminoácidos }\end{array}$ & $\begin{array}{l}\text { 3-deoxi-7-fosfoheptulonato } \\
\text { sintase } \\
\text { (Biossíntese de fenilalanina, } \\
\text { tirosina e triptofano) }\end{array}$ \\
\hline CC1628 & CCNA_01700 & 2,80 & Transporte & Nucleosídeo permease \\
\hline
\end{tabular}

(Continua) 
Tabela 6. Genes induzidos na linhagem $\Delta f e c R 4$ observados na análise de microarranjos de cDNA. (Continuação)

\begin{tabular}{|c|c|c|c|c|}
\hline $\begin{array}{c}\text { Anotação } \\
\text { CB15 }\end{array}$ & $\begin{array}{l}\text { Anotação } \\
\text { NA1000* }\end{array}$ & $\begin{array}{c}\text { Expressão } \\
\text { relativa }\end{array}$ & $\begin{array}{l}\text { Categoria } \\
\text { funcional }\end{array}$ & Produto do gene \\
\hline CC1630 & CCNA_01702 & 3,65 & & $\begin{array}{l}\text { Oxidorredutase dependente de } \\
\text { NAD }\end{array}$ \\
\hline CC1631 & CCNA_01703 & 4,41 & & Proteína IolE-like \\
\hline CC1635 & CCNA_01707 & 2,68 & $\begin{array}{c}\text { Metabolismo/ } \\
\text { biossíntese } \\
\text { de compostos } \\
\text { carbônicos }\end{array}$ & $\begin{array}{c}\text { Proteína da família gluconato 2- } \\
\text { desidrogenase subunidade } 3\end{array}$ \\
\hline CC1764 & CCNA_01841 & 5,57 & $\begin{array}{c}\text { Metabolismo/ } \\
\text { biossíntese } \\
\text { de compostos } \\
\text { carbônicos }\end{array}$ & Isocitrato liase \\
\hline CC1765 & CCNA_01843 & 8,06 & $\begin{array}{c}\text { Metabolismo/ } \\
\text { biossíntese } \\
\text { de compostos } \\
\text { carbônicos }\end{array}$ & Malato sintase \\
\hline CC1896 & CCNA_01973 & 2,45 & & Proteína hipotética \\
\hline CC2119 & CCNA_02203 & 2,67 & & $\begin{array}{c}\text { Proteína com domínio } \\
\text { semelhante a YceI }\end{array}$ \\
\hline CC2200 & CCNA_02283 & 4,01 & & HNH endonuclease \\
\hline CC2407 & CCNA_02490 & 2,96 & $\begin{array}{l}\text { Metabolismo de } \\
\text { compostos } \\
\text { aromáticos }\end{array}$ & $\begin{array}{c}\text { 3-cetoacil-CoA tiolase } \\
\text { (Degradação de benzoato) }\end{array}$ \\
\hline CC2409 & CCNA_02492 & 2,77 & $\begin{array}{l}\text { Metabolismo de } \\
\text { compostos } \\
\text { aromáticos }\end{array}$ & $\begin{array}{c}\text { Protocatecuato 3,4-dioxigenase } \\
\text { subunidade alfa } \\
\text { (Degradação de benzoato e } \\
\text { hidrocarbonetos policíclicos } \\
\text { aromáticos) }\end{array}$ \\
\hline CC2532 & CCNA_02615 & 3,11 & $\begin{array}{l}\text { Metabolismo/ } \\
\text { biossíntese de } \\
\text { aminoácidos }\end{array}$ & $\begin{array}{l}\text { Homogentisato 1,2-dioxigenase } \\
\text { (Metabolismo de tirosina; } \\
\text { degradação de estireno) }\end{array}$ \\
\hline
\end{tabular}


Tabela 6. Genes induzidos na linhagem $\Delta f e c R 4$ observados na análise de microarranjos de cDNA. (Continuação)

\begin{tabular}{|c|c|c|c|c|}
\hline $\begin{array}{c}\text { Anotação } \\
\text { CB15 }\end{array}$ & $\begin{array}{l}\text { Anotação } \\
\text { NA1000* }\end{array}$ & $\begin{array}{c}\text { Expressão } \\
\text { relativa }\end{array}$ & $\begin{array}{l}\text { Categoria } \\
\text { funcional }\end{array}$ & Produto do gene \\
\hline $\mathrm{CC} 2533$ & CCNA_02616 & 5,70 & $\begin{array}{l}\text { Metabolismo/ } \\
\text { biossíntese de } \\
\text { aminoácidos }\end{array}$ & $\begin{array}{c}\text { 4-hidroxifenilpiruvato } \\
\text { dioxigenase (Biossíntese de } \\
\text { ubiquinona e outros } \\
\text { terpenóides-quinonas; } \\
\text { metabolismo de tirosina e } \\
\text { fenilalanina) }\end{array}$ \\
\hline $\mathrm{CC2597}$ & - & 3,17 & & Proteína hipotética \\
\hline CC2644 & CCNA_02727 & 6,99 & & Proteína semelhante a PhoH \\
\hline CC2645 & CCNA_02728 & 5,69 & & Proteína hipotética \\
\hline $\mathrm{CC2646}$ & CCNA_02729 & 2,51 & Transporte & $\begin{array}{c}\text { Transportador de oligopeptídeo } \\
\text { da família OPT }\end{array}$ \\
\hline $\mathrm{CC2679}$ & CCNA_02761 & 2,37 & & Proteína hipotética \\
\hline $\mathrm{CC2696}$ & CCNA_02779 & 2,56 & & $\begin{array}{c}\text { Proteína de ligação a } \\
\text { peptidioglicano da família } \\
\text { LysM }\end{array}$ \\
\hline CC2697 & CCNA_02780 & 2,91 & & Proteína hipotética \\
\hline CC2745 & CCNA_02831 & 2,97 & & Proteína hipotética \\
\hline CC2819 & $\begin{array}{c}\text { CCNA_02910* } \\
*\end{array}$ & 4,00 & Transporte & Receptor dependente de TonB \\
\hline $\mathrm{CC2820}$ & $\begin{array}{c}\text { CCNA_02910* } \\
*\end{array}$ & 3,46 & Transporte & Receptor dependente de TonB \\
\hline CC2838 & CCNA_02930 & 2,54 & & Endonuclease \\
\hline CC3013 & CCNA_03108 & 4,84 & Transporte & Receptor dependente de TonB \\
\hline CC3043 & CCNA_03138 & 4,64 & & Catalase/peroxidase \\
\hline CC3085 & CCNA_03181 & 2,49 & $\begin{array}{c}\text { Metabolismo/ } \\
\text { biossíntese } \\
\text { de compostos } \\
\text { carbônicos }\end{array}$ & Álcool desidrogenase \\
\hline CC3096 & CCNA_03193 & 2,26 & & Lactoilglutationa liase \\
\hline
\end{tabular}

(Continua) 
Tabela 6. Genes induzidos na linhagem $\Delta f e c R 4$ observados na análise de microarranjos de cDNA. (Continuaçã̃o)

\begin{tabular}{|c|c|c|c|c|}
\hline $\begin{array}{c}\text { Anotação } \\
\text { CB15 }\end{array}$ & $\begin{array}{l}\text { Anotação } \\
\text { NA1000* }\end{array}$ & $\begin{array}{c}\text { Expressão } \\
\text { relativa }\end{array}$ & $\begin{array}{l}\text { Categoria } \\
\text { funcional }\end{array}$ & Produto do gene \\
\hline CC3126 & CCNA_03226 & 4,54 & Transporte & $\begin{array}{c}\text { Antiporter } \\
\text { aminoácido/poliamina }\end{array}$ \\
\hline CC3131 & CCNA_03232 & 3,35 & & Proteína toxina relE-4 \\
\hline CC3218 & CCNA_03325 & 2,70 & & Proteína hipotética \\
\hline CC3287 & CCNA_03396 & 2,35 & & Serina protease \\
\hline CC3302 & - & 5,14 & & Proteína hipotética \\
\hline CC3399 & CCNA_03510 & 4,61 & $\begin{array}{c}\text { Metabolismo/ } \\
\text { biossíntese } \\
\text { de compostos } \\
\text { carbônicos }\end{array}$ & Treonina sintase \\
\hline CC3400 & CCNA_03511 & 4,16 & & $\begin{array}{c}\text { Proteína SurF1 de montagem da } \\
\text { citocromo c oxidase }\end{array}$ \\
\hline CC3401 & CCNA_03512 & 3,59 & & Proteína zinc-finger \\
\hline CC3710 & CCNA_03825 & 2,59 & & Proteína hipotética \\
\hline CC3711 & CCNA_03826 & 2,76 & & Proteína hipotética \\
\hline
\end{tabular}

(Conclusão)

* Não há ORFs correspondentes em NA1000 para CC0680, CC0681, CC0682, CC2597 e CC3302. ** A ORF CCNA_02910 corresponde à anotação de duas ORFs de CB15 juntas (CC2819 e CC2820). 
Um dos receptores dependentes de TonB induzidos em $\Delta f e c R 4$ poderia ser aquele que participa da via de sinalização que levaria à liberação do fator sigma FecI4, de acordo com o modelo de fatores sigma de carência de ferro. Dada a proximidade de fecA4 com fecI4 e fecR4, seria esperado que este gene fosse o ortólogo de fecA de E. coli neste cluster. Surpreendentemente, este não é o caso, e os resultados dos microarranjos de cDNA forneceram outras possibilidades para este papel, já que outros receptores dependentes de TonB podem ser ativados por FecI4.

A categoria funcional mais presente dentre os genes observados é utilização de carbono. Pelo menos 10 genes da lista possuem função direta relacionada com metabolismo ou biossíntese de compostos carbônicos; em especial, há um número representativo de genes relacionados ao metabolismo ou biossíntese de aminoácidos. Duas dessas ORFs (CCNA_02490 e CCNA_02492) pertencem a um cluster gênico cuja função é anotada como degradação de benzoato (CCNA_02487-CCNA_02495), o que poderia ser um indicativo de que a ativação de FecI4 leva à ativação da via de degradação de benzoato. No entanto, ensaios de crescimento com benzoato de sódio como fonte de carbono não mostraram crescimento de C. crescentus, e com a utilização de compostos relacionados (vanilato e 4-hidroxibenzoato de sódio), mostraram taxas de crescimento similares entre a linhagem parental e o mutante $\Delta f e c I 4$ (dados não mostrados), sugerindo que os genes envolvidos na utilização de compostos derivados do benzoato não são diretamente regulados por FecI4.

É importante salientar que nenhum gene induzido na linhagem $\Delta f e c R 4$ está diretamente relacionado com o metabolismo de ferro. Isto seria mais uma evidência de que o fator sigma FecI4, apesar de pertencer à mesma família dos fatores sigma de carência de ferro, não coordena genes envolvidos na homeostase de ferro.

As análises por microarranjos de DNA se mostraram extremamente úteis para averiguar a função do fator sigma FecI4. Apesar de sua função ainda não ter sido totalmente esclarecida, as possibilidades se encontram mais restritas. Os dados indicam, em seu conjunto, que este fator sigma coordena atividades celulares relacionadas à utilização de carbono.

Já no caso da linhagem $\Delta f e c R 2$, as análises por microarranjo não forneceram informações novas sobre a linha de regulação de FecI2. A indução de fecA2 no mutante já havia sido vista por ensaios de atividade de $\beta$-galactosidase, e o microarranjo apenas corroborou esta indução. Este gene por si só não fornece informações a respeito da via regulada pelo sigma FecI2, pois não se sabe o que o receptor FecA2 transporta, ou a que sinal responde. $\mathrm{O}$ mutante $\triangle f e c A 2$ foi construído justamente para se ter uma noção mais clara do papel do sistema FEC2, através da análise das condições em que o crescimento deste mutante 
pudesse ser afetado. No entanto, em vários experimentos de avaliação do crescimento na presença ou carência de fontes de ferro diversas, o mutante $\Delta f e c A 2$ apresentou fenótipo semelhante à linhagem parental NA1000 (Fig. 15, 16 e 21).

A fim de se validar alguns dos resultados obtidos por microarranjos, foram realizados experimentos de PCR quantitativo em tempo real (qRT-PCR). Treze genes que se mostraram induzidos na linhagem $\Delta f e c R 4$ foram escolhidos para esta validação, dando-se preferência a genes com alto nível de indução e com função anotada. Para isso, foram desenhados oligonucleotídeos que hibridizam na região codificadora de cada gene, amplificando fragmentos de pouco mais de $100 \mathrm{pb}$. Os cDNAs utilizados como molde provieram de culturas de NA1000 ou $\Delta f e c R 4$ incubadas em meio M2 até uma $\mathrm{DO}_{600}$ de aproximadamente 1,0 (condições iguais às dos cDNAs gerados para os microarranjos). Utilizou-se como normalizador do experimento a ORF CCNA_00217, que codifica DsbD, uma proteína envolvida em reações de oxidorredução tiol:dissulfeto, cuja expressão se encontra inalterada em $\Delta f e c R 4$ em comparação com NA1000 nos microarranjos.

Seis dos treze genes escolhidos foram validados por qRT-PCR (Tabela 7). No entanto, para este tipo de experimento, não foi analisada a eficiência dos oligonucleotídeos utilizados; em vez disso, a expressão relativa dos genes foi obtida assumindo-se que os oligonucleotídeos possuíam uma eficiência de hibridização igual a 100\%. Portanto, uma avaliação cautelosa da eficiência dos oligonucleotídeos utilizados se faz necessária para uma validação mais robusta. Os genes validados também tiveram sua expressão avaliada no mutante $\Delta f e c I 4$. Nesta linhagem, é esperado que a expressão dos genes induzidos em $\Delta f e c R 4$ volte aos níveis da linhagem parental, já que tanto em NA1000 quanto em $\Delta f e c I 4$ o fator sigma FecI4 está inativo (por ausência de sinal ativador em NA1000 e por mutação em $\Delta f e c I 4$ ). Logo, a expressão relativa $\Delta f e c I 4 / \mathrm{NA} 1000$ deve ser menor que a expressão relativa $\Delta f e c R 4 / \mathrm{NA} 1000$ e ter valor próximo a 1. Para os genes validados em $\Delta f e c R 4$, houve queda na expressão relativa $\Delta f e c I 4 / N A 1000$ em relação a $\Delta f e c R 4 / N A 1000$, aumentando a robustez da validação e corroborando o envolvimento do fator sigma FecI4 em sua regulação (Tabela 7). 
Tabela 7. Expressão relativa de genes por RT-PCR quantitativo. Os valores representam a expressão relativa de cada gene na linhagem mutante indicada em relação a NA1000. Genes em negrito indicam aqueles considerados validados. ND, não determinado. Os dados representam a média de dois experimentos, com o desvio padrão indicado. Para comparação, os valores de indução obtidos na análise por microarranjos de cDNA também são mostrados.

\begin{tabular}{|c|c|c|c|c|c|}
\hline $\begin{array}{c}\text { Gene } \\
\text { (anotação } \\
\text { CB15) }\end{array}$ & $\begin{array}{c}\text { Gene (anotação } \\
\text { NA1000) }\end{array}$ & Produto & $\begin{array}{c}\text { Expressão } \\
\text { relativa } \\
\Delta \text { fecR4/NA1000 }\end{array}$ & $\begin{array}{c}\text { Expressão } \\
\text { relativa } \\
\Delta \text { fecI4/NA1000 }\end{array}$ & $\begin{array}{c}\text { Indução nos } \\
\text { microarranjos } \\
(\Delta f e c R 4 / \mathrm{NA1000})\end{array}$ \\
\hline CC0559 & CCNA_00594 & $\begin{array}{c}\text { Proteína } \\
\text { hipotética }\end{array}$ & $2,37 \pm 0,64$ & $1,26 \pm 1,07$ & 5,6 \\
\hline CC0682 & - & $\begin{array}{l}\text { Proteína } \\
\text { hipotética }\end{array}$ & $2,61 \pm 0,36$ & $1,47 \pm 0,98$ & 5,6 \\
\hline CC1041 & CCNA_01093 & $\begin{array}{c}\text { Proteína } \\
\text { hipotética }\end{array}$ & $1,74 \pm 0,21$ & ND & 14,7 \\
\hline CC1397 & CCNA_01463 & $\begin{array}{c}\text { 3-deoxi-7- } \\
\text { fosfoheptulona-to } \\
\text { sintase }\end{array}$ & $9,65 \pm 0,19$ & $3,59 \pm 2,44$ & 16,4 \\
\hline $\mathrm{CC} 1635$ & CCNA_01707 & $\begin{array}{c}\text { Proteína da } \\
\text { família gluconato } \\
\text { 2-desidrogenase } \\
\text { subunidade } 3\end{array}$ & $1,85 \pm 1,01$ & ND & 2,7 \\
\hline $\mathrm{CC} 1765$ & CCNA_01843 & Malato sintase & $1,63 \pm 0,04$ & ND & 8,1 \\
\hline $\mathrm{CC} 2200$ & CCNA_02283 & $\begin{array}{c}\text { HNH } \\
\text { endonuclease }\end{array}$ & $0,41 \pm 0,08$ & ND & 4,0 \\
\hline CC2409 & CCNA_02492 & $\begin{array}{l}\text { Protocatecuato } \\
\text { 3,4-dioxigenase } \\
\text { subunidade alfa }\end{array}$ & $1,49 \pm 0,08$ & ND & 2,8 \\
\hline $\mathrm{CC} 2532$ & CCNA_02615 & $\begin{array}{l}\text { Homogentisato } \\
\text { 1,2-dioxigenase }\end{array}$ & $0,98 \pm 0,05$ & ND & 3,1 \\
\hline CC3013 & CCNA_03108 & $\begin{array}{c}\text { Receptor } \\
\text { dependente de } \\
\text { TonB }\end{array}$ & $3,38 \pm 0,69$ & $2,68 \pm 2,19$ & 4,8 \\
\hline CC3043 & CCNA_03138 & $\begin{array}{c}\text { Catalase/ } \\
\text { peroxidase }\end{array}$ & $2,03 \pm 0,36$ & $1,12 \pm 0,69$ & 4,6 \\
\hline CC3085 & CCNA_03181 & $\begin{array}{c}\text { Álcool } \\
\text { desidrogenase }\end{array}$ & $1,04 \pm 0,47$ & ND & 2,49 \\
\hline CC3399 & CCNA_03510 & Treonina sintase & $2,08 \pm 0,42$ & $1,15 \pm 0,50$ & 4,61 \\
\hline
\end{tabular}


A ORF CCNA_01463 apresentou a indução mais alta dos microarranjos de cDNA, de $16,4$ vezes ( $\Delta f e c R 4 / \mathrm{NA} 1000)$, com altos níveis de indução também na validação por qRTPCR (Tabela 7). O produto deste gene é uma enzima envolvida na biossíntese de aminoácidos, notadamente fenilalanina, tirosina e triptofano. A reação catalisada por esta enzima faz parte de uma via que gera corismato, um precursor para a biossíntese de vários outros compostos em micro-organismos, entre eles, os aminoácidos mencionados e, notadamente, enterobactina (CROSA; WALSH, 2002). Entretanto, não se sabe se o papel desta enzima em $C$. crescentus estaria relacionado à produção de algum sideróforo, já que outros componentes cruciais destas vias de biossíntese não estão presentes no genoma desta bactéria (NIERMAN et al., 2001).

A ORF anotada como CC0682 em CB15, sem anotação correspondente em NA1000, é de especial interesse dentre os genes validados. Esta ORF corresponde, em NA1000, a uma sequência contida em um pequeno RNA não codificante de 1 kb (CCNA_R0117), contendo também a sequência correspondente à ORF CC0681 anotada em CB15 (SCHRADER et al., 2014). CCNA_R0117 se mostrou induzido tanto por limitação de ferro quanto pela mutação em fur, sugerindo um papel na homeostase de ferro em C. crescentus (DA SILVA NETO; LOURENÇO; MARQUES, 2013).

O receptor dependente de TonB codificado por CCNA_03108 não foi observado como induzido em análises transcricionais globais de $C$. crescentus em carência de ferro ou na linhagem mutante $\Delta$ fur (DA SILVA NETO; LOURENÇO; MARQUES, 2013). De fato, apenas a ORF CC0682, dentre os genes validados, aparece como induzida nestas condições naquele trabalho. Portanto, a ausência de genes relacionados à homeostase de ferro na lista dos induzidos em $\Delta f e c R 4$ permanece como norma.

Dentre as proteínas hipotéticas, CCNA_00594 foi uma das escolhidas para validação pela proximidade no genoma com o sistema FEC4, estando separada do gene fecR4 (CCNA_00595) apenas por um sRNA (CCNA_R0112), cuja função é desconhecida (LANDT et al., 2008). A jusante de CCNA_00594, há CCNA_00593 (codificando outra proteína hipotética induzida nos microarranjos de $\Delta f e c R 4$ ), outro sRNA de função desconhecida (CCNA_R0111) e um operon (CCNA_00592 - CCNA_00589) (SCHRADER et al., 2014). Contida neste operon, a ORF CCNA_00592 codifica uma proteína da família das ferritinas, que são proteínas globulares que armazenam íons ferro em seu interior como forma de reserva deste metal (ANDREWS; ROBINSON; RODRIGUEZ-QUINONES, 2003). No entanto, apenas CCNA_00590 se mostrou induzida nos microarranjos de $\Delta f e c R 4$, e esta ORF codifica uma desidrogenase com domínio de ligação a FAD (ELY; SCOTT, 2014). Esta ORF não está 
no início do operon, mas esta indução em $\Delta f e c R 4$ não depende necessariamente da presença de um promotor adicional interno ao operon; em contrapartida, isto pode indicar que este gene está sujeito a outros níveis de regulação não detectáveis nos microarranjos, como aqueles exercidos por sRNAs. Não se deve descartar a hipótese de que algum sRNA deste locus seja regulado pelo fator sigma FecI4; contudo, isto não é passível de observação nos experimentos realizados, pois estes elementos genômicos não são representados nas lâminas de microarranjos.

Também validado nos experimentos de qRT-PCR, katG é o gene correspondente à ORF CCNA_03138, codificando uma catalase/peroxidase, cuja função é a de remover o peróxido de hidrogênio intracelular produzido pelo metabolismo aeróbio. Fur é um importante agente na coordenação entre o metabolismo de ferro e o estresse oxidativo; porém, em $C$. crescentus, Fur não participa da regulação de katG (ITALIANI et al., 2011).

Os dados indicam que as ORFs CCNA_00594, CC0682 (sem correspondente anotado em NA1000), CCNA_01463, CCNA_03108, CCNA_03138 e CCNA_03510 podem exibir regulação direta pelo fator sigma FecI4. No entanto, como estes genes pertencem a diversas categorias funcionais, a relevância fisiológica de FecI4 ainda não é clara. É possível que este fator sigma tenha uma função fisiológica mais generalizada, contrariando o modelo exibido por diversos outros fatores sigma do tipo FecI, cujos regulons são extremamente especializados.

Apesar do grande número de genes induzidos em $\Delta f e c R 4$, não se sabe se estes são diretamente regulados por FecI4 e quais seriam parte de cascatas regulatórias. No entanto, como não há reguladores transcricionais óbvios entre os genes induzidos (Tabela 6), alguns genes foram considerados como diretamente regulados por FecI4 para se obter um consenso do promotor reconhecido por este fator sigma.

Os genes validados (em negrito na Tabela 7) foram utilizados como molde para busca de seqüências promotoras reconhecidas pelo fator sigma FecI4. Para isso, considerou-se que a indução destes genes na linhagem $\Delta f e c R 4$ fosse devida a uma regulação direta pelo fator sigma FecI4, e não fruto de cascatas regulatórias indiretas. Para cada um destes genes, seqüências a montante foram analisadas através da ferramenta MEME (BAILEY et al., 2009). O consenso encontrado mais condizente com um promotor é mostrado na figura 26.

Este motivo condiz com a região -35 reconhecida por fatores sigma ECF, pois possui alta conservação de bases A e C (HELMANN, 2002). Realizou-se uma busca por este consenso na lista de genes induzidos em $\Delta f e c R 4$, utilizando a ferramenta RSAT (Regulatory Sequence Analysis Tools) (THOMAS-CHOLLIER et al., 2008). Analisando-se os genes 
obtidos nesta busca que também se encontram induzidos em $\Delta f e c R 4$, encontrou-se o consenso nas regiões a montante dos genes CCNA_01707 e CCNA_02283, codificando, respectivamente, uma proteína da família gluconato 2-desidrogenase subunidade 3 e uma endonuclease. No entanto, ensaios de validação destes genes por qRT-PCR não foram bemsucedidos, uma vez que a expressão destes em $\Delta f e c R 4$ não foi alta o suficiente para considerálos validados (Tabela 7). Em contrapartida, o consenso não foi encontrado a montante do próprio gene $\mathrm{fecI}$, apoiando a ausência de autorregulação deste fator sigma, como averiguado anteriormente por ensaios de atividade de $\beta$-galactosidase (Fig. 11).

Dado que os prováveis genes-alvo de FecI4, inferidos por microarranjos de cDNA, pertencem a diversas categorias funcionais, a relevância fisiológica deste fator sigma ainda é desconhecida. É possível que FecI4 tenha uma função mais ampla do que o modelo de fatores sigma de carência de ferro, cujos regulons são extremamente estritos e especializados. Levando-se em consideração que vários genes envolvidos no metabolismo e biossíntese de compostos carbônicos são possíveis alvos de FecI4, recorreu-se a um microarranjo fenotípico em busca de compostos carbônicos envolvidos com a regulação promovida por FecI4 (item 4.5).

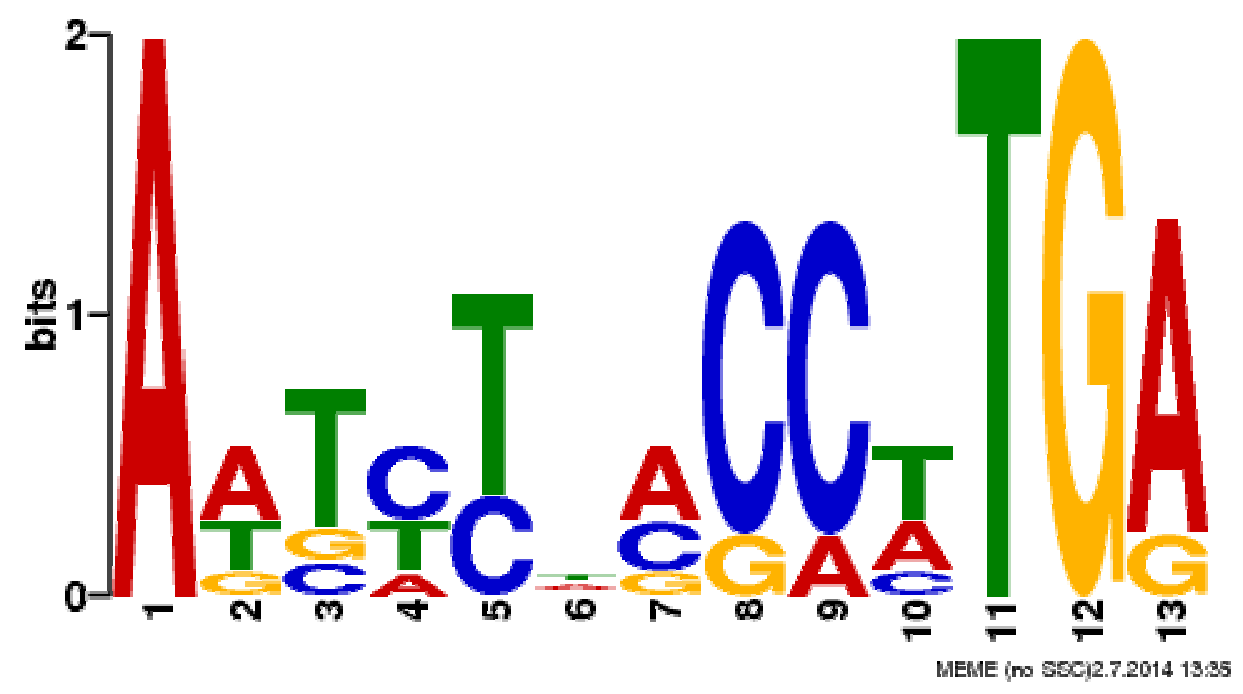

Figura 26 - Provável sequência promotora reconhecida pelo fator sigma FecI4. Os seis genes validados por qRT-PCR tiveram suas regiões regulatórias analisadas em busca de motivos condizentes com um promotor em comum. Gerado através da ferramenta MEME, este foi o motivo comum mais condizente com a região -35 de um promotor reconhecido por fator sigma ECF. A altura das letras representa a frequência do nucleotídeo correspondente na posição indicada. 


\subsection{Estudo das fontes de carbono utilizadas por $C$. crescentus}

De modo a se obter de modo rápido indícios dos sinais que ativam os fatores sigma FecI2 e FecI4, foram utilizadas microplacas Biolog, que consistem em placas de 96 poços contendo diferentes compostos (podendo ser carbônicos, nitrogenados, antibióticos etc.). O crescimento das culturas nestas placas é feito adicionando-se meio mínimo sem fonte de carbono, e as culturas utilizam apenas a fonte de carbono fornecida em cada poço. Comparando-se o perfil de crescimento dos mutantes $\Delta f e c A 2$ e $\Delta f e c I 4$ com o de NA1000, pode-se ter indícios mais claros do papel fisiológico do fator sigma correspondente, se o crescimento em determinado substrato for impedido pela mutação.

Tendo em vista que vários genes induzidos em $\Delta f e c R 4$ (conforme observado em microarranjos de cDNA) possuem função de metabolismo ou biossíntese de compostos carbônicos, microplacas Biolog contendo diferentes compostos carbônicos foram testadas (modelos PM1 e PM2A). A figura 27 mostra uma representação gráfica do crescimento neste tipo de experimento, em que cada poço da placa possui uma curva de crescimento correspondente; desse modo, é possível determinar de modo rápido a presença ou ausência de crescimento em uma determinada fonte de carbono. As tabelas 8 e 9 mostram os perfis de crescimento de cada linhagem em cada placa após 24 horas de incubação.

Na placa PM1, houve crescimento de C. crescentus em 17 das 95 fontes de carbono listadas. Sempre que houve crescimento de NA1000, também houve dos mutantes; no entanto, cada linhagem só foi analisada uma vez neste tipo de placa. Portanto, nos casos em que há menor crescimento de pelo menos um dos mutantes (como em D-manose e D-xilose), isto não significa necessariamente um defeito de crescimento, podendo significar apenas uma variabilidade normal do experimento ou ainda um efeito decorrente dos critérios de categorização do nível de crescimento. Uma replicata é necessária para obter maior robustez nos resultados. 
Plate1

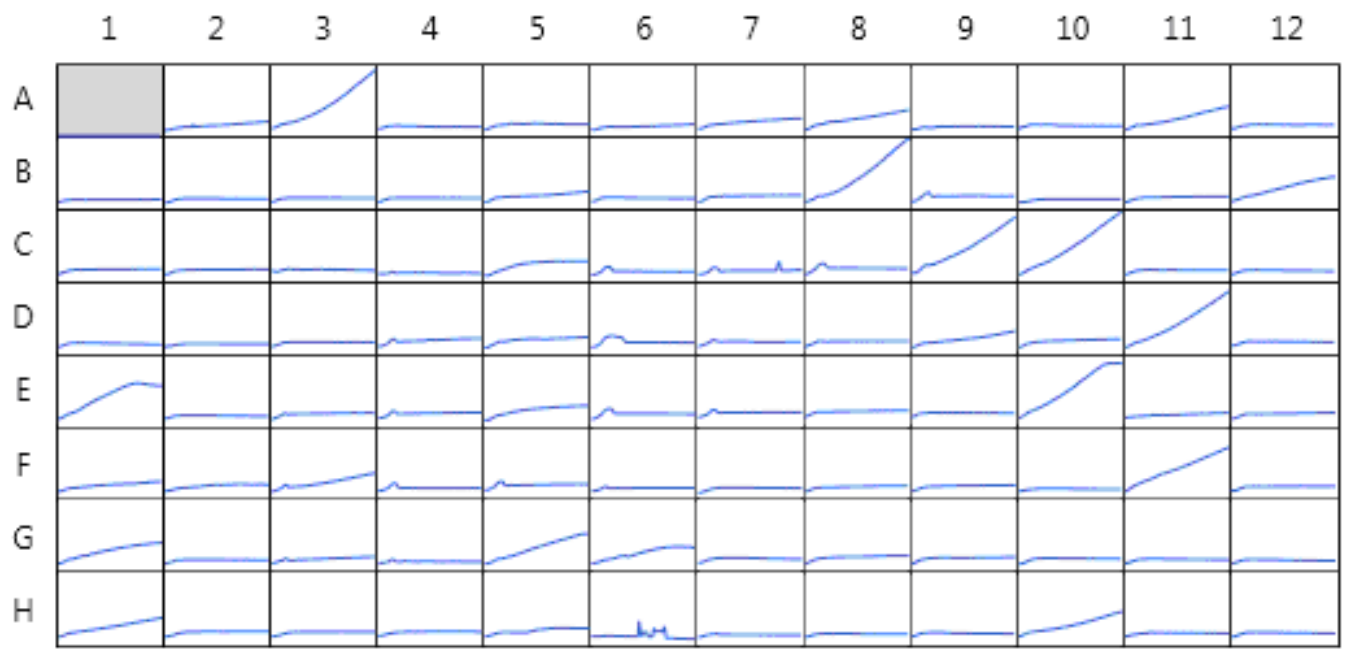

Figura 27 - Representação esquemática do perfil de crescimento observado em microplacas Biolog. As fontes de carbono presentes na placa são identificadas pelas coordenadas, e em cada uma delas pode ser observada a curva de crescimento correspondente obtida. O poço A1 corresponde ao controle negativo (sem cultura e sem fonte de carbono). Exemplo mostrando um experimento de crescimento de $\Delta$ fecI4 utilizando microplaca PM1. As curvas de crescimento foram obtidas pela medida da absorbância a $600 \mathrm{~nm}$ a cada 15 minutos no sistema Paradigm (Molecular Devices).

Já na placa PM2A, a análise de crescimento foi realizada em duplicata. Nesta placa, apenas cinco fontes de carbono permitiram crescimento de $C$. crescentus: $\alpha$-ciclodextrina, $\gamma$ ciclodextrina, dextrina, gentiobiose e ácido caproico. Dentre estas fontes, $\gamma$-ciclodextrina e ácido caproico se mostraram interessantes, tendo em vista que existe uma perceptível diminuição do nível de crescimento do mutante $\Delta$ fecI4 em relação a NA1000 (Tabela 9 e Fig. 28). Inclusive, no caso do ácido caproico, a $\mathrm{DO}_{600}$ final do mutante não chega sequer a 0,35 , que se considerou o corte para determinar se houve ou não crescimento. 
Tabela 8. Perfil de crescimento de $C$. crescentus em microplacas Biolog PM1. Os sinais indicam presença (+) ou ausência (-) de crescimento de cada linhagem no composto correspondente.,$+ \mathrm{DO}_{600}$ final entre 0,35 e 0,$7 ;++$, entre 0,7 e 1 ; e +++ , acima de 1 (sendo a $\mathrm{DO}_{600}$ inicial próxima a 0,15 ). A análise do crescimento foi realizada a partir de um experimento.

\begin{tabular}{|c|c|c|c|}
\hline Composto & $\begin{array}{l}\text { Crescimento } \\
\text { em NA1000 }\end{array}$ & $\begin{array}{c}\text { Crescimento } \\
\text { em } \Delta f e c I 4\end{array}$ & $\begin{array}{c}\text { Crescimento } \\
\text { em } \Delta f e c A 2\end{array}$ \\
\hline L-arabinose & - & - & - \\
\hline N-acetil-D-glicosamina & ++ & +++ & ++++ \\
\hline Ácido D-sacárico & - & - & - \\
\hline Ácido succínico & - & - & - \\
\hline D-galactose & - & - & - \\
\hline Ácido L-aspártico & - & - & - \\
\hline L-prolina & + & + & + \\
\hline D-alanina & - & - & - \\
\hline D-trealose & - & - & - \\
\hline D-manose & ++ & + & + \\
\hline Dulcitol & - & - & - \\
\hline D-serina & - & - & - \\
\hline D-sorbitol & - & - & - \\
\hline Glicerol & - & - & - \\
\hline L-fucose & - & - & - \\
\hline Ácido D-glucurônico & - & - & - \\
\hline Ácido D-glucônico & - & - & - \\
\hline D,L- $\alpha$-glicerol-fosfato & - & - & - \\
\hline D-xilose & +++ & +++ & ++ \\
\hline Ácido L-láctico & - & - & - \\
\hline Ácido fórmico & - & - & - \\
\hline D-manitol & - & - & - \\
\hline Ácido L-glutâmico & + & + & + \\
\hline D-glicose-6-fosfato & - & - & - \\
\hline Ácido D-galactônico- $\gamma$-lactona & - & - & - \\
\hline Ácido D,L-málico & - & - & - \\
\hline D-ribose & - & - & - \\
\hline Tween 20 & - & - & - \\
\hline
\end{tabular}


Tabela 8. Perfil de crescimento de C. crescentus em microplacas Biolog PM1. (Continuação)

\begin{tabular}{|c|c|c|c|}
\hline Composto & $\begin{array}{l}\text { Crescimento } \\
\text { em NA1000 }\end{array}$ & $\begin{array}{c}\text { Crescimento } \\
\text { em } \Delta f e c I 4\end{array}$ & $\begin{array}{c}\text { Crescimento } \\
\text { em } \Delta f e c A 2\end{array}$ \\
\hline L-ramnose & - & - & - \\
\hline D-frutose & - & - & - \\
\hline Ácido acético & - & - & - \\
\hline$\alpha$-D-glicose & +++ & +++ & +++ \\
\hline Maltose & +++ & +++ & +++ \\
\hline D-melibiose & - & - & - \\
\hline Timidina & - & - & - \\
\hline L-asparagina & - & - & - \\
\hline Ácido D-aspártico & - & - & - \\
\hline Ácido D-glucosamínico & - & - & - \\
\hline 1,2-propanodiol & - & - & - \\
\hline Tween 40 & - & - & - \\
\hline Ácido $\alpha$-ceto-glutárico & - & - & - \\
\hline Ácido $\alpha$-ceto-butírico & - & - & - \\
\hline$\alpha$-metil-D-galactosídeo & - & - & - \\
\hline$\alpha$-D-lactose & + & + & + \\
\hline Lactulose & - & - & - \\
\hline Sacarose & +++ & +++ & +++ \\
\hline Uridina & - & - & - \\
\hline L-glutamina & - & - & - \\
\hline Ácido M-tartárico & - & - & - \\
\hline D-glicose-1-fosfato & - & - & - \\
\hline D-frutose-6-fosfato & - & - & - \\
\hline Tween 80 & - & - & - \\
\hline $\begin{array}{c}\text { Ácido } \alpha \text {-hidroxiglutárico- } \gamma \text { - } \\
\text { lactona }\end{array}$ & - & - & - \\
\hline Ácido $\alpha$-hidroxibutírico & - & - & - \\
\hline$\beta$-metil-D-glicosídeo & - & - & - \\
\hline Adonitol & - & - & - \\
\hline
\end{tabular}


Tabela 8. Perfil de crescimento de C. crescentus em microplacas Biolog PM1. (Continuação)

\begin{tabular}{|c|c|c|c|}
\hline Composto & $\begin{array}{l}\text { Crescimento } \\
\text { em NA1000 }\end{array}$ & $\begin{array}{c}\text { Crescimento } \\
\text { em } \Delta f e c I 4\end{array}$ & $\begin{array}{c}\text { Crescimento } \\
\text { em } \Delta f e c A 2\end{array}$ \\
\hline Maltotriose & +++ & +++ & +++ \\
\hline 2-deoxiadenosina & - & - & - \\
\hline Adenosina & - & - & - \\
\hline Ácido glicil-L-aspártico & - & - & - \\
\hline Ácido cítrico & - & - & - \\
\hline M-inositol & + & + & ++ \\
\hline D-treonina & - & - & - \\
\hline Ácido fumárico & - & - & - \\
\hline Ácido bromo succínico & - & - & - \\
\hline Ácido propiônico & - & - & - \\
\hline Ácido múcico & - & - & - \\
\hline Ácido glicólico & - & - & - \\
\hline Ácido glioxílico & - & - & - \\
\hline D-celobiose & ++ & ++ & +++ \\
\hline Inosina & - & - & - \\
\hline Ácido glicil-L-glutâmico & + & + & + \\
\hline Ácido tricarbalílico & - & - & - \\
\hline L-serina & - & - & - \\
\hline L-treonina & - & - & - \\
\hline L-alanina & ++ & ++ & ++ \\
\hline L-alanil-glicina & + & + & + \\
\hline Ácido acetoacético & - & - & - \\
\hline $\mathrm{N}$-acetil- $\beta$-D-manosamina & - & - & - \\
\hline Monometil succinato & - & - & - \\
\hline Metil piruvato & - & - & - \\
\hline Ácido D-málico & - & - & - \\
\hline Ácido L-málico & - & - & - \\
\hline Glicil-L-prolina & + & + & + \\
\hline Ácido p-hidroxifenilacético & - & - & - \\
\hline
\end{tabular}

(Continua) 
Tabela 8. Perfil de crescimento de C. crescentus em microplacas Biolog PM1. (Continuação)

\begin{tabular}{c|c|c|c} 
Composto & $\begin{array}{c}\text { Crescimento } \\
\text { em NA1000 }\end{array}$ & $\begin{array}{c}\text { Crescimento } \\
\text { em } \Delta f e c I 4\end{array}$ & $\begin{array}{c}\text { Crescimento } \\
\text { em } \Delta f e c A 2\end{array}$ \\
\hline Ácido m-hidroxifenilacético & - & - & - \\
\hline Tiramina & - & - & - \\
\hline D-psicose & - & - & - \\
\hline L-lixose & - & - & - \\
\hline Glucuronamida & - & - & - \\
\hline Ácido pirúvico & - & - & - \\
\hline Ácido L-galactônico- $\gamma$-lactona & - & - & - \\
\hline Ácido D-galacturônico & + & + & ++ \\
\hline Feniletilamina & - & - & - \\
\hline 2-aminoetanol & - & - & (Conclusão) \\
\hline
\end{tabular}


Tabela 9. Perfil de crescimento de $C$. crescentus em microplacas Biolog PM2A. Os sinais indicam presença (+) ou ausência (-) de crescimento de cada linhagem no composto correspondente.,$+ \mathrm{DO}_{600}$ final entre 0,35 e 0,$7 ;++$, entre 0,7 e 1 ; e +++ , acima de 1 (sendo a $\mathrm{DO}_{600}$ inicial próxima a 0,15 ). A análise do crescimento foi realizada a partir de experimentos em duplicata, considerando-se a média entre as $\mathrm{DO}_{600}$ finais para cada linhagem.

\begin{tabular}{|c|c|c|}
\hline Composto & $\begin{array}{l}\text { Crescimento } \\
\text { em NA1000 }\end{array}$ & $\begin{array}{c}\text { Crescimento } \\
\text { em } \Delta f e c I 4\end{array}$ \\
\hline Condroitina sulfato $\mathrm{C}$ & - & - \\
\hline$\alpha$-ciclodextrina & + & + \\
\hline$\beta$-ciclodextrina & - & - \\
\hline$\gamma$-ciclodextrina & ++ & + \\
\hline Dextrina & + & + \\
\hline Gelatina & - & - \\
\hline Glicogênio & - & - \\
\hline Inulina & - & - \\
\hline Laminarina & - & - \\
\hline Manana & - & - \\
\hline Pectina & - & - \\
\hline N-acetil-D-galactosamina & - & - \\
\hline Ácido N-acetil-neuramínico & - & - \\
\hline$\beta$-D-alose & - & - \\
\hline Amigdalina & - & - \\
\hline D-arabinose & - & - \\
\hline D-arabitol & - & - \\
\hline L-arabitol & - & - \\
\hline Arbutina & - & - \\
\hline 2-deoxi-D-ribose & - & - \\
\hline 1-eritritol & - & - \\
\hline D-fucose & - & - \\
\hline $\begin{array}{c}\text { 3-0- } \beta \text {-D-galactopiranosil-D- } \\
\text { arabinose }\end{array}$ & - & - \\
\hline Gentiobiose & ++ & ++ \\
\hline L-glicose & - & - \\
\hline Lactitol & - & - \\
\hline
\end{tabular}


Tabela 9. Perfil de crescimento de $C$. crescentus em microplacas Biolog PM2A. (Continuação)

\begin{tabular}{|c|c|c|}
\hline Composto & $\begin{array}{l}\text { Crescimento } \\
\text { em NA1000 }\end{array}$ & $\begin{array}{c}\text { Crescimento } \\
\text { em } \Delta f e c I 4\end{array}$ \\
\hline D-melezitose & - & - \\
\hline Maltitol & - & - \\
\hline$\alpha$-metil-D-glicosídeo & - & - \\
\hline$\beta$-metil-D-galactosídeo & - & - \\
\hline 3-metil glicose & - & - \\
\hline $\begin{array}{l}\text { Ácido } \beta \text {-metil-D- } \\
\text { glucurônico }\end{array}$ & - & - \\
\hline$\alpha$-metil-D-manosídeo & - & - \\
\hline$\beta$-metil-D-xilosídeo & - & - \\
\hline Palatinose & - & - \\
\hline D-rafinose & - & - \\
\hline Salicina & - & - \\
\hline Sedoheptulosan & - & - \\
\hline L-sorbose & - & - \\
\hline Estaquiose & - & - \\
\hline D-tagatose & - & - \\
\hline Turanose & - & - \\
\hline Xilitol & - & - \\
\hline N-acetil-D-glucosaminitol & - & - \\
\hline Ácido $\gamma$-amino butírico & - & - \\
\hline Ácido $\delta$-amino valérico & - & - \\
\hline Ácido butírico & - & - \\
\hline Ácido cáprico & - & - \\
\hline Ácido caproico & + & - \\
\hline Ácido citracônico & - & - \\
\hline Ácido citramálico & - & - \\
\hline
\end{tabular}


Tabela 9. Perfil de crescimento de $C$. crescentus em microplacas Biolog PM2A. (Continuação)

\begin{tabular}{|c|c|c|}
\hline Composto & $\begin{array}{l}\text { Crescimento } \\
\text { em NA1000 }\end{array}$ & $\begin{array}{c}\text { Crescimento } \\
\text { em } \Delta f e c I 4\end{array}$ \\
\hline D-glucosamina & - & - \\
\hline Ácido 2-hidroxibenzóico & - & - \\
\hline Ácido 4-hidroxibenzóico & - & - \\
\hline Ácido $\beta$-hidroxibutírico & - & - \\
\hline Ácido $\gamma$--hidroxibutírico & - & - \\
\hline Ácido $\alpha$-ceto-valérico & - & - \\
\hline Ácido itacônico & - & - \\
\hline Ácido 5-ceto-D-glucônico & - & - \\
\hline Ácido D-láctico metil éster & - & - \\
\hline Ácido malônico & - & - \\
\hline Ácido melibiônico & - & - \\
\hline Ácido oxálico & - & - \\
\hline Ácido oxalomálico & - & - \\
\hline Ácido quínico & - & - \\
\hline D-ribono-1,4-lactona & - & - \\
\hline Ácido sebácico & - & - \\
\hline Ácido sórbico & - & - \\
\hline Ácido succinâmico & - & - \\
\hline Ácido D-tartárico & - & - \\
\hline Ácido L-tartárico & - & - \\
\hline Acetamida & - & - \\
\hline L-alaninamida & - & - \\
\hline Ácido N-acetil-L-glutâmico & - & - \\
\hline L-arginina & - & - \\
\hline Glicina & - & - \\
\hline L-histidina & - & - \\
\hline
\end{tabular}


Tabela 9. Perfil de crescimento de C. crescentus em microplacas Biolog PM2A. (Continuação)

\begin{tabular}{|c|c|c|}
\hline Composto & $\begin{array}{l}\text { Crescimento } \\
\text { em NA1000 }\end{array}$ & $\begin{array}{c}\text { Crescimento } \\
\text { em } \Delta f e c I 4\end{array}$ \\
\hline L-homoserina & - & - \\
\hline Hidroxi-L-prolina & - & - \\
\hline L-isoleucina & - & - \\
\hline L-leucina & - & - \\
\hline L-lisina & - & - \\
\hline L-metionina & - & - \\
\hline L-ornitina & - & - \\
\hline L-fenilalanina & - & - \\
\hline Ácido L-piroglutâmico & - & - \\
\hline L-valina & - & - \\
\hline D,L-carnitina & - & - \\
\hline Sec-butilamina & - & - \\
\hline D,L-octopamina & - & - \\
\hline Putrescina & - & - \\
\hline Dihidroxiacetona & - & - \\
\hline 2,3-butanodiol & - & - \\
\hline 2,3-butanona & - & - \\
\hline 3-hidroxi 2-butanona & - & - \\
\hline
\end{tabular}




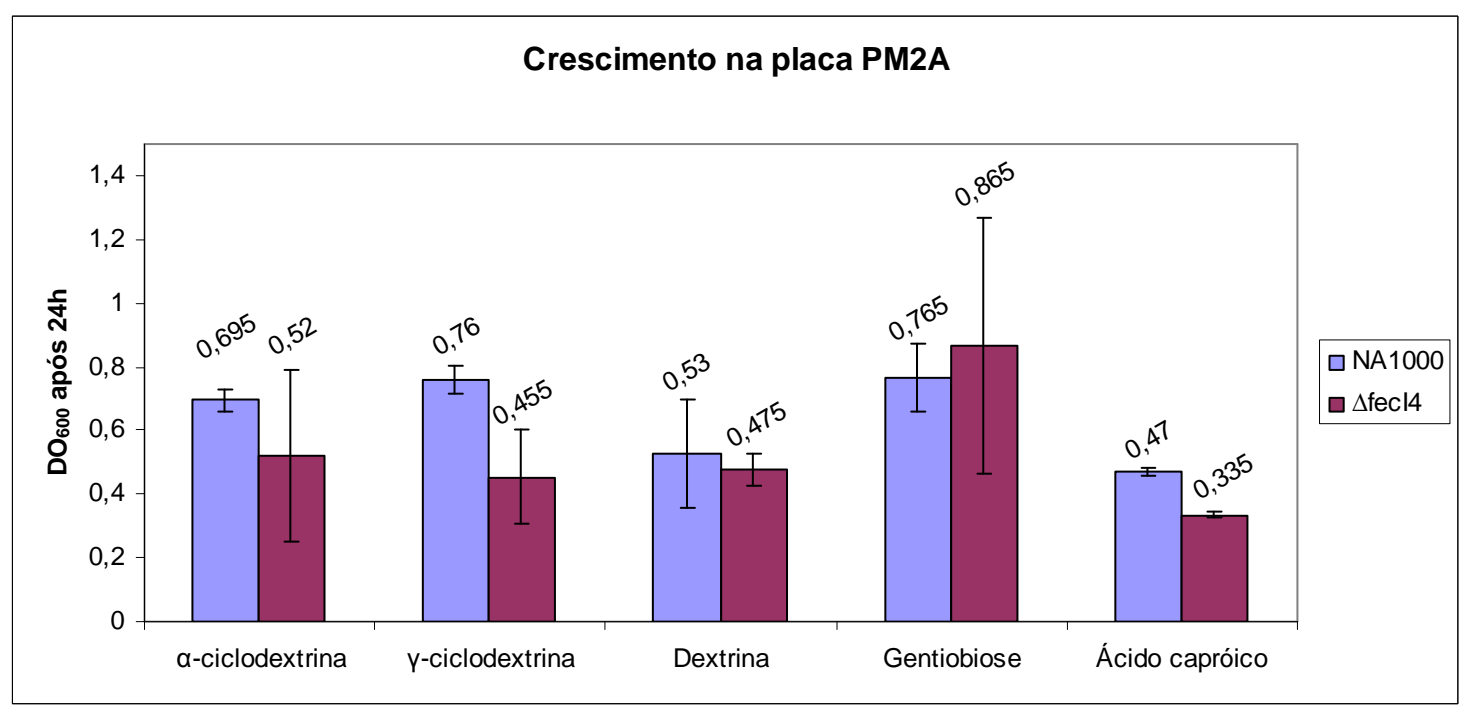

Figura 28 - Análise do crescimento de NA1000 e $\Delta f e c I 4$ em microarranjos fenotípicos. No gráfico, estão mostradas as fontes de carbono presentes na microplaca PM2A (Biolog) que permitiram crescimento de NA1000. A média da $\mathrm{DO}_{600}$ após 24 horas de incubação na microplaca, obtida por dois experimentos distintos, é indicada acima de cada barra. O desvio padrão aparece indicado pelas barras pretas.

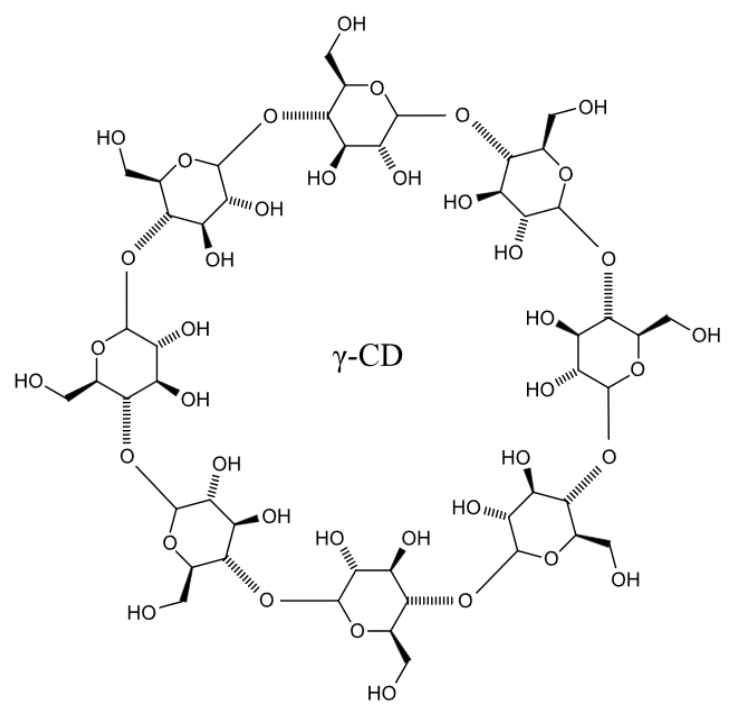

(A)<smiles>CCCCCC(=O)O</smiles>

(B)

Figura 29 - Estrutura de compostos carbônicos possivelmente envolvidos na via regulatória de FecI4. (A), $\gamma$-ciclodextrina; (B), ácido capróico. 
Estes resultados indicam que estas duas fontes de carbono podem estar envolvidas na regulação de vias metabólicas pelo fator sigma FecI4. Não é evidente a relação entre os dois compostos, pois estes possuem estruturas bem distintas (Fig. 29). Ciclodextrinas são oligossacarídeos cíclicos oriundos da degradação do amido (SZEJTLI, 1998). As ciclodextrinas têm a capacidade de se complexar com uma grande variedade de compostos orgânicos, sendo utilizadas na agricultura para formar corpos de inclusão com vários pesticidas (SZEJTLI, 1998). Inclusive, a habilidade de algumas bactérias em degradar ciclodextrina acaba sendo um problema durante a aplicação de pesticidas (OROS et al., 1990). Dentre os monômeros de ciclodextrinas, a $\gamma$-ciclodextrina é considerada a mais biodegradável, pois sua estrutura é menos rígida e mais propensa a ataque enzimático (OROS et al., 1990). O ácido caproico é um ácido carboxílico derivado do hexano e ocorre naturalmente nas gorduras do leite e no óleo de coco, sendo empregado na indústria farmacêutica e na fabricação de ésteres para aromatizantes artificiais (BUDAVARI; O'NEIL; HECKELMAN, 1989).

A abordagem por microarranjos fenotípicos não foi capaz de fornecer mais informações sobre possíveis alvos de transporte de FecA2 (e, por extensão, de alvos de regulação do fator sigma FecI2). Ensaios com placas adicionais são necessários para um maior entendimento da via regulatória de FecI2. No entanto, os ensaios forneceram informações interessantes a respeito da regulação por FecI4, que pode estar envolvida com a utilização de $\gamma$-ciclodextrina ou ácido caproico.

Os microarranjos fenotípicos foram úteis não só para o foco deste trabalho, mas também para identificação das fontes de carbono utilizadas por $C$. crescentus, o que sem dúvida acrescenta informações sobre a capacidade metabólica desta bactéria. O próximo passo neste trabalho foi investigar, por ensaios de crescimento em maior escala, o efeito destes compostos no crescimento de $\Delta f e c I 4$, para verificar se o resultado obtido nas microplacas Biolog se mantinham. Isto foi realizado para o composto $\gamma$-ciclodextrina.

As curvas de crescimento das linhagens NA1000 e $\Delta f e c I 4$ foram analisadas após substituição do meio mínimo M2 original das culturas (contendo glicose) por M2 contendo $\gamma$ ciclodextrina como única fonte de carbono. A figura 30 mostra que o crescimento de ambas as linhagens foi similar no meio mínimo original; já em M2 contendo $\gamma$-ciclodextrina, contudo, a taxa de crescimento foi maior na linhagem parental do que em $\Delta f e c I 4$. Este resultado indica que FecI4 pode estar envolvido com a utilização de $\gamma$-ciclodextrina como fonte de carbono em C. crescentus. 


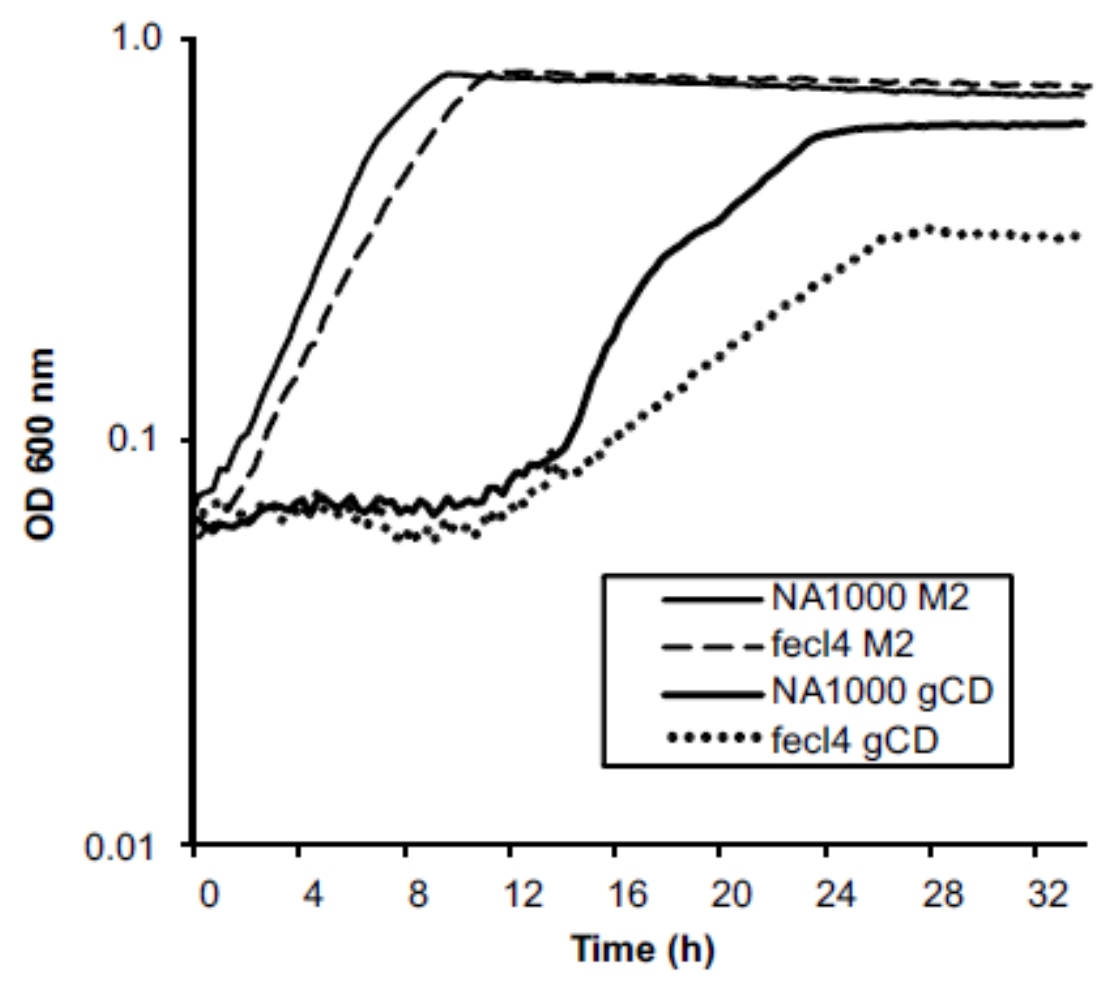

Figura 30 - Curvas de crescimento em $\boldsymbol{\gamma}$-ciclodextrina. Culturas de NA1000 e de $\Delta f e c I 4$ em meio mínimo M2 tiveram o meio substituído por M2 contendo $\gamma$-ciclodextrina $(\mathrm{gCD}, 0,1 \%)$ como única fonte de carbono. As medidas da densidade óptica a $600 \mathrm{~nm}$ foram realizadas a cada 15 minutos. Os dados correspondem a um experimento.

Há relatos de utilização de $\gamma$-ciclodextrina por micro-organismos, como Bacillus subtilis (KAMIONKA; DAHL, 2001). Nesta bactéria, a proteína CycB provavelmente pertence a um sistema de transporte do tipo $\mathrm{ABC}$, ligando-se a $\alpha$-, $\beta$ - e $\gamma$-ciclodextrina e exibindo alta similaridade com proteínas ligantes de maltodextrina, como MalE de E. coli (SHARFF; RODSETH; QUIOCHO, 1993), MalX de S. pneumonia (NIETO; ESPINOSA; PUYET, 1997), MalE de B. subtilis (SCHONERT et al., 2006) e MyaA de Thermotoga maritima (LIEBL; STEMPLINGER; RUILE, 1997). Outra proteína similar está presente em Klebsiella oxytoca, a proteína CymE, que, juntamente com MalE de E. coli, é capaz de ligação a ciclodextrina; no entanto, esta molécula não é capaz de promover o crescimento destes dois micro-organismos, ao contrário de B. subtilis (SHARFF; RODSETH; QUIOCHO, 
1993). Não foram encontrados ortólogos de CycB no genoma de C. crescentus (NIERMAN et al., 2001); proteínas ligantes de ciclodextrinas ainda não foram descobertas nesta bactéria.

Espécies bacterianas que vivem em ambientes oligotróficos ou com grandes variações nutricionais, como solo e água, são particularmente ricas em fatores sigma de função extracitoplasmática e em receptores dependentes de TonB (BRAUN; MAHREN; OGIERMAN, 2003). Isto indica que outros nutrientes escassos além do ferro podem ser tomados por sistemas de transporte ativo através da membrana. Estes sistemas podem não apenas realizar o transporte destas substâncias, como também efetuar a sinalização e transdução do sinal através da membrana, culminando na ativação dos fatores sigma associados. C. crescentus pode seguir este exemplo, na medida em que vive em ambientes aquáticos oligotróficos e possui uma alta afinidade na tomada de nutrientes do meio, o que se reflete na riqueza em receptores de membrana dependentes de TonB (NIERMAN et al., 2001). De fato, dois receptores dependentes de TonB de C. crescentus foram caracterizados como transportadores de compostos orgânicos não relacionados ao metabolismo de ferro, quais sejam, maltodextrinas e $\mathrm{N}$-acetilglicosamina (EISENBEIS et al., 2008; NEUGEBAUER et al., 2005). Outros dez genes codificando este tipo de receptor são induzidos em carência de carbono em C. crescentus (BRITOS et al., 2011). É provável, portanto, que esta classe de receptores seja utilizada para o transporte específico de uma gama maior de moléculas do que se acreditava anteriormente.

Estudos sobre o perfil de transcrição global de C. crescentus em limitação de carbono indicam que a estratégia desta bactéria é diferente de outras bactérias, não oligotróficas. Quando $C$. crescentus se encontra nesta condição, há indução de genes envolvidos na aquisição de carbono de fontes derivadas de estruturas vegetais, como lignina e terpenos, que são relativamente abundantes em ambientes aquáticos oligotróficos. Este padrão de expressão gênica difere daquele apresentado por organismos que habitam ambientes ricos em nutrientes, quando expostos à mesma condição: nestes, os genes induzidos estão relacionados à utilização de carbono proveniente de outras fontes, como açúcares simples, amido e ácidos graxos (ENGLAND et al., 2010). Argumenta-se que a presença de C. crescentus em ambientes aquáticos é importante para a ciclagem de carbono nestes habitats (BOUTTE; CROSSON, 2013). Estas observações sugerem que as bactérias utilizam estratégias_específicas para utilização dos recursos nutricionais disponíveis, através de redes de expressão gênica adaptadas ao seu ambiente natural.

Apesar de não ter fornecido respostas definitivas, este trabalho forneceu indícios do sinal a que o fator sigma FecI4 responde. Ao contrário do inicialmente esperado, este fator 
sigma não parece possuir papel na aquisição de ferro por C. crescentus. Neste trabalho, foram coletados dados substanciais para afirmar que a via regulatória de FecI4 é mediada por algum outro fator em vez de compostos férricos; aparentemente, este fator seria uma fonte de carbono alternativa. Em relação ao fator sigma FecI2, apesar de os resultados obtidos não terem fornecido informações concretas, é possível afirmar que este fator sigma também não estaria envolvido com a homeostase de ferro em $C$. crescentus, já que esta possibilidade foi avaliada de diversas formas (avaliação da expressão de promotores, da relação com Fur, da utilização de compostos férricos inorgânicos e sideróforos, análise do regulon, microarranjos fenotípicos etc.). 


\section{CONCLUSÕES}

Os promotores analisados não se mostraram responsivos à disponibilidade de compostos férricos no meio, nem se mostraram regulados pela proteína Fur. A fusão transcricional PtonB2/lacZ apresenta atividade extremamente baixa em NA1000, mas esta atividade aumenta no mutante para o antissigma FecR2, indicando que o fator sigma FecI2 participa da via regulatória que coordena a atividade do promotor PtonB2. Este não é o caso para PtonB4, uma vez que sua expressão não se mostrou aumentada no mutante para o antissigma FecR4. Estabeleceu-se que os fatores sigma FecI2 e FecI4 não estão sujeitos a autorregulação. Ensaios fenotípicos mostraram que o crescimento das linhagens $\Delta f e c R 2$, $\Delta f e c R 4, \Delta f e c A 2$ e $\Delta f e c I 4$ é similar ao de NA1000, tanto em meio PYE quanto em meio mínimo M2 suplementado com diferentes fontes de ferro, e todos os mutantes são afetados por 2,2'-dipiridil de modo similar à linhagem parental NA1000. As linhagens NA1000, $\Delta f e c R 2$ e $\Delta f e c R 4$ também apresentaram níveis semelhantes de sensibilidade a peróxido de hidrogênio, indicando que a taxa de reação de Fenton e a resposta a estresse oxidativo não estão alteradas em razão das mutações.

Análises de microarranjos de DNA evidenciaram que o fator sigma FecI2 tem regulação bem restrita, apresentando apenas um gene alvo, que é o gene $f e c A 2$, codificando o receptor dependente de TonB do sistema FEC2. Já o fator sigma FecI4 aparenta ter uma resposta mais ampla, relacionada ao metabolismo e biossíntese de compostos carbônicos. Seis genes tiveram sua expressão maior em $\Delta f e c R 4$ validada por qRT-PCR. Estes genes puderam gerar um consenso de promotor reconhecido pelo fator sigma FecI4.

Microarranjos fenotípicos realizados em placas Biolog forneceram informações ricas sobre os substratos que $C$. crescentus é capaz de utilizar como fontes de carbono. No entanto, o perfil de crescimento do mutante $\triangle f e c A 2$ nas fontes estudadas foi semelhante ao da linhagem parental. Duas dessas fontes, porém, se mostraram interessantes para este estudo $(\gamma$ ciclodextrina e ácido caproico), nas quais o crescimento de $\Delta f e c I 4$ foi menor comparado com o da linhagem parental. Este efeito foi observado também em um ensaio em maior escala utilizando meio mínimo com $\gamma$-ciclodextrina como única fonte de carbono. Estes dados geraram um melhor indicativo dos alvos da via regulatória do fator sigma FecI4.

Em conjunto, os resultados evidenciam que o fator sigma FecI4 possui uma função não relacionada à homeostase de ferro em $C$. crescentus, o que foge à regra normalmente obedecida por fatores sigma do tipo FEC. FecI4 parece estar envolvido com a utilização de 
fontes alternativas de carbono; mais estudos são necessários, no entanto, para estabelecer se há outras fontes cuja via de degradação seja dependente de FecI4. Ainda, detalhes específicos da utilização de $\gamma$-ciclodextrina ou ácido caproico por $C$. crescentus não são conhecidos até o momento, assim como outros fatores possivelmente envolvidos com sua regulação. Não obstante, este trabalho mostrou-se importante para ressaltar a presença, em C. crescentus, de um fator sigma da família FecI que não está envolvido com a homeostase de ferro. 


\section{REFERÊNCIAS $^{1}$}

ANDREWS, S. C.; ROBINSON, A. K.; RODRIGUEZ-QUINONES, F. Bacterial iron homeostasis. FEMS Microbiol. Rev., v. 27, p. 215-237, 2003.

ANGERER, A.; ENZ, S.; OCHS, M.; BRAUN, V. Transcriptional regulation of ferric citrate transport in Escherichia coli K-12. Fecl belongs to a new subfamily of sigma 70-type factors that respond to extracytoplasmic stimuli. Mol. Microbiol., v. 18, p. 163-174, 1995.

BAILEY, T. L.; BODEN, M.; BUSKE, F. A.; FRITH, M.; GRANT, C. E.; CLEMENTI, L.; REN, J.; LI, W. W.; NOBLE, W. S. MEME SUITE: tools for motif discovery and searching. Nucleic Acids Res., v. 37, p. W202-208, 2009.

BIVILLE, F.; CWERMAN, H.; LETOFFE, S.; ROSSI, M. S.; DROUET, V.; GHIGO, J. M.; WANDERSMAN, C. Haemophore-mediated signalling in Serratia marcescens: a new mode of regulation for an extra cytoplasmic function (ECF) sigma factor involved in haem acquisition. Mol. Microbiol., v. 53, p. 1267-1277, 2004.

BOUTTE, C. C.; CROSSON, S. Bacterial lifestyle shapes stringent response activation. Trends Microbiol., v. 21, p. 174-180, 2013.

BRAUN, V. Surface signaling: novel transcription initiation mechanism starting from the cell surface. Arch. Microbiol., v. 167, p. 325-331, 1997.

BRAUN, V.; KILLMANN, H. Bacterial solutions to the iron-supply problem. Trends Biochem. Sci., v. 24, p. 104-109, 1999.

BRAUN, V.; MAHREN, S.; OGIERMAN, M. Regulation of the FecI-type ECF sigma factor by transmembrane signalling. Curr. Opin. Microbiol., v. 6, p. 173-180, 2003.

BRITOS, L.; ABELIUK, E.; TAVERNER, T.; LIPTON, M.; MCADAMS, H.; SHAPIRO, L. Regulatory response to carbon starvation in Caulobacter crescentus. PLoS One, v. 6, p. e18179, 2011.

BROWNING, D. F.; BUSBY, S. J. The regulation of bacterial transcription initiation. Nat. Rev. Microbiol., v. 2, p. 57-65, 2004.

BUDAVARI, S.; O'NEIL, M. J.; HECKELMAN, P. E. The Merck index: an encyclopedia of chemicals, drugs, and biologicals. Rahway, NJ: Merck, 1989.

CHOMCZYNSKI, P.; SACCHI, N. Single-step method of RNA isolation by acid guanidinium thiocyanate-phenol-chloroform extraction. Anal. Biochem., v. 162, p. 156-159, 1987.

CROSA, J. H.; WALSH, C. T. Genetics and assembly line enzymology of siderophore biosynthesis in bacteria. Microbiol. Mol. Biol. Rev., v. 66, p. 223-249, 2002.

\footnotetext{
${ }^{1}$ De acordo com:

ASSOCIAÇÃO BRASILEIRA DE NORMAS TÉCNICAS. NBR 6023: informação e documentação:

referências: elaboração. Rio de Janeiro, 2002.
} 
CURTIS, P. D.; BRUN, Y. V. Identification of essential alphaproteobacterial genes reveals operational variability in conserved developmental and cell cycle systems. Mol. Microbiol., v. 93, p. 713-735, 2014.

DA SILVA NETO, J. F.; BRAZ, V. S.; ITALIANI, V. C.; MARQUES, M. V. Fur controls iron homeostasis and oxidative stress defense in the oligotrophic alpha-proteobacterium Caulobacter crescentus. Nucleic Acids Res., v. 37, p. 4812-4825, 2009.

DA SILVA NETO, J. F.; LOURENÇO, R. F.; MARQUES, M. V. Global transcriptional response of Caulobacter crescentus to iron availability. BMC Genomics, v. 14, p. 549, 2013.

DAVIS, B. M.; WALDOR, M. K. Establishing polar identity in gram-negative rods. Curr. Opin. Microbiol., v. 16, p. 752-759, 2013.

DECKER, K. B.; HINTON, D. M. Transcription regulation at the core: similarities among bacterial, archaeal, and eukaryotic RNA polymerases. Annu. Rev. Microbiol., v. 67, p. 113139, 2013.

EISENBEIS, S.; LOHMILLER, S.; VALDEBENITO, M.; LEICHT, S.; BRAUN, V. NagAdependent uptake of $\mathrm{N}$-acetyl-glucosamine and $\mathrm{N}$-acetyl-chitin oligosaccharides across the outer membrane of Caulobacter crescentus. J. Bacteriol., v. 190, p. 5230-5238, 2008.

ELY, B. Genetics of Caulobacter crescentus. Methods Enzymol., v. 204, p. 372-384, 1991.

ELY, B.; SCOTT, L. E. Correction of the Caulobacter crescentus NA1000 genome annotation. PLoS One, v. 9, p. e91668, 2014.

ENGLAND, J. C.; PERCHUK, B. S.; LAUB, M. T.; GOBER, J. W. Global regulation of gene expression and cell differentiation in Caulobacter crescentus in response to nutrient availability. J. Bacteriol., v. 192, p. 819-833, 2010.

ENZ, S.; MAHREN, S.; STROEHER, U. H.; BRAUN, V. Surface signaling in ferric citrate transport gene induction: interaction of the FecA, FecR, and FecI regulatory proteins. J. Bacteriol., v. 182, p. 637-646, 2000.

EVINGER, M.; AGABIAN, N. Envelope-associated nucleoid from Caulobacter crescentus stalked and swarmer cells. J. Bacteriol., v. 132, p. 294-301, 1977.

FIGGE, R. M.; GOBER, J. W. Cell shape, division and development: the 2002 American Society for Microbiology (ASM) conference on prokaryotic development. Mol. Microbiol., v. 47, p. 1475-1483, 2003.

FRANCEZ-CHARLOT, A.; FRUNZKE, J.; REICHEN, C.; EBNETER, J. Z.; GOURION, B.; VORHOLT, J. A. Sigma factor mimicry involved in regulation of general stress response. Proc. Natl. Acad. Sci. USA, v. 106, p. 3467-3472, 2009.

FRANGIPANI, E.; SLAVEYKOVA, V. I.; REIMMANN, C.; HAAS, D. Adaptation of aerobically growing Pseudomonas aeruginosa to copper starvation. J. Bacteriol., v. 190, p. 6706-6717, 2008. 
GALHARDO, R. S.; ROCHA, R. P.; MARQUES, M. V.; MENCK, C. F. An SOS-regulated operon involved in damage-inducible mutagenesis in Caulobacter crescentus. Nucleic Acids Res., v. 33, p. 2603-2614, 2005.

GOBER, J. W.; SHAPIRO, L. A developmentally regulated Caulobacter flagellar promoter is activated by 3' enhancer and IHF binding elements. Mol. Biol. Cell, v. 3, p. 913-926, 1992.

GOLDBERG, M. B.; BARZU, O.; PARSOT, C.; SANSONETTI, P. J. Unipolar localization and ATPase activity of IcsA, a Shigella flexneri protein involved in intracellular movement. Infect. Agents Dis., v. 2, p. 210-211, 1993.

GOLEY, E. D.; INIESTA, A. A.; SHAPIRO, L. Cell cycle regulation in Caulobacter: location, location, location. J. Cell Sci., v. 120, p. 3501-3507, 2007.

GONIN, M.; QUARDOKUS, E. M.; O'DONNOL, D.; MADDOCK, J.; BRUN, Y. V. Regulation of stalk elongation by phosphate in Caulobacter crescentus. J. Bacteriol., v. 182, p. 337-347, 2000.

GUERINOT, M. L. Microbial iron transport. Annu. Rev. Microbiol., v. 48, p. 743-772, 1994.

HALLEZ, R.; BELLEFONTAINE, A. F.; LETESSON, J. J.; DE BOLLE, X. Morphological and functional asymmetry in alpha-proteobacteria. Trends Microbiol., v. 12, p. 361-365, 2004.

HANAHAN, D. Studies on transformation of Escherichia coli with plasmids. J. Mol. Biol., v. 166, p. 557-580, 1983.

HANTKE, K. Iron and metal regulation in bacteria. Curr. Opin. Microbiol., v. 4, p. 172177, 2001.

HANTKE, K.; BRAUN, V. The art of keeping low and high iron concentrations in balance. In: STORZ, G.; HENGGE-ARONIS, R. (Ed.). Bacterial stress responses. Washington, D. C.: American Society for Microbiology, 2000. p. 275-288.

HELMANN, J. D. The extracytoplasmic function (ECF) sigma factors. Adv. Microb. Physiol., v. 46, p. 47-110, 2002.

HIDER, R. C.; KONG, X. Chemistry and biology of siderophores. Nat. Prod. Rep., v. 27, p. 637-657, 2010.

HOLTZENDORFF, J.; HUNG, D.; BRENDE, P.; REISENAUER, A.; VIOLLIER, P. H.; MCADAMS, H. H.; SHAPIRO, L. Oscillating global regulators control the genetic circuit driving a bacterial cell cycle. Science, v. 304, p. 983-987, 2004.

ITALIANI, V. C.; DA SILVA NETO, J. F.; BRAZ, V. S.; MARQUES, M. V. Regulation of catalase-peroxidase KatG is OxyR dependent and Fur independent in Caulobacter crescentus. J. Bacteriol., v. 193, p. 1734-1744, 2011. 
JENAL, U. Signal transduction mechanisms in Caulobacter crescentus development and cell cycle control. FEMS Microbiol. Rev., v. 24, p. 177-191, 2000.

JENAL, U.; FUCHS, T. An essential protease involved in bacterial cell-cycle control. EMBO J., v. 17, p. 5658-5669, 1998.

JUDD, E. M.; RYAN, K. R.; MOERNER, W. E.; SHAPIRO, L.; MCADAMS, H. H. Fluorescence bleaching reveals asymmetric compartment formation prior to cell division in Caulobacter. Proc. Natl. Acad. Sci. USA, v. 100, p. 8235-8240, 2003.

JUNG, K.; FRIED, L.; BEHR, S.; HEERMANN, R. Histidine kinases and response regulators in networks. Curr. Opin. Microbiol., v. 15, p. 118-124, 2012.

KAMIONKA, A.; DAHL, M. K. Bacillus subtilis contains a cyclodextrin-binding protein which is part of a putative ABC-transporter. FEMS Microbiol. Lett., v. 204, p. 55-60, 2001.

KIEKEBUSCH, D.; THANBICHLER, M. Spatiotemporal organization of microbial cells by protein concentration gradients. Trends Microbiol., v. 22, p. 65-73, 2014.

KIRKPATRICK, C. L.; VIOLLIER, P. H. Decoding Caulobacter development. FEMS Microbiol. Rev., v. 36, p. 193-205, 2012.

KOEBNIK, R. TonB-dependent trans-envelope signalling: the exception or the rule? Trends Microbiol., v. 13, p. 343-347, 2005.

KOHLER, C.; LOURENÇO, R. F.; AVELAR, G. M.; GOMES, S. L. Extracytoplasmic function (ECF) sigma factor sigmaF is involved in Caulobacter crescentus response to heavy metal stress. BMC Microbiol., v. 12, p. 210, 2012.

KOSTER, W. ABC transporter-mediated uptake of iron, siderophores, heme and vitamin B12. Res. Microbiol., v. 152, p. 291-301, 2001.

LALOUX, G.; JACOBS-WAGNER, C. How do bacteria localize proteins to the cell pole? J. Cell Sci., v. 127, p. 11-19, 2014.

LANDT, S. G.; ABELIUK, E.; MCGRATH, P. T.; LESLEY, J. A.; MCADAMS, H. H.; SHAPIRO, L. Small non-coding RNAs in Caulobacter crescentus. Mol. Microbiol., v. 68, p. 600-614, 2008.

LARKIN, M. A.; BLACKSHIELDS, G.; BROWN, N. P.; CHENNA, R.; MCGETTIGAN, P. A.; MCWILLIAM, H.; VALENTIN, F.; WALLACE, I. M.; WILM, A.; LOPEZ, R.; THOMPSON, J. D.; GIBSON, T. J.; HIGGINS, D. G. Clustal W and Clustal X version 2.0. Bioinformatics, v. 23, p. 2947-2948, 2007.

LIEBL, W.; STEMPLINGER, I.; RUILE, P. Properties and gene structure of the Thermotoga maritima alpha-amylase AmyA, a putative lipoprotein of a hyperthermophilic bacterium. $\mathbf{J}$. Bacteriol., v. 179, p. 941-948, 1997. 
LIVAK, K. J.; SCHMITTGEN, T. D. Analysis of relative gene expression data using realtime quantitative PCR and the 2(-Delta Delta C(T)) Method. Methods, v. 25, p. 402-408, 2001.

LOH, J. T.; HO, S. C.; DE FEIJTER, A. W.; WANG, J. L.; SCHINDLER, M. Carbohydrate binding activities of Bradyrhizobium japonicum: unipolar localization of the lectin BJ38 on the bacterial cell surface. Proc. Natl. Acad. Sci. USA, v. 90, p. 3033-3037, 1993.

LONETTO, M. A.; BROWN, K. L.; RUDD, K. E.; BUTTNER, M. J. Analysis of the Streptomyces coelicolor sigE gene reveals the existence of a subfamily of eubacterial RNA polymerase sigma factors involved in the regulation of extracytoplasmic functions. Proc. Natl. Acad. Sci. USA, v. 91, p. 7573-7577, 1994.

LOURENÇO, R. F.; KOHLER, C.; GOMES, S. L. A two-component system, an anti-sigma factor and two paralogous ECF sigma factors are involved in the control of general stress response in Caulobacter crescentus. Mol. Microbiol., v. 80, p. 1598-1612, 2011.

MAGNUSSON, L. U.; FAREWELL, A.; NYSTROM, T. ppGpp: a global regulator in Escherichia coli. Trends Microbiol., v. 13, p. 236-242, 2005.

MAHREN, S.; ENZ, S.; BRAUN, V. Functional interaction of region 4 of the extracytoplasmic function sigma factor FecI with the cytoplasmic portion of the FecR transmembrane protein of the Escherichia coli ferric citrate transport system. J. Bacteriol., v. 184, p. 3704-3711, 2002.

MASSE, E.; GOTTESMAN, S. A small RNA regulates the expression of genes involved in iron metabolism in Escherichia coli. Proc. Natl. Acad. Sci. USA, v. 99, p. 4620-4625, 2002.

METTRICK, K. A.; LAMONT, I. L. Different roles for anti-sigma factors in siderophore signalling pathways of Pseudomonas aeruginosa. Mol. Microbiol., v. 74, p. 1257-1271, 2009.

MILLER, J. H. Experiments in molecular genetics. Cold Spring Harbor: Cold Spring Harbor Laboratory Press, 1972.

MISSIAKAS, D.; RAINA, S. The extracytoplasmic function sigma factors: role and regulation. Mol. Microbiol., v. 28, p. 1059-1066, 1998.

NEUGEBAUER, H.; HERRMANN, C.; KAMMER, W.; SCHWARZ, G.; NORDHEIM, A.; BRAUN, V. ExbBD-dependent transport of maltodextrins through the novel MalA protein across the outer membrane of Caulobacter crescentus. J. Bacteriol., v. 187, p. 8300-8311, 2005.

NIERMAN, W. C.; FELDBLYUM, T. V.; LAUB, M. T.; PAULSEN, I. T.; NELSON, K. E.; EISEN, J. A.; HEIDELBERG, J. F.; ALLEY, M. R.; OHTA, N.; MADDOCK, J. R.; POTOCKA, I.; NELSON, W. C.; NEWTON, A.; STEPHENS, C.; PHADKE, N. D.; ELY, B.; DEBOY, R. T.; DODSON, R. J.; DURKIN, A. S.; GWINN, M. L.; HAFT, D. H.; KOLONAY, J. F.; SMIT, J.; CRAVEN, M. B.; KHOURI, H.; SHETTY, J.; BERRY, K.; UTTERBACK, T.; TRAN, K.; WOLF, A.; VAMATHEVAN, J.; ERMOLAEVA, M.; WHITE, O.; SALZBERG, S. L.; VENTER, J. C.; SHAPIRO, L.; FRASER, C. M. Complete 
genome sequence of Caulobacter crescentus. Proc. Natl. Acad. Sci. USA, v. 98, p. 41364141, 2001.

NIETO, C.; ESPINOSA, M.; PUYET, A. The maltose/maltodextrin regulon of Streptococcus pneumoniae. Differential promoter regulation by the transcriptional repressor MalR. J. Biol. Chem., v. 272, p. 30860-30865, 1997.

OCHS, M.; VEITINGER, S.; KIM, I.; WELZ, D.; ANGERER, A.; BRAUN, V. Regulation of citrate-dependent iron transport of Escherichia coli: $f e c R$ is required for transcription activation by FecI. Mol. Microbiol., v. 15, p. 119-132, 1995.

OCHSNER, U. A.; JOHNSON, Z.; LAMONT, I. L.; CUNLIFFE, H. E.; VASIL, M. L. Exotoxin A production in Pseudomonas aeruginosa requires the iron-regulated $p v d S$ gene encoding an alternative sigma factor. Mol. Microbiol., v. 21, p. 1019-1028, 1996.

OROS, G.; CSERHÁTI, T.; FENYVESI, E.; SZEJTLI, J. Microbial decomposition of some cyclodextrin derivatives by bacteria associated with plants. Intl. Biodeter. Biodegr., v. 26, p. 33-42, 1990.

PARK, S. J.; GUNSALUS, R. P. Oxygen, iron, carbon, and superoxide control of the fumarase fumA and fumC genes of Escherichia coli: role of the arcA, fnr, and soxR gene products. J. Bacteriol., v. 177, p. 6255-6262, 1995.

PORCHERON, G.; GARENAUX, A.; PROULX, J.; SABRI, M.; DOZOIS, C. M. Iron, copper, zinc, and manganese transport and regulation in pathogenic Enterobacteria: correlations between strains, site of infection and the relative importance of the different metal transport systems for virulence. Front. Cell Infect. Microbiol., v. 3, p. 90, 2013.

PURCELL, E. B.; BOUTTE, C. C.; CROSSON, S. Two-component signaling systems and cell cycle control in Caulobacter crescentus. Adv. Exp. Med. Biol., v. 631, p. 122-130, 2008.

RATlEDGE, C.; DOVER, L. G. Iron metabolism in pathogenic bacteria. Annu. Rev. Microbiol., v. 54, p. 881-941, 2000.

RODIONOV, D. A.; GELFAND, M. S.; TODD, J. D.; CURSON, A. R.; JOHNSTON, A. W. Computational reconstruction of iron- and manganese-responsive transcriptional networks in alpha-proteobacteria. PLoS Comput. Biol., v. 2, p. e163, 2006.

RUTZ, J. M.; ABDULLAH, T.; SINGH, S. P.; KALVE, V. I.; KLEBBA, P. E. Evolution of the ferric enterobactin receptor in gram-negative bacteria. J. Bacteriol., v. 173, p. 5964-5974, 1991.

SAHA, R.; SAHA, N.; DONOFRIO, R. S.; BESTERVELT, L. L. Microbial siderophores: a mini review. J. Basic Microbiol., v. 53, p. 303-317, 2013.

SCHAIBLE, U. E.; KAUFMANN, S. H. Iron and microbial infection. Nat. Rev. Microbiol., v. 2, p. 946-953, 2004. 
SCHALK, I. J.; GUILLON, L. Fate of ferrisiderophores after import across bacterial outer membranes: different iron release strategies are observed in the cytoplasm or periplasm depending on the siderophore pathways. Amino Acids, v. 44, p. 1267-1277, 2013.

SCHMIDT, J. M.; STANIER, R. Y. The development of cellular stalks in bacteria. J. Cell Biol., v. 28, p. 423-436, 1966.

SCHONERT, S.; SEITZ, S.; KRAFFT, H.; FEUERBAUM, E. A.; ANDERNACH, I.; WITZ, G.; DAHL, M. K. Maltose and maltodextrin utilization by Bacillus subtilis. J. Bacteriol., v. 188, p. 3911-3922, 2006.

SCHRADER, J. M.; ZHOU, B.; LI, G. W.; LASKER, K.; CHILDERS, W. S.; WILLIAMS, B.; LONG, T.; CROSSON, S.; MCADAMS, H. H.; WEISSMAN, J. S.; SHAPIRO, L. The coding and noncoding architecture of the Caulobacter crescentus genome. PLoS Genet., v. 10, p. e1004463, 2014.

SHAPIRO, L.; MCADAMS, H. H.; LOSICK, R. Generating and exploiting polarity in bacteria. Science, v. 298, p. 1942-1946, 2002.

SHARFF, A. J.; RODSETH, L. E.; QUIOCHO, F. A. Refined 1.8-A structure reveals the mode of binding of beta-cyclodextrin to the maltodextrin binding protein. Biochemistry, $\mathrm{v}$. 32, p. 10553-10559, 1993.

SIMON, R.; PRIEFER, U.; PÜHLER, A. A broad host range mobilization system for in vivo genetic engineering: transposon mutagenesis in Gram negative bacteria. Biotechnology, v. 1, p. 784-790, 1983.

SKERKER, J. M.; LAUB, M. T. Cell-cycle progression and the generation of asymmetry in Caulobacter crescentus. Nat. Rev. Microbiol., v. 2, p. 325-337, 2004.

SMITH, G. A.; PORTNOY, D. A.; THERIOT, J. A. Asymmetric distribution of the Listeria monocytogenes ActA protein is required and sufficient to direct actin-based motility. Mol. Microbiol., v. 17, p. 945-951, 1995.

STIEFEL, A.; MAHREN, S.; OCHS, M.; SCHINDLER, P. T.; ENZ, S.; BRAUN, V. Control of the ferric citrate transport system of Escherichia coli: mutations in region 2.1 of the FecI extracytoplasmic-function sigma factor suppress mutations in the FecR transmembrane regulatory protein. J. Bacteriol., v. 183, p. 162-170, 2001.

STINTZI, A.; EVANS, K.; MEYER, J. M.; POOLE, K. Quorum-sensing and siderophore biosynthesis in Pseudomonas aeruginosa: lasR/lasI mutants exhibit reduced pyoverdine biosynthesis. FEMS Microbiol. Lett., v. 166, p. 341-345, 1998.

STOJILJKOVIC, I.; BAUMLER, A. J.; HANTKE, K. Fur regulon in gram-negative bacteria. Identification and characterization of new iron-regulated Escherichia coli genes by a fur titration assay. J. Mol. Biol., v. 236, p. 531-545, 1994.

SZEJTLI, J. Introduction and general overview of cyclodextrin chemistry. Chem. Rev., v. 98, p. 1743-1754, 1998. 
THOMAS-CHOLLIER, M.; SAND, O.; TURATSINZE, J. V.; JANKY, R.; DEFRANCE, M.; VERVISCH, E.; BROHEE, S.; VAN HELDEN, J. RSAT: regulatory sequence analysis tools. Nucleic Acids Res., v. 36, p. W119-127, 2008.

TOUATI, D. Transcriptional and posttranscriptional regulation of manganese superoxide dismutase biosynthesis in Escherichia coli, studied with operon and protein fusions. J. Bacteriol., v. 170, p. 2511-2520, 1988.

TOUATI, D. Iron and oxidative stress in bacteria. Arch. Biochem. Biophys., v. 373, p. 1-6, 2000.

TSENG, C. P. Regulation of fumarase (fumB) gene expression in Escherichia coli in response to oxygen, iron and heme availability: role of the $\operatorname{arcA}$, fur, and hemA gene products. FEMS Microbiol. Lett., v. 157, p. 67-72, 1997.

TSOKOS, C. G.; LAUB, M. T. Polarity and cell fate asymmetry in Caulobacter crescentus. Curr. Opin. Microbiol., v. 15, p. 744-750, 2012.

VASSINOVA, N.; KOZYREV, D. A method for direct cloning of fur-regulated genes: identification of seven new fur-regulated loci in Escherichia coli. Microbiology, v. 146 Pt 12, p. 3171-3182, 2000.

VIOLLIER, P. H.; SHAPIRO, L. Spatial complexity of mechanisms controlling a bacterial cell cycle. Curr. Opin. Microbiol., v. 7, p. 572-578, 2004.

VIOLLIER, P. H.; THANBICHLER, M.; MCGRATH, P. T.; WEST, L.; MEEWAN, M.; MCADAMS, H. H.; SHAPIRO, L. Rapid and sequential movement of individual chromosomal loci to specific subcellular locations during bacterial DNA replication. Proc. Natl. Acad. Sci. USA, v. 101, p. 9257-9262, 2004.

VISCA, P.; LEONI, L.; WILSON, M. J.; LAMONT, I. L. Iron transport and regulation, cell signalling and genomics: lessons from Escherichia coli and Pseudomonas. Mol. Microbiol., v. 45, p. 1177-1190, 2002.

WINKELMANN, G. Microbial siderophore-mediated transport. Biochem. Soc. Trans., v. 30, p. 691-696, 2002. 